\title{
Register of New Fruit and Nut Varieties
}

\author{
List 39
}

\author{
Edited by W.R. Okie \\ U.S. Department of Agriculture, Agricultural Research Service, Southeastern Fruit and Tree Nut Research \\ Laboratory, 21 Dunbar Road, Byron, GA 31008
}

Crop Listings': Apple, Apricot, Blackberry, Blueberry, Carambola, Cherry—Sweet, Currant, Gooseberry, Grape, Mango, Nectarine, Peach, Pear-Asian, Pear-European, Pear-Rootstock, Plum, Plumcot, Raspberry, Strawberry

\author{
APPLE \\ Robert A. Norton \\ AppleCorps, East Wenatchee, Wash. \\ Roger D. Way \\ New York State Agricultural Experiment Station \\ Geneva, N.Y.
}

Alkmene.-A high-quality, early-maturing apple adapted to cool, short-season areas. Origin: in Ahrensburg, Germany. Cox's Orange Pippin x Docteur Oldenburg. Fruit: medium, 200-300 gm, round, $25 \%$ to $50 \%$ red over yellow ground color, pin stripe; maturity similar to Gala's; flesh yellowish; crisp, juicy, medium firm, moderately acidic; storage life short -2 months at $0{ }^{\circ} \mathrm{C}$. Popular in northern Europe, but not grown commercially in the United States.

Anderson Red Delicious.-A spur-type strain assigned to Yakima Valley Nursery, Yakima, Wash. Origin: A sport of Redchief ${ }^{\circledR}$ Delicious. Not patented. Fruit: very early coloring, solid red blush; matures earlier than some Delicious strains.

ArkCharm.-An early-ripening apple bred for the South. Origin: Apple breeding program, Univ. of Arkansas, Fayetteville (Rom and Moore); tested as AA18; introd. in 1993. Fruit: large, blotchy red; ripens just before Jerseymac and Paulared; tart, good quality. Storage life short.

Aurora.-See Joburn ${ }^{\mathrm{TM}}$ Braeburn.

Baigent.-See Brookfield ${ }^{\mathrm{TM}}$ Gala.

Beni Shogun (Heisei Fuji)._A red sport of Yataka Fuji. Origin: limb sport of Yataka discovered by R. Yahagi; Japan Patent 3159, 1989 by Nakajima Tenkoen Co., Ltd., Yamagata, Japan. U.S. rights assigned to ProTree Nursery, Brentwood, Calif. USPP ${ }^{2}$ 7997. Fruit: blushed orange-red overall; ripens with Senshu, 4 weeks before Fuji, 1 week before Red Delicious; quality very similar to standard Fuji, but storage life is shorter. Tree: identical to standard Fuji.

Big Red Gala.-A Gala type with larger fruit. Origin: limb sport of Gala, discovered by Tina Fackler, Rocky Mountain Nursery, New Salisbury, Ind., in 1992. Assigned to ProTree Nurseries, Brentwood, Calif. USPP 10458. Fruit: similar to Gala, except 30\% to $40 \%$ larger, with higher flesh density. Color similar to Gala (Kidd's D8). Tree: identical to Gala.

Bolero.-See Stark ${ }^{\circledR}$ Emerald Spire ${ }^{\circledR}$.

Brock.-A McIntosh-type apple that matures slightly later and hangs better on the tree. Origin: Golden Delicious $x$ McIntosh, developed by Russ Bailey at Univ. of Maine; introd. in 1966. Tested as Me. 7-492. Named after Henry Brock of Alfred, Maine, who first tested the apple. Fruit: similar in shape to McIntosh but slightly larger, better flavor, and with nonoxidizing flesh. Color primarily creamy yellow with variable pink blush. Tree: similar to McIntosh, with tendency to biennial bearing.

Brookfield ${ }^{\mathrm{TM}}$ Gala (Baigent).-An improved striped Gala. Origin: Paul Brookfield, Hawkes Bay, New Zealand. Bud mutation of Royal Gala found in 1994. Assigned to Willow Drive Nursery, Ephrata, Wash. USPP 10016. Fruit: typical Gala in size and shape, but with a very prominent red stripe over a lighter red background color. Harvested in two picks.

\footnotetext{
${ }^{1}$ Thanks to the crop editors for compiling this information. Individuals with varieties to describe should contact the crop editors directly. Individuals willing to serve as crop editors should contact W.R.O.

${ }^{2}$ USPP $=$ U.S. Plant Patent. USPPAF = U.S. Plant Patent Applied For.
}

Buckeye $^{\mathrm{TM}}$ Gala (Simmons, Peace Valley 1001, PV1001).- -New Gala sport coloring earlier than its parent, Imperial Gala. Origin: limb mutation of Imperial Gala found near Salem, Ohio, in 1989. Assigned to International Plant Management, Lawrence, Mich. USPPAF. Fruit: similar to Imperial in all but color, which develops 3-4 weeks earlier and ripens 5-7 days earlier; becomes $100 \%$ solid red at maturity, allowing reduced number of harvests. Tree: same as Imperial.

Caitlin.-See Stark ${ }^{\circledR}$ GrandGala.

Charlotte.-See Stark ${ }^{\circledR}$ Irish Spire ${ }^{\circledR}$.

Crimson $^{\mathrm{TM}}$ Jonagold (Romagold).- -A red mutation of Jonagold. Origin: a limb mutation of Jonagold, discovered by Romain Surkijn in Belgium, 1983. Assigned to Brandt's Fruit Trees, Parker, Wash. USPP 9541. Fruit: similar to Jonagold in shape and size, but has cherry red, striped pattern over majority of fruit surface; quality identical to Jonagold. Tree: similar to Jonagold.

Crimson $^{\mathrm{TM}}$ Gala (Waliser).- - A red-fruited mutation of Royal Gala. Origin: introd. in 1992. Assigned to Brandt Fruit Trees, Parker, Wash. USPP 8673. Fruit: deeper red color than Royal Gala, slight pin stripes, colors 5-7 days earlier; fewer pickings are needed. Flesh is firm, crisp textured, white with a yellowish tinge. Otherwise similar to Gala. Tree: similar to Gala.

Elliott (Timp-Gold).-Yellow apple with pink blush, similar to Golden Delicious. Origin: chance seedling discovered by Grant Eliott in Provo, Utah, in the early 1990s. Assigned to Burchell Nursery, Oakdale, Calif. USPPAF. Fruit: similar to Golden Delicious, except exposed fruits generally have pink blush; flesh is white, crisp, juicy, sweet/tart; ripens with Red Delicious; not prone to russet.

Flamenco.-See Stark ${ }^{\circledR}$ Crimson Spire ${ }^{\circledR}$.

Fuji-Spike (Lynd-Spur)._A spur-type Fuji. Origin: whole tree mutation of standard Fuji, discovered by Mitch Lynd, Johnstown, Ohio, in the early 1990s. USPP 9508. Fruit: similar to standard Fuji, ripens mid-October. Tree: very compact, precocious and easier to manage than nonspur types. Precise thinning necessary to prevent biennial bearing.

Gale Gala ${ }^{\mathrm{TM}}$ (Malaga).-A full-colored Gala capable of being harvested in one or two picks. Origin: Malaga, Wash., discovered by Wally Gale in 1990. Introd. in 1996 by Van Well Nursery, Wenatchee, Wash. Whole tree sport of Royal Gala. USPP 10114. Fruit: identical to Royal Gala except for dark stripes over bright red under-color. Tree: similar to Royal Gala.

Gold Nugget.-An early-ripening, yellow apple. Origin: discovered about 1994 by Danny Johnson, Bedford, Va. Fruit: ripens early August and hangs on tree 60 days after ripening; medium-to-large size (2-1/2 to 3-1/4 inches); skin golden color with very slight blush, smooth with no russet unlike neighboring Golden Delicious; flesh resists bruising; flavor sweet, with satisfying aftertaste. Storage life similar to that of Delicious- 60 days at $40{ }^{\circ} \mathrm{F}$, without shriveling or loss of flavor.

Hartencourt.-See Royal Court.

Heinicke.-See Redchief ${ }^{\circledR}$ Delicious.

Heisei Fuji.-See Beni Shogun.

Hercules.—See Stark ${ }^{\circledR}$ Irish Spire ${ }^{\circledR}$.

$\mathbf{I t}^{\circledR}$ Delicious.-A limb sport of Redchief ${ }^{\circledR}$ Delicious. Origin: discovered in the mid-1980s by Don Heinicke, Wenatchee, Wash. Assigned to Willow Drive Nursery, Ephrata, Wash. Fruit: finer stripe and earlier coloring than Redchief; flavor the same as Redchief.

Jackson.-See Ruby Jon. 
Joburn $^{\mathrm{TM}}$ Braeburn (Aurora).-Striped strain of Braeburn. Origin: Hawkes Bay, New Zealand; named Aurora there. A mutation of standard Braeburn. Assigned to Willow Drive Nursery, Ephrata, Wash. USPPAF. Fruit: skin more heavily striped than Braeburn; flesh lower in acidity. Tree: lower vigor, more spreading, heavier cropping than Braeburn.

Jonathan TF-812.—See Lucky Jon ${ }^{\circledR}$.

Jubilee Fuji (Van Leuven)._-An early-maturing Fuji strain. Origin: found in 1992 at Broetje Orchards, Prescott, Wash. Assigned to C\&O Nursery, Wenatchee, Wash. USPPAF. Fruit: similar in size and shape to standard Fuji. Overall pinkish red blush skin color over green to yellow background. Fruit ripens $30-40$ days before standard Fuji, at least 1 week earlier than Red Delicious. Sugar content and firmness similar to standard Fuji's when mature. Keeps up to 5 months in CA storage. Tree: identical to standard Fuji.

Kiddle.-See Stark ${ }^{\circledR}$ Galaxy Gala.

Lochbuie $^{\mathrm{TM}}$ Braeburn.-A recently released sport of Braeburn. Origin: New Zealand; assigned to Willow Drive Nursery, Ephrata, Wash. USPPAF. Fruit: $90 \%$ to $100 \%$ solid red color; otherwise similar to standard Braeburn. Can be harvested in one or two pickings. Tree: identical to standard Braeburn.

Lucky Rose Golden.-A scarlet-blushed, yellow apple. Origin: chance seedling discovered about 1991 at Lucky Badger Orchard, Orondo, Wash. USPP 9707. Fruit: skin very attractive, with one-third scarlet blush pink cheek on sunny side; ground color whiter than Golden Delicious; exceptionally smooth finish, small lenticels. Stem is short; flesh slightly less firm than Golden Delicious, flavor more tart. Harvest season 1 week before Golden Delicious.

Lucky Jon $^{\circledR}$ (Jonathan TF-812). - Red-fruited mutation of Nured Jonathan. Origin: discovered in 1986 at Thome Farms, Comstock Park, Mich. Tested as TF-812. Assigned to Hilltop Nurseries, Hartford, Mich. USPP 8701. Fruit: dark red blush over $80 \%$ to $95 \%$ of fruit surface.

Lydia's ${ }^{\circledR}$ Red Gala._-An early-ripening blushed Gala. Origin: unknown; propagated by Hilltop Nurseries, Hartford, Mich. Fruit: blush type, $80 \%$ to $100 \%$ orange-red; ripens 3-4 days ahead of Fulford Gala. Tree: same as Gala.

Lynd-Spur.-See Fuji-Spike.

Malaga.-See Gale Gala.

Midnight $^{\mathrm{TM}}$ Spur Delicious.-A solid red-fruited, early coloring mutation of Oregon Spur Delicious. Origin: introd. about 1993 by Columbia Basin Nursery, Quincy, Wash.

MonArk.-A high-quality, early-ripening apple. Origin: breeding program of Rom and Rom, Univ. of Arkansas, Fayetteville; tested as AA44; introd. in 1993. USPPAF. Fruit: large to very large; red to red striped; shape is round. Flesh very firm for an early variety, tart. Harvests early July; storage life long, 3-4 months at $-0.5^{\circ} \mathrm{C}$. Tree: vigorous, spreading; very precocious, annually productive.

Myra Red Fuji.-Early-ripening mutation of Fuji. Origin: discovered about 1992 by Myles Van Leuven, Prescott, Wash. Assigned to C\&O Nursery, Wenatchee, Wash. USPP 9645. Fruit: size medium to large, with striped color pattern and a bright, pinkish red finish; flesh firm, light creamy yellow, with high soluble solids and good storage life; ripens 3-4 weeks before standard Fuji.

Obelisk.-See Stark ${ }^{\circledR}$ Crimson Spire ${ }^{\circledR}$.

Obrogala.-See Stark ${ }^{\circledR}$ UltraRed $^{\mathrm{TM}}$ Gala.

Olsentwo.-See Pacific Gala ${ }^{\mathrm{TM}}$.

Pacific GalaTM (Olsentwo).-A fully coloring mutation of Royal Gala. Origin: discovered in 1989 as a whole-tree mutation of Stark ${ }^{\circledR}$ UltraRed $^{\mathrm{TM}}$ Gala by Dick and Larry Olsen, Benton City, Wash. USPP 9681. Fruit: high color on $90 \%$ to $100 \%$ of fruit. Less cracking, firmer flesh, and better storage quality than Gala. Tree: same as Gala.

Peace Valley 1001.-See Buckeye ${ }^{\mathrm{TM}}$ Gala.

Pinova $^{\mathrm{TM}}$.- New hybrid from Germany becoming widely marketed in Europe. Origin: Institute of Fruit Research, Dresden-Pillnitz, Germany, cross of [Duchess of Oldenburg x Cox's Orange Pippin] X Golden Delicious by Murawski, Schmadlak, Fischer, and Fischer. Introd. in 1986. Licensed to Tree Connection, Dundee, Ore. USPPAF. Fruit: medium size, conical, pinkish red blush over yellow background, ripening with Golden Delicious; flesh cream colored, firm, fine grained; sweet-tart flavor somewhat similar to that of Golden
Delicious; storage life better than that of Golden Delicious. Tree: medium to low vigor, very productive, diploid, hardy, precocious.

Polka.-See Stark ${ }^{\circledR}$ Scarlet Spire ${ }^{\circledR}$.

PV 1001.-See Buckeye ${ }^{\mathrm{TM}}$ Gala.

Radiant $^{\mathrm{TM}}$ Spur Delicious.-An early coloring, solid-blush mutation of the Ace $^{\circledR}$ Spur Delicious. Origin: introd. about 1993 by Columbia Basin Nursery, Quincy, Wash.

Redchief ${ }^{\circledast}$ Delicious (Heinicke). - A red-fruited mutation of Delicious. Origin: discovered by Don Heinicke, Wenatchee, Wash. Fruit: superior striping, high color factor, quality flesh and flavor.

Redcort $^{\circledR}$.- Early coloring, full red mutation of Cortland. Origin: Hudson Valley, N.Y., in the mid-1980s. Assigned to Hilltop Nurseries, Hartford, Mich. USPP 5095. Fruit: similar to Cortland, except that it colors 2 weeks before maturity to $90 \%$ full red. Tree: same as Cortland.

Redmax (Starling)._A red-fruited mutation of McIntosh. Origin: introd. in 1990, assigned to Hilltop Nurseries, Hartford, Mich. USPP 7167. Fruit: Early coloring allows for more concentrated harvest with less fruit drop.

Redwinter ${ }^{\circledR}$.-New Jersey-bred apple adapted to France. Origin: introd. by L.F. Hough, Rutgers Univ., New Brunswick, N.J. Tested as NJ92 by Demol Nursery in France. Fruit: usually solid red blush, conspicuous lenticels; firm flesh, very good eating quality; long storage life. Tree: good vigor, midseason bloom, good productivity.

Romagold.-See Crimson ${ }^{\mathrm{TM}}$ Jonagold.

Royal Court (Hartencourt).-Limb sport of Cortland. Origin: discovered by Jacob A. Hartenhof, Waterville Nova Scotia, Canada. Assigned to Adams County Nursery, Aspers, Pa. USPP 10049. Fruit: similar to Cortland, except earlier, with a much higher solid blush skin color. Tree: same as Cortland.

Ruby Jon (Jackson).—Red mutation of Jonathan. Origin: limb sport of Jonnee, found in Bowling Green, Ky. Assigned to International Plant Management, Lawrence, Mich. USPP 10115. Fruit: $100 \%$ solid red blush, early coloring; otherwise similar to Jonathan. Tree: same as Jonathan.

Schlect Spur Delicious._-An early-coloring mutation of Delicious. Origin: found in a block of spur Delicious in Yakima, Wash. Assigned to C\&O Nursery, Wenatchee, Wash. Fruit: full color in midAugust, much earlier than other Delicious strains.

Simmons.-See Buckeye ${ }^{\mathrm{TM}}$ Gala.

Sommerfeld.-High-quality dessert apple similar, if not identical, to the Japanese cultivar Senshu. Origin: possible seedling growing at Sommerfeld residence near Modesto, Calif.; discovered about 1989, assigned to Green Tree Nursery, La Grange, Calif. USPP 8234. Fruit: medium size, very short stem, very shallow, puckered basin, very thin skin, reddish blush and stripe, rather dull finish; ripens between Gala and Red Delicious; excellent low-acid flesh, tender and juicy; tends to crack around stem when fully mature; an excellent roadside market apple, but too tender to handle in large volume; fair storage quality to January-February at $0^{\circ} \mathrm{C}$.

Stark $^{\circledR}$ Crimson Spire $^{\circledR}$ (Flamenco, Obelisk).-Columnar-type tree derived from cross with Wijcik McIntosh. Origin: East Malling Research Station (England) breeding program, English name Flamenco. Assigned to Stark Bros., Louisiana, Mo. USPP 9060. Fruit: dark red skin, white flesh, crisp and tangy; shape round-oblate; good for fresh eating; ripens in mid-September in Missouri. Tree: very compact, erect, rigid; leaves large, wide, green; close internodes, many spurs, tendency to biennial bearing.

Stark $^{\circledR}$ Emerald Spire ${ }^{\circledR}$ (Bolero, Tuscan $)$.-Columnar-type tree derived from cross with Wijcik McIntosh. Origin: East Malling Research Station (England); English name Bolero. Assigned to Stark Bros., Louisiana, Mo. USPP 6225. Fruit: skin yellow-green, with $25 \%$ pale orange blush; flesh cream; size 3 inches, oblate; flavor tart; ripens early September in Missouri. Tree: very compact, erect, rigid, close internodes, many spurs.

Stark $^{\circledR}$ Galaxy Gala (Kiddle).-A red-fruit mutation of Royal Gala. Origin: Hawkes Bay, New Zealand (Kiddle and McKenzie), 1989. Assigned to Stark Bros., Louisiana, Mo. USPP 6955. Fruit: similar to Royal Gala but with higher color and more prominent stripe pattern. Color pattern unstable in some locations. Tree: similar to Royal Gala. 
Stark $^{\circledR}$ GrandGala (Caitlin)._-A limb sport of Stark ${ }^{\circledR}$ Royal Gala. Origin: discovered in 1992 by Charles McSpadden, Cleveland, Tenn. USPPAF. Fruit: size about $1 / 4$ inch larger in diameter and $25 \%$ to $30 \%$ heavier in weight than Royal Gala; color same as Royal Gala; ripens 3 days earlier. Tree: leaves and stems noticeably thicker than those of Royal Gala.

Stark $^{\circledR}$ Irish Spire ${ }^{\circledR}$ (Charlotte, Hercules).-Columnar-type tree derived from cross with Wijcik McIntosh. Origin: East Malling Research Station (England); English name Charlotte. Assigned to Stark Bros., Louisiana, Mo. USPP 9061. Fruit: skin green with red blush; flesh cream; size large; shape round-conical; ripe early to midSeptember. Primary use is for cooking. Tree: similar to Wijcik, compact, erect, many spurs.

Stark $^{\circledR}$ Scarlet Spire ${ }^{\circledR}$ (Polka, Trajan).-Columnar-type tree derived from cross with Wijcik McIntosh. Origin: East Malling Research Station (England); English name. Assigned to Stark Bros., Louisiana, Mo. USPP 6226. Fruit: red skin $20 \%$ to $30 \%$ over yellow/ green ground color; flesh greenish; medium size; ripens early to midSeptember in Missouri; moderately juicy, spicy; conical shape. Tree: very compact, erect, rigid; close internodes, many spurs. Tendency to biennial bearing.

Stark $^{\circledR}$ UltraRed $^{\mathrm{TM}}$ Gala $($ Obrogala $)$.- -A red-fruited mutation of Gala. Origin: introd. about 1992. Stark Bros., Louisiana, Mo. Fruit: fully colored, lightly striped with a darker red hue than Royal Gala; consistent red color throughout the tree; flesh texture similar to Gala. Harvested several days earlier than Royal Gala; otherwise, the fruit and tree are identical to Gala.

Stark $^{\circledR}$ Ultra Spire ${ }^{\circledR}$ (Telamon, Waltz).-Columnar-type tree derived from cross with Wijcik McIntosh. Origin: East Malling Research Station (England); English name Waltz. Assigned to Stark Bros., Louisiana, Mo. USPP 6224. Fruit: red skin 50\% over yellowgreen; flesh cream; medium size; round-conical shape; juicy, with tart flavor; ripens mid-September in Missouri. Tree: the most compact of the columnar-type trees yet released.

Starling.-See Redmax.

Stellar.-A very firm, conical yellow apple. Origin: introd. in 1993 from the apple breeding program of Rom and Rom, Univ. of Arkansas, Fayetteville. USPPAF. Fruit: yellow, sometimes with orange blush; large, uniformly conic; skin smooth. Flesh is very firm, light yellow, crisp and tart-sweet. Fruit hangs well to the tree after it matures. Harvest season is 2 weeks after Delicious; storage life at 0.5 ${ }^{\circ} \mathrm{C}$ for more than 4 months. Tree: very vigorous, slightly upright, productive.

Sun Fuji ${ }^{\mathrm{TM}}$.- - Red-fruited mutation of Fuji. Origin: mutation of standard Fuji discovered by Henry Sanguinetti, Lodi, Calif., in the mid-1990s. Fruit: earlier and more intense coloring than the parent; stripe and blush pattern. Tree: identical to standard Fuji.

T.A.C.-114.-See Treco ${ }^{\circledR}$ Red Fuji.

Telamon.-See Stark ${ }^{\circledR}$ Ultra Spire ${ }^{\circledR}$.

Timp-Gold.-See Elliott.

Trajan.-See Stark ${ }^{\circledR}$ Scarlet Spire ${ }^{\circledR}$.

Treco $^{\circledR}$ Red Fuji (T.A.C.-114).—Early-ripening Fuji strain. Origin: limb mutation of BC 2 Fuji (strain originally from Morioka, Japan), discovered by Cal Cooper, Brewster, Wash. Fruit: colors and ripens 4-6 days earlier than BC 2; blush and stripe pattern over $80 \%$ to $95 \%$ of surface. Tree: identical to standard Fuji.

Tropic Sweet.-New, low-chill apple adapted to subtropical climates with mild winters. Origin: Univ. of Florida, Gainesville, Wayne B. Sherman, breeder; cross of (NJ38 x Anna) $F_{2}$, rel. 1996. Tested as Fla. 90-3. USPP 9708, assigned to Fla. Foundation Seed Producers, Greenwood, Fla. Fruit: firmer, much sweeter and lower acid compared to Anna; shape round-conic. Tree: semi-spreading and semi-spur habit.

Tuscan.-See Stark ${ }^{\circledR}$ Emerald Spire ${ }^{\circledR}$.

Twin Bee ${ }^{\mathrm{TM}}$ Gala.-Early, high-colored Gala. Origin: limb sport of Royal Gala, discovered in Michigan. Assigned to Hilltop Nurseries, Hartford, Mich. USPPAF. Fruit: red-orange 90\% to 100\%, with prominent stripe; matures $7-10$ days earlier than Royal. Tree: same as Gala.

Van Leuven.-See Jubilee Fuji.

Waliser.-See Crimson ${ }^{\mathrm{TM}}$ Gala.
Waltz.-See Stark ${ }^{\circledR}$ Ultra Spire $^{\circledR}$.

Washington Spur ${ }^{\mathrm{TM}}$ (Wittkopf).- - A mutation of Oregon Spur Delicious. Origin: discovered in 1979 as a limb mutation of Oregon Spur in Kennewick, Wash. Introd. in mid-1980s by Carleton Nursery, Dundee, Ore.; sublicensed to Willow Drive Nursery, Ephrata, Wash. Fruit: full-color, striped, early coloring strain. Tree: typical spur-type Delicious.

Wittkopf.-See Washington Spur ${ }^{\mathrm{TM}}$.

Zesta $^{\mathrm{TM}}$-—New, early-ripening cultivar from Univ. of Minnesota. Origin: introd. in 1998 by Univ. of Minnesota. A cross of State Fair x MN 1691; tested as MN 1824. USPPAF. Fruit: 50\% to 85\% red stripe over yellow; average 3-inch fruit; white flesh; crisp, juicy texture; good sugar : acid balance; ripens with Paulared. Stores $\approx 7$ weeks at $32^{\circ} \mathrm{F}$. Tree: hardy to $-25^{\circ} \mathrm{F}$; vigorous, susceptible to scab.

\section{APRICOT}

\section{Craig A. Ledbetter}

Agricultural Research Service, Fresno, Calif.

Improved Honeycot ${ }^{\mathrm{TM}}$.-See Suapriseven.

Late Honeycot ${ }^{\mathrm{TM}}$.-See Suaprieight.

Lorna.-A large, early-season apricot for the fresh market. Origin: in Fresno, Calif., by USDA-ARS. Sel. in 1987 from an openpollinated population of selection K33-81; tested as K505-50; introd. in 1998. Fruit: elliptic; freestone; solid orange color; firm and finetextured flesh; somewhat susceptible to rain cracking. Tree: a markedly open and spreading growth habit; self-compatible flowers; fruit set is primarily on terminals of one-year-old shoots; probably graft incompatible with Marianna 2624 rootstock.

Robada.-A highly colored midseason apricot for the fresh market. Origin: in Fresno, Calif., by USDA-ARS. Sel. in 1987 from the cross Orangered X K113-40; tested as K106-2; introd. in 1997; USPP 9890. Fruit: oblong with slightly compressed cheeks; deep orange coloration with a strong red blush on sun-exposed surfaces; freestone; aromatic and sweet at harvest maturity. Tree: vigorous and erect growth habit; self-compatible flowers; sweet kernel; heterozygous for male-sterility.

Suaprieight (Late Honeycot ${ }^{\mathrm{TM}}$ ). - A deep orange apricot adapted to lower chilling. Origin: in Wasco, Calif., by Carlos D. Fear, Bruce D. Mowrey, and David W. Cain. Sel. in 1990 from the cross Suapritwo x 066-245; tested as 90A-030; introd. in 1996; USPP 10232 assigned to Sun World Inc. Fruit: ripens about with Patterson; very large fruit averaging $138 \mathrm{~g}$; firm, deep orange flesh with excellent eating quality; $40 \%$ red over yellow-orange ground color. Tree: large spreading growth habit; self-compatible flowers; consistent cropping even in years when most varieties exhibit lack of chill symptoms.

Suapriseven (Improved Honeycot ${ }^{\mathrm{TM}}$ ). - An early apricot adapted to lower chilling. Origin: in Wasco, Calif., by Carlos D. Fear, Bruce D. Mowrey, and David W. Cain. Sel. in 1990 from the cross Suapritwo XF18; tested as 90A-010; introd. in 1996; USPP 10165 assigned to Sun World Inc. Fruit: early midseason maturity with Suapritwo; firm, deep orange flesh with excellent eating quality; $60 \%$ bright red over deep orange ground color; $110 \mathrm{~g}$. Tree: large spreading growth habit; self-compatible flowers; consistent bearer in years when Castlebrite and Katy show lack of chill symptoms.

\section{BLACKBERRY AND HYBRID BERRIES}

\section{John R. Clark \\ Univ. of Arkansas, Fayetteville \\ Chad E. Finn \\ USDA-ARS, Northwest Center for Small Fruit Research Corvallis, Ore.}

Cacak Thornless.-See Cacanska bestrna.

Cacanska bestrna (Cacak Thornless).-Spinefree, productive, semi-erect blackberry with excellent fruit quality, disease resistance and winter hardiness. Origin: in Belgrade,Serbia, by M. Stanisavljevi $\ddot{Y}$ (Agr. Res. Inst.-Serbia). Dirksen x Black Satin; cross made in 1984; selected in 1987; tested as 1/III/87. Fruit: ripens midseason with a short harvest season; very large (average $9.3 \mathrm{~g}$ but up to $15.0 \mathrm{~g}$ ); glossy 
black; long cylinder shape; sweet and aromatic; firm; easily picked. Plant: very vigorous, strong canes; spineless; winter tolerant; resistant to Kuehneola uredinsis.

Cowley.-A very early, productive blackberry with strong, spiny canes that is adapted to the Rio Grande Valley. Origin: in Monte Alto, Tex., by A.W. Scott, Jr. and M.J. Lukefahr, Rio Farms. Uncertain origin. Fruit: larger than Brazos, Rosborough, Cherokee, Choctaw, and Cheyenne in Monte Alto; rated acceptable based on flavor, color, appearance, and texture. Plant: extremely vigorous; produces shoots freely from root cuttings; more erect than Brazos and less erect than Cherokee; similar thorniness to Brazos; better adapted to highly alkaline ( $\mathrm{pH} 7.8$ ), calcareous soil than most cultivars; very productive.

Cox's Miracle Berry.-An erect to semi-erect, thornless blackberry with extended cropping capability. Origin: in Pineville, W.Va., by Mason E. Cox. Parentage unknown. USPP 6105; 16 Feb. 1988. Fruit: round; length of 2.5 to $3.2 \mathrm{~cm}$; glossy black; berries borne in clusters; seeds medium-large; produces two crops, one crop beginning ripening 10 July and the second 1 Sept. Plant: thornless; erect to semierect canes growing 1.0 to $1.3 \mathrm{~m}$ in height; second crop of fruit produced on shoots that develop at the base of fruiting canes; has withstood $-18{ }^{\circ} \mathrm{C}$ without winter injury; relatively disease resistant.

Doyle's Blackberry.-A semi-erect, productive, thornless blackberry that resembles a wild blackberry. Origin: in Washington, Ind., by Thomas E. Doyle. USPP 4094; 23 Aug. 1977. Unknown parentage; discovered in Mr. Doyle's berry patch in 1970; introd. in 1977. Fruit: round; length of 1.9 to $2.9 \mathrm{~cm}$; borne on clusters of 20 to 100 berries; fluorescent blue-black appearance; ripens over an extended period (60 days); taste similar to that of wild blackberries; maintains firmness several days following harvest. Plant: thornless, semi-erect; very large canes 2.5 to $3.8 \mathrm{~cm}$ diameter that produce long, trailing laterals; very productive yielding 38 to $76 \mathrm{~L} /$ plant of fruit; disease resistant; has withstood temperatures of $-20.5^{\circ} \mathrm{C}$.

Everthornless.-Trailing, thornless blackberry that is a somaclonal variant of Thornless Evergreen. Origin: in Champaign, Ill., by Kenneth McPheeters and Robert Skirvin, Univ. of Illinois. USPP 9407; 26 Dec. 1995; assigned to Research Corporation Technologies. Somaclonal variant (nonchimeral) of Thornless Evergreen. Fruit: somewhat coni$\mathrm{cal} ; 3.5 \mathrm{~g}$; seed weight $3.3 \mathrm{mg}$; medium firmness; very good flavor, mildly acid; $14.5 \%$ soluble solids; comparable processed quality to Thornless Evergreen; ripens beginning in mid-August in Aurora, Ore. Plant: thornless; produces thornless root suckers; trailing; primocanes $3.0 \mathrm{~m}$ in length; petioles bent, a trait differentiating Everthornless from Thornless Evergreen; appears to be more hardy than Thornless Evergreen.

Exel's Everbearing Blackberry.-An erect to semi-erect, everbearing blackberry. Origin: in Green Forest. Ark., by Exel R. Smith. USPP 6101; 9 Feb. 1988. Thornfree x "treeform" blackberry. Fruit: usually more than $2.5 \mathrm{~cm}$ in length; sweet; soft, undeveloped seeds; ripens in latter part of June until the middle of October. Plant: primocanes near erect; retains some leaves during dormancy.

Helen.-A very early-ripening, genetically spineless, trailing blackberry with excellent fruit quality. Origin: in Kent, England, by D.L. Jennings, Medway Fruits. Silvan X unnamed seedling; introd. in 1997. World-wide marketing rights held by Meiosis Ltd., West Malling, Kent. Fruit: size between 6.0 and $6.5 \mathrm{~g}$; bright; uniform appearance; conic; firm texture; moderate skin strength; suitable for fresh market; similar to Adrienne but 5 days earlier ripening. Plant: stout but canes less vigorous than Adrienne; fruiting laterals short and stout.

Orkan.-A high-yielding, genetically spineless blackberry with greater cold hardiness than Black Satin. Origin: in Brzezna, Poland, by J. Danek, Polish Research Institute of Pomology and Floriculture. Black Satin x No. 79411 (Ark. 1084 OP); cross made in 1983. Fruit: larger than Black Satin (5.5 g); long; black; bright; firm; good skin strength; acid flavor; ripens ahead of Black Satin; fruit more susceptible to Botrytis cinerea than Black Satin under wet conditions. Plant: spineless; similar to Black Satin but with shorter and more erect canes; fruiting laterals are medium length and strong.

Per Can.-A hardy, thornless, trailing blackberry. Origin: in Laval, Quebec, Canada, by Tony Huber. USPP 7251; 19 June 1990; assigned to W.H. Perron et Cie. Ltee. Developed from a wild selection of Rubus canadensis selected on the Appalachian Plateau in southern Quebec. Fruit: round to slightly conical; length $\approx 30 \mathrm{~mm}$; average weight $4.5 \mathrm{~g}$; dark black at maturity; $9.1 \%$ soluble solids; excellent flavor described as slightly acid/slightly sugary; ripens mid-July to late October. Plant: thornless; trailing; vigorous; must be propagated by tip cuttings or tissue culture since it does not sucker from root cuttings; resistant to cold to $-40^{\circ} \mathrm{C}$.

Siskiyou.-A trailing, early-ripening, large-fruited, high-quality blackberry for fresh market or processing. Origin: in Corvallis, Ore., by C.E. Finn, F.J. Lawrence, B.C. Strik, J. DeFrancesco, and B. Yorgey, USDA-ARS, Oregon State Univ. and Wash. State Univ. ORUS 2027 (Olallie x ORUS 1367) x ORUS 1826 (ORUS 1122 x Boysen); selected in 1983; introd. in 1997; tested as ORUS 830-4. Fruit: very large ( 8.0 to $9.0 \mathrm{~g}$ ); firm; attractive with a high drupelet count; excellent flavor; ripens 10-14 days before Marion; tips of fruit on late flowers often do not set; lower soluble solids than Waldo but similar to Marion; $\mathrm{pH}$ slightly higher and titratable acidity slightly lower than Marion; IQF fruit similar to Marion for color characteristics, flavor and perception of "seediness"; purée nearly indistinguishable from Marion, similar for overall quality, aroma, flavor, and appearance, although perceived to have a poorer color; juice similar in color, appearance, aroma and flavor to Marion. Commercially has been excellent for fresh-market in California and Oregon. Plant: vigorous; more spines than Marion; more tolerant of environmental stress (i.e., low temperature) than Marion; canes more resistant to cane and leaf spot (Septoria rubi) than Marion; cane botrytis (Botrytis cinerea) has been observed occasionally; has shown no symptoms of yellow rust (Kuehneola uredinis) infection or of the unidentified pathogen that caused drupelets of Kotata and Marion to turn brown and dry in 1997 and 1998.

\section{BLUEBERRY}

\section{Paul Lyrene \\ Horticultural Sciences Dept., Univ. of Florida, Gainesville Mark Ehlenfeldt Blueberry and Cranberry Research Laboratory Chatsworth, N.J.}

Biloxi.-A vigorous and productive southern highbush blueberry. Origin: USDA Small Fruit Research Station, Poplarville, Miss. Sharpblue $x$ US329. Tested as MS318. An interspecific hybrid containing $V$. corymbosum, V. darrowi, and other species. Selected in 1986 in southern Mississippi by J.M. Spiers, C.L. Gupton, and A.D. Draper. Introd. in 1998. Berry: medium size, good color, flavor, and firmness, with small picking scar. Flowers and ripens early. Plant: vigorous, productive, upright growth habit. Should be interplanted with other southern highbush cultivars for cross-pollination. Relatively low chilling requirement; adapted to coastal plain areas of southeastern U.S.

Bluecrisp (Crunchyblue)._A southern highbush blueberry with unusually firm texture. Origin: Univ. of Florida, Gainesville. USPPAF. A complex hybrid between $V$. corymbosum and $V$. darrowi. Tested as FL84-40. Sel. in 1982; released in 1998. Berry: early ripening, very firm, good scar and flavor. Size medium to large, color dark blue. Plant: upright; medium vigor; chilling requirement $\approx 500 \mathrm{~h}$. Somewhat susceptible to blueberry bud mite.

Crunchyblue.-See Bluecrisp.

Duplin.-A southern highbush blueberry with high fruit quality. Origin: Castle Hayne, N.C. From the cross 290-1 x G-156 made by Arlen Draper. Sel. in 1978; introd. in 1998. Berry: large, blue, firm, good picking scar and good flavor. Plant: high-yielding, semi-upright, high vigor (similar to Croatan). Blooms and ripens with or slightly later than Croatan. Not self-fruitful. Tolerant or resistant to Botryosphaeria dothidea. Propagation rights assigned to Finch Nursery, Bailey, N.C.

Echota.-A self-fruitful highbush blueberry with excellent flavor and shelf life. Origin: North Carolina State Univ. From the cross E66 x NC683 made by G.J. Galletta. Introd. in 1998. Berry: large, very light blue, good flavor, excellent picking scar, good firmness. High acidity and excellent shelf life. Plant: vigorous, semi-upright. Consis- 
tently productive, self-fruitful, late-midseason ripening. Appears to be well adapted to the highlands of western North Carolina. Propagation rights assigned to Finch Nursery, Bailey, N.C.

Emil.-A half-high blueberry with good winterhardiness. Origin: at Balsgard-The Swedish Univ. of Agr. Sci. as a seedling from BV838 open pollinated. Introd. in 1997. Berry: small, good flavor and firmness. Dark blue, medium scar. Plant: moderately upright; good winterhardiness; productive as Northblue.

Friendship.-A highly productive half-high blueberry. Origin: Originated from open-pollinated seed collected from a $V$. corymbosum population near Friendship, in Adams County, Wis. (lat. $44^{\circ}$ ). Appears to be a hybrid with $V$. angustifolium. Sel. in 1982. Introd. in 1990. Berry: weight $\approx 0.6 \mathrm{~g}$. Flavor mild subacid and sweet when fully mature; color sky blue. Similar in firmness to Northcountry; probably not suitable for machine harvest. Plant: half-high; $\approx 0.8 \mathrm{~m}$ tall after 8 years in Wisconsin. Similar in height and growth habit to Northcountry. Highly productive; ripens 7 days later than Northcountry. Similar in winterhardiness to Northsky, Northcountry, and Northblue.

Ira.-A rabbiteye blueberry with consistent cropping over a wide range of environments. Origin: North Carolina State Univ. from a cross made at Raleigh, N.C., by G.J. Galletta. Centurion x NC911. Introd. in 1997. Berry: larger than Tifblue; fruit color medium blue; flavor aromatic; picking scar, firmness, and soluble solids : acids ratio equal to Tifblue. Good shelf life. Plant: outstanding for consistent production over a wide range of environments. Flowers slightly later than Tifblue and ripens early-midseason. Flowers self-fertile but would probably benefit from cross-pollination. Desirable upright growth habit; good vigor, but somewhat less vigorous than Tifblue and Premier. Propagation rights assigned to Finch Nursery, Bailey, N.C.

Meader.-A winterhardy highbush blueberry. Origin: From the cross Earliblue x Bluecrop made by E.M. Meader. Sel. in 1955; introd. in 1971 by the New Hampshire Agr. Expt. Sta. Berry: large, borne in loose clusters, firm, easy to pick, scar small and dry. Berries do not crack; berries medium blue and sweeten soon after turning blue. Flavor mildly subacid. Plant: vigorous, erect, open growth, reliably productive if cross pollinated. Bushes may overbear if not pruned. Synchronous ripening. Good winterhardiness in New Hampshire.

Montgomery.-An early-ripening rabbiteye blueberry. Origin: From the cross NC763 x Premier made at Raleigh, N.C., by J.R. Ballington. Introd. in 1997. Berry: larger than Tifblue, smaller than Premier. Good picking scar, good color, and aromatic flavor. Fruit firmness average, like Premier. Resistant to cracking, stemming, and tearing, with self-life superior to Premier. Soluble solids : acid ratio equal to Tifblue. Plant: moderately vigorous, semi-upright, easy to train. Flowers partly self-fertile but needs cross pollination. A consistent producer. Propagation rights assigned to Finch Nursery, Bailey, N.C.

Pender.-A highbush blueberry for mechanical harvesting. Origin: North Carolina State Univ. from the cross Bluechip x B-1 (wild V. corymbosum) made by J.R. Ballington. Sel. in 1981; tested as NC2161; introd. in 1997. Berry: size smaller than Reveille and Croatan; color excellent, flavor good; very good picking scar; fruit firmness equal to Croatan. Resistant to cracking; good shelf life at 7 ${ }^{\circ} \mathrm{C}$. Plant: vigorous, semi-upright. Flowers synchronously with Croatan, ripens midseason; consistent in production. Can be mechanically harvested for the fresh market. Flowers are self-fertile. Propagation rights assigned to Finch Nursery, Bailey, N.C.

Putte.-A winterhardy half-high blueberry. Origin: at BalsgardThe Swedish Univ. of Agr. Sci. Introd. in 1986. A seedling from BV238 open pollinated. Berry: size small to medium; color black; medium scar; flavor mild and sweet; ripens midseason. Plant: bushy as Northblue; good winterhardiness and very productive.

Rubel.-A highbush variety of historical interest. Origin: Selected from the wild near Chatsworth, N.J., in 1912 by Rube Leek. Berry: rather small, good blue color; firm, slightly aromatic, tart; scar medium; good shipping and keeping quality; late ripening. Bush: original plant $2 \mathrm{~m}$ tall with 25 stems. Vigorous, erect, and productive. Good fall color.

Sampson.-A southern highbush blueberry with large fruit and a sturdy plant. Origin: from the cross Bluechip x NC1524 made by J.R.
Ballington at Raleigh, N.C. Introd. in 1998. Berry: very large; excellent picking scar, firmness and flavor; color average, better than Croatan. Plant: self-fruitful; flowers and ripens with or slightly before Croatan. Sturdy, vigorous plant with semi-upright growth habit. Propagation rights assigned to Finch Nursery, Bailey, N.C.

Santa Fe.-A low-chill southern highbush blueberry with high berry quality. Origin: Univ. of Florida in 1975 from open-pollinated seed from Avonblue. Sel. in 1977; tested as E-12; introd. in 1998. USPPAF. Berry: size medium to large; scar, firmness, and flavor good; color medium to dark blue. Plant: vigorous and upright. Chilling requirement similar to Sharpblue, $\approx 300 \mathrm{~h}$. Flowers and ripens early, about with Sharpblue. Yield medium to high. Requires crosspollination.

Summit.-A mid- to late-season southern highbush cultivar. Origin: From the cross G-144 x FL4-76 made by Arlen Draper in 1976. Tested as G-616. Introd. in 1997 by North Carolina State Univ., the Arkansas Agr. Expt. Sta.; and the USDA. Berry: size larger than Croatan and Bluecrop; color and flavor excellent; picking scar and firmness superior to Croatan; fruit cracking and stemming not significant. Exceeded Bluecrop and Climax in postharvest studies. Plant: semi-upright with medium vigor. Flowers are self-fruitful; Flowers synchronously with Croatan; ripens 2 weeks after Croatan; consistent production.

Yadkin.-A rabbiteye blueberry with excellent flavor and aroma. Origin: Developed at North Carolina State Univ. from the cross Premier x Centurion made by J.R. Ballington. Introd. in 1997. Berry: slightly larger than Tifblue; color medium blue; picking scar and firmness excellent; highly aromatic and excellent flavor. Shelf life superior to Premier; resistant to cracking, tearing, and stemming. Plant: medium vigor, semi-upright. Fruit concentrated on outer periphery of the bush; flowers slightly later than Tifblue and ripens with Tifblue. Flowers highly self-fertile but should be cross-pollinated where maximum earliness is important. Propagation rights assigned to Finch Nursery, Bailey, N.C.

\section{CARAMBOLA}

\section{Robert J. Knight, Jr. Univ. of Florida, Tropical Research and Education Center Homestead}

Arkin.-The most widely planted commercial cultivar in Florida. Origin: Florida, from Malaysian seed planted in 1973 by Morris Arkin of Coral Gables. Fruit: elongate-cylindrical with longitudinal indentations that make it star-shaped in cross section, with 5 broad ribs; averaging $12.2 \mathrm{~cm}$ long $\times 6.8 \mathrm{~cm}$ wide and $150 \mathrm{~g}$ in weight, with 9.4 seeds, or much less when grown in block plantings. Skin waxy, deep yellow; outstandingly firm, withstanding stresses of handling and shipping better than most other cultivars; fruit juicy, crisp, and of acceptable sweetness. Tree: upright, vigorous. Flowers long-styled.

B-10.- Important commercial cultivar in Malaysia and shipped to Japan. Origin: Malaysia, introd. to Florida by the Rare Fruit Council International of Miami in the early 1970s. Fruit: elongate-cylindrical, star-shaped in cross section with 5 ribs of sufficient thickness to tolerate shipping stresses well, averaging $10.2 \mathrm{~cm}$ long $\times 6.9 \mathrm{~cm}$ broad, weighing $115 \mathrm{~g}$ with 3.4 seeds on average; skin waxy, deep yellow; fruit of good firmness, juicy, crisp and pleasantly sweet. Tree: upright, vigorous. Flowers short-styled. Planted commercially on a small scale in Florida.

Demak.-An outstanding cultivar except for bitter aftertaste, and of potential use in breeding. Origin: Indonesia, coll. by plant explorers H.F. Winters and Higginsand, introd. by USDA in 1970. Fruit: large, cylindrical, and star-shaped in cross section, $10.2 \mathrm{~cm}$ long $\times 8.0 \mathrm{~cm}$ broad, weighing on average $185 \mathrm{~g}$, with 13.0 seeds when well crosspollinated; skin waxy, deep yellow; outstandingly firm with ribs similar in thickness to B-10. Flesh very crisp, juicy, and sweet but often with a bitter aftertaste. Tree: upright, spreading, vigorous. Flowers long-styled.

Fwang Tung.-Cultivar favored for planting in dooryard gardens. Origin: introd. to Florida from Thailand in 1973 by Robert J. Knight for the Rare Fruit Council International of Miami. Fruit: elongate- 
cylindrical, star-shaped in cross section with 5 ribs, averaging $11.5 \mathrm{~cm}$ long $\times 8.5 \mathrm{~cm}$ broad and weighing $150 \mathrm{~g}$ with 6 seeds; skin waxy, light yellow approaching white in color; not outstandingly firm, with ribs too thin and wavy to ship well. Flesh crisp, juicy, and pleasantly sweet. Tree: upright-spreading, with dense, healthy growth. Flowers shortstyled.

Hew-1.-Firm, yellow cultivar. Origin: Malaysia, introd. from Singapore to Florida by Dr. Robert A. McNaughton of the Rare Fruit Council International in the early 1970s. Fruit: elongate-cylindrical, star-shaped in cross section, $12.5 \mathrm{~cm}$ long $\times 7.0 \mathrm{~cm}$ broad on average, weighing $140 \mathrm{~g}$ with an average of 5.4 seeds. Skin waxy, deep yellow but sometimes disfigured by medium-sized white dots; firmness excellent; flesh crisp, juicy, and pleasantly sweet-flavored. Tree: spreading, vigorous. Flowers short-styled.

\section{CHERRY - SWEET \\ Gregory A. Lang Washington State Univ., IAREC Prosser, Wash.}

Redlac.-Productive dark red cherry ripening with Van. Origin: in LeGrande, Ore., by Don Calder. Introd. in 1998. USPP 8721; assigned to Calder Riverside Nursery. Apparent budsport of Rainier found in 1985. Fruit: large, with long stems; dark red skin and light red flesh, very good sweetness; midseason ripening, similar to or slightly after Van. Tree: may be partially self-fertile; vigorous, yet spreading; very productive; good cold hardiness.

Sandra Rose.-Self-fertile cherry resembling Van. Origin: in Summerland, British Columbia, by K.O. Lapins, Pacific Agri-Food Research Centre. Introd. in 1996. Canadian Plant Breeder's Rights (\#0320) granted in 1998 and USPPAF; assigned to Okanogan Plant Improvement Company. 2C-61-18 x Sunburst; tested as 13S-10-40. Fruit: large, resembling Van with short, thick stems and slightly "blocky," rounded shape; bright, shiny dark red skin; dark red flesh, moderately firm, sweet, with good flavor; good tolerance to rainsplitting; ripens midseason, $\approx 3$ days after Van. Tree: self-fertile, begins bloom 1 day after Van; spreading growth habit; very productive.

Santina.-Self-fertile black-skinned cherry. Origin: in Summerland, British Columbia, by K.O. Lapins and H. Schmidt, Pacific Agri-Food Research Centre. Introd. in 1996. Canadian Plant Breeder's Rights and USPPAF; assigned to Okanogan Plant Improvement Company. Stella x Summit; cross made in 1973, selected in 1981; tested as 13S-5-22. Fruit: moderately large, oval with a medium-long stem; black skin; firm flesh, moderately sweet; moderate tolerance to rain-splitting; early-ripening, $\approx 8$ days before Van. Tree: self-fertile, begins bloom 1 day after Van; moderate productivity.

Simcoe.-Early-ripening Bing-type cherry. Origin: in Prosser, Wash., by Thomas Toyama, Washington State Univ.. Introd. in 1995. USPPAF; assigned to Northwest Nursery Improvement Institute. Stella X (Hollander or Starking Hardy Giant); cross made in 1971, selected in 1981; tested as PC 7147-1. Fruit: large, resembling Bing (heart-shaped); dark red skin; firm, moderately sweet with a sweet/tart flavor; good tolerance to rain-splitting; early-ripening, $\approx 8$ days before Van. Tree: self-sterile, begins bloom 1 day after Van; upright growth habit; good productivity.

Skeena.-Very firm, late-ripening cherry. Origin: in Summerland, British Columbia, by David Lane, Pacific Agri-Food Research Centre. Introd. in 1997. Canadian Plant Breeder's Rights (\#0319) granted in 1998 and USPPAF; assigned to Okanogan Plant Improvement Co. 2N60-07 x 2N-38-32; tested as 13S-42-48. Fruit: large, round, with thick stems; very attractive dark red to black skin; very firm, moderately sweet; good tolerance to rain-splitting; late-ripening, $\approx 12-16$ days after Van. Tree: self-fertile, blooms with Van; spreading growth habit; precocious and very productive.

\section{Sumleta.-See Sumleta Sonata.}

Sumleta Sonata (Sumleta).-Self-fertile, black-skinned cherry. Origin: Summerland, British Columbia, by David Lane, Pacific AgriFood Research Centre. Introd. in 1996. Canadian Plant Breeder's Rights (\#0317) granted in 1997 and USPPAF; assigned to Okanogan Plant Improvement Company. Lapins X 2N-39-5; tested as 13N-6-59.
Registered in Europe in 1995 as Sumleta. Fruit: very large, with long and thick stems; attractive black, lustrous skin; very firm, moderately sweet; susceptible to rain-splitting; mid-to-late ripening, $\approx 7$ days after Van. Tree: self-fertile, begins bloom 1 day after Van; good productivity.

\section{Sumnue.-See Sumnue Cristalina.}

Sumnue Cristalina (Sumnue).-_Early-ripening Bing type. Origin: in Summerland, British Columbia, by K.O. Lapins and H. Schmidt, Pacific Agri-Food Research Centre. Introd. in 1996. Canadian Plant Breeder's Rights (\#0318) granted in 1997 and USPPAF; assigned to Okanogan Plant Improvement Co. Star x Van; cross made in 1962, selected in 1968; tested as 2C-61-22. Registered in Europe in 1995 as Sumnue. Fruit: moderately large, resembling Bing (heartshaped); flesh and skin are dark red; firm, moderately sweet; good tolerance to rain-splitting; can be picked stemless; early-to-midseason ripening, $\approx 5$ days before Van. Tree: self-sterile, begins bloom 1 day after Van; spreading branch habit; very productive.

Sumpaca.-See Sumpaca Celeste.

Sumpaca Celeste (Sumpaca).- - High-quality cherry similar to Van but earlier. Origin: in Summerland, British Columbia, by K.O. Lapins and H. Schmidt, Pacific Agri-Food Research Centre. Introd. in 1993. Canadian Plant Breeder's Rights (\#0316) granted in 1997 and USPPAF; assigned to Okanogan Plant Improvement Co. Van $\mathrm{x}$ Newstar; cross made in 1974, selected in 1981; tested as 13S-24-28. Registered in Europe in 1995 as Sumpaca. Fruit: moderately large, resembling Van with short stems and slightly "blocky" shape; flesh is dark, firm, sweet; very good flavor; good tolerance to rain-splitting, somewhat prone to pitting; early ripening, $\approx 5-7$ days before Van. Tree: self-fertile, begins bloom 4 days after Van; semi-compact growth habit; moderate productivity.

Sumste.-See Sumste Samba.

Sumste Samba (Sumste).-Midseason, dark red cherry that is self-fertile. Origin: in Summerland, British Columbia, by David Lane, Pacific Agri-Food Research Centre. Introd. in 1996. Canadian Plant Breeder's Rights and USPPAF; assigned to Okanogan Plant Improvement Company. 2S-84-10 x Stella; tested as 13S-36-18. Registered in Europe in 1995 as Sumste. Fruit: large, bright and attractive dark red skin; firm, moderately sweet, with good flavor; good tolerance to rain-splitting; ripens midseason, $\approx 2$ days after Van. Tree: self-fertile, begins bloom 3 days before Van; spurry growth habit; not precocious.

Sweetheart.-Self-fertile, red-skinned cherry. Origin: in Summerland, British Columbia, by David Lane, Pacific Agri-Food Research Centre. Introd. in 1994. Canadian Plant Breeder's Rights and USPPAF; assigned to Okanogan Plant Improvement Company. Van $\mathrm{X}$ Newstar; cross made in 1975; tested as 13S-22-8. Fruit: moderately large, round; red skin and flesh; very firm, moderately sweet with fair to good flavor; moderate tolerance to rain-splitting; may be susceptible to sunscald under very hot conditions; late-ripening, $\approx 19-22$ days after Van. Tree: self-fertile, begins bloom 1 day before Van; spreading growth habit; precocious and very productive.

Symphony.-Self-fertile, late-ripening cherry. Origin: in Summerland, British Columbia, by David Lane, Pacific Agri-Food Research Centre. Introd. in 1997. Canadian Plant Breeder's Rights (\#0321) granted in 1998 and USPPAF; assigned to Okanogan Plant Improvement Company. Lapins X Bing; tested as 13S-25-25. Fruit: moderately large; firm, moderately sweet with a pleasant flavor; good tolerance to rain-splitting; late-ripening, $\approx 20$ days after Van. Tree: self-fertile, begins bloom 1 day after Van.

Tehranivee.-Self-fertile, upright cherry ripening in midseason. Origin: in Vineland Station, Ontario, by Ghassem Tehrani, Horticultural Research Institute of Ontario. Introd. in 1996. Canadian Plant Breeder's Rights (\#0327) granted in 1997. Van X Stella; cross made in 1969, selected in 1982; tested as V690620. Fruit: large, flat-round shaped and symmetrical, with a long stem; dark red skin and flesh; moderately firm, juicy, very sweet; good tolerance to rain-splitting; mid-to-late ripening, $\approx 5$ days after Van. Tree: self-fertile, blooms late; upright growth habit; precocious and very productive. Prepared for release under a different name by G. Tehrani and renamed by his colleagues upon his untimely death.

Tieton.-Very large, glossy, early-ripening cherry. Origin: in 
Prosser, Wash., by Thomas Toyama, Washington State Univ. Introd. in 1998. USPPAF; assigned to Northwest Nursery Improvement Institute. Stella X Early Burlat; cross made in 1971, selected in 1977; tested as PC 7144-6. Fruit: very large, somewhat blocky heart shape, thick stems; very attractive, glossy dark red skin; firm, moderately sweet with a mild flavor; average susceptibility to rain-splitting; earlyripening, 7-9 days before Van. Tree: self-sterile, blooms with Van; upright growth habit; light to moderate productivity.

Vandalay.-Very sweet, midseason cherry. Origin: in Vineland Station, Ontario, by Ghassem Tehrani, Horticultural Research Institute of Ontario. Introd. in 1996. Canadian Plant Breeder's Rights (\#0326) granted in 1997. Van X Stella; cross made in 1969, selected in 1980; tested as V690618. Fruit: large, kidney-shaped and symmetrical, with a medium stem; wine-red skin and dark-red flesh; firm, moderately juicy, very sweet; good tolerance to rain-splitting; earlyto-mid ripening season, $\approx 5$ days before Van. Tree: self-fertile, blooms early; spreading growth habit; precocious and very productive.

\section{CURRANT}

\section{Kim E. Hummer \\ USDA-ARS National Clonal Germplasm Repository Corvallis, Ore.}

Beloruskaya Sladkaya.-Early, disease-resistant black currant. Origin: developed in Belarus by A. Voluzniovas of the Belarus Fruit Farming Science Research Institute. Hybrid of European and Siberian R. nigrum. Released from the state in 1967, tested in Lithuania in 1984. Fruit: medium firm, medium large, weighing $\approx 1.1 \mathrm{~g}$; sweet flavor; uniform ripening; very good separation from stalk; vitamin $C: 135$ to 156 mg per 100 g. Plant: vigorous, broad upright, cold hardy; trusses medium long; early flowering; reversion, black currant gall mite, leaf spot and white pine blister rust resistant; one of the main cultivars of the former Soviet states; available in the United States.

Brodtorp.-Midseason, cold hardy, black currant. Origin: Discovered in Brodtorp, Finland. Selection of local $R$. nigrum. Introd. in 1984. Fruit: firm, medium size; 0.9 to $1.0 \mathrm{~g}$; sweet; uniformly ripening; very good separation from the truss. Plant: medium vigor; spreading growth habit; cold hardy; resistant to spring frost; leaf spot and white pine blister rust susceptible; reversion and black currant gall mite resistant.

Golubka.-Standard Russian black currant. Origin: developed by M. Lisavenko, N. Kravceva, N. Pavlova, and I. Kucharskij in Russia. $R$. nigrum $\times$ R. dikuscha. Introd. in 1938. Fruit: small; 0.6 to $0.7 \mathrm{~g}$; medium firmness; equally sour and sweet; vitamin C: $178.5 \mathrm{mg}$ per $100 \mathrm{~g}$; uniform ripening; medium length truss; very good separation from truss; Plant: medium vigor; medium spreading habit; cold hardy; spring frost resistant; susceptible to leaf spot and white pine blister rust; somewhat susceptible to reversion and black currant gall mites.

Jonkheer van Tets.-Early- to mid-ripening red currant. Origin: developed by J. Maarse, in Schellinkhout, The Netherlands. $R$. spicatum and $R$. sativum hybrid; cross of Fay's Prolific and a Scotch selection. Crossed in 1931, and introd. in 1941. Fruit: medium size, $0.86 \mathrm{~g}$, bright red, sweet. Plant: medium vigor; medium length trusses, 9.2 $\mathrm{cm}$; early flowering; leaf spot susceptible; low run-off; American powdery mildew and white pine blister rust resistant.

Junifer.-Early-ripening red currant. Origin: Developed at Centre de Recherches Agronomique d'Angers, Angers, France. Seedling selection of Fay's Prolific. Introd. in 1967. Plant Breeder's Rights obtained in 1978. Fruit: large on young shoots; early ripening. Plant: vigorous; flowers 5 days earlier than Jonkheer van Tets; low chilling; good productivity; ease of harvest good; suited for commercial production. Early production comparable to Jonkheer van Tets.

Minaj Smyriov.-Mid-early-ripening, rust-resistant black currant. Origin: Developed in Belarus by A. Voluzniovas of the Belarus Fruit Farming Science Research Institute. Complex hybrid of European $R$. nigrum and Siberian subspecies with Golubka. Accepted for state research in 1967; district tested in Lithuania in 1980. Protected under Plant Breeder's Rights. Fruit: large, round, weighing $\approx 1 \mathrm{~g}$; dull black; shipping qualities good, thin-skinned, sour-sweet average taste;
2 sugar : 1 acid ratio; vitamin C: 82 to $132 \mathrm{mg}$ per $100 \mathrm{~g}$; used fresh or for processing; truss long, on young growth, axis thin and bent; pedicle long, brownish green, thin; berries ripen uniformly and are persistent; fruit separates easily from pedicle. Plant: cold hardy; blooms one day earlier than Golubka; yields well in second year; self-pollinating; higher yield than Golubka; vigorous and somewhat spreading; thick stems; susceptible to mildew and black currant gall mite in Europe; resistant to white pine blister rust under natural infection in Pennsylvania and Oregon.

Ojebyn.-Standard Swedish black currant. Origin: Discovered in the wild in Ojebyn, Sweden. Selection of local R. nigrum. Introd. in 1953. Fruit: small to medium size, $1.0 \mathrm{~g}$; medium firmness; flavor equally acid and sweet; vitamin C: $120.6 \mathrm{mg}$ per $100 \mathrm{~g}$; shipping quality good. Plant: cold hardy; compact, spreading growth habit; medium yield; leaf spot and white pine blister rust susceptible.

Ometa.-Mildew-resistant black currant for commercial processing, fresh market, and home gardens. Origin: Developed by Dr. Rudolf Bauer in Germany. Westra $\mathrm{X}$ mildew resistant $R$. nigrum; selected in the 1970s; protected by German Plant Breeder's Rights. Fruit: medium to large berries on long trusses with a long stalk; high quality (one of the most aromatic of all cultivars), high juice color, easy to harvest. Plant: yield high, vigorous growth, annual regeneration in the middle and the upper part of the bush, few suckers; ripens midseason, from mid- to late July; resistant to American powdery mildew, white pine blister rust, and to gall mite; high value for commercial production for processing purposes and for fresh market; good for home gardening because of fruit quality and plant disease resistance.

Pilot Alexandr Mamkin.-Mid-early, cold-hardy, gall miteresistant black currant. Origin: developed in Belarus by A. Voluzniovas, N. Zazulina, and A. Radiukas of the Belarus Fruit Farming Science Research Institute. R. nigrum $\times$ R. pauciflorum. Introd. in 1967. Fruit: small, $\approx 0.8 \mathrm{~g}$; color is similar to Magnus; ripening not uniform; acid and sugar levels are high; vitamin C: 104 to $109 \mathrm{mg}$ per $100 \mathrm{~g}$. Plant: vigorous, spreading; cold hardy; spring frost resistant; productivity good; black currant gall mite resistant; white pine blister rust susceptible; may be suitable for dairy flavorings and bakery products.

Rolan.-Midseason red currant for fresh commercial production and home gardens. Origin: developed by L.M. Wassenaar at the Institute for Horticultural Plant Breeding in Wageningen, The Netherlands. Jonkheer van Tets x Rosetta. Introd. in 1961. Plant Breeder's Rights obtained in 1981. Fruit: large, $0.88 \mathrm{~g}$, on long trusses, $14 \mathrm{~cm}$; medium red, good fruit quality, easy to harvest. Plant: yield high to very high; vigorous, erect habit, good basal suckers, mid- to lateflowering, later than Jonkheer van Tets; susceptible to American powdery mildew in the United States but reported resistant in Europe; resistant to leaf spot, and cracking; medium susceptibility to run-off; white pine blister rust resistant.

Rondom.-Late-ripening red currant. Origin: developed by J. Rietsema in Breda, The Netherlands. Selection of $R$. multiflorum. Introd. in 1934. Plant Breeder's Rights, 1949. Fruit: medium size, 0.7 g, bright red. Plant: vigorous; upright; productivity very good; midseason blooming; late ripening; medium-long trusses, $9.1 \mathrm{~cm}$; easily harvested; slightly leaf spot susceptible; American powdery mildew, run-off, and white pine blister rust resistant.

Rosetta.-Mid- to late-season red currant. Origin: developed by L.M. Wassenaar. Institute for Horticultural Plant Breeding, Wageningen, The Netherlands. Jonkheer van Tets $x$ Heinemanns Rote Spatlese. Introd. in 1962. Protected by Dutch Plant Breeder's Rights in 1974. Fruit: medium size $0.78 \mathrm{~g}$, bright red. Plant: fairly vigorous, mostly upright; late flowering, midseason ripening; high yielding; medium-long trusses, $9.3 \mathrm{~cm}$; low run-off; American powdery mildew and white pine blister rust susceptible.

Rotet.-High-yielding, high-quality, midseason red currant for all-around use. Origin: developed by L.M. Wassenaar at Institute for Horticultural Plant Breeding, The Netherlands. Jonkheer van Tets $\mathrm{X}$ Heinemanns Rote Spatlese. Introd. in 1963. Protected by Dutch Plant Breeder's Rights in 1974. Fruit: large berries on long trusses; medium to dark red; good flavor quality; easy to harvest; keeps well on the bush. Plant: yield high to very high; vigorous; suckers from base; ripens late midseason, usually in mid-July; resistant to American powdery mil- 
dew, leaf spot, run-off, and fruit cracking; valuable for commercial processing production because of dark juice color and high acidity, and good for home gardens because of fruit quality, high yield, and disease resistance.

Rovada.--Very high-yielding, late, red currant for commercial production and home gardens. Origin: developed by L.M. Wassenaar at Institute for Horticultural Plant Breeding, Wageningen, The Netherlands. Fay's Prolific x Heinemann's Rote Spatlese. Introd. in 1980. Protected by Dutch Plant Breeder's Rights. Fruit: large berries, $1.0 \mathrm{~g}$, on long trusses, $22.4 \mathrm{~cm}$; dark red; good fruit quality; easy to harvest. Plant: yield very high; vigorous, erect; suckers from base; ripens late, at the mid- to the end of July; resistant to American powdery mildew, white pine blister rust, leaf spot, and cracking; susceptible to run-off; main variety for commercial production because of excellent fruit quality and yield; also suited to home gardens.

Tenah.-Fresh-market black currant for commercial production. Origin: developed in Tilburg, The Netherlands. \{[(Goliath $\times R$. nigrum) $\times$ R. nigrum] $\times$ Brodtorp $\}$ Introd. in 1959. Propagation rights with G. Hanet, Veules-les-Roses, France, from 1973. Fruit: large berries on long trusses, even size and ripening, good interior and exterior fruit quality, easy to harvest by hand or by machine. High in vitamin C. Plant: high and consistent yielding, vigorous, spreading; trellising recommended; ripens in early midseason at the beginning of July; fruit trusses can break; not recommended for machine harvest. Susceptible to American powdery mildew and white pine blister rust; released for fresh-market commercial production because of the exterior fruit quality and easy hand harvesting.

Tsema.-Fresh-market black currant for commercial production. Origin: developed in Tilburg, The Netherlands. $\{[$ Goliath $\times R$. nigrum $) \times R$. nigrum] $\times$ Brodtorp $\}$ Introd. in 1959. Propagation rights with G. Hanet, Veules-les-Roses, France from 1973. Fruit: large berries on long trusses, even size and ripening, good interior and exterior fruit quality, easy to harvest by hand or by machine. High in vitamin C. Plant: high and consistent yielding, vigorous, spreading; trellising recommended; ripens in early midseason at the beginning of July; susceptible to American powdery mildew and white pine blister rust; released for fresh-market commercial production because of exterior fruit quality and easy hand harvesting.

Titania.-Midseason, rust-resistant black currant for commercial production for processing. Origin: developed in Sweden by P. Tamas. [Altajskaja Desertnaja x (Consort x Kajaanin Musta)]. Cross made in early 1970s. Swedish Plant Breeder's Rights issued to P. Tamas 18 Dec. 1980. Cultivar description published in 1984. Fruit: large berries on medium-long trusses, uniform ripening, high acidity, good flavor, keeps well on the bush. Plant: very high yield; vigorous, regular pruning of 4- to 5-year-old shoots needed; high self-fertility; ripens midseason, from the beginning to mid-July; resistant to American powdery mildew and white pine blister rust; susceptible to aphids and red spider mite; good for commercial production for processing because of high yields and good processing quality; good for home gardens because of disease resistance.

\section{GOOSEBERRY}

\section{Kim E. Hummer \\ USDA-ARS National Clonal Germplasm Repository Corvallis, Ore.}

Golda.-Yellow, midseason gooseberry. Origin: developed by L.M. Wassenaar Institute for Horticultural Plant Breeding, Wageningen, The Netherlands. Whitesmith x May Duke. Introd. in 1972. Dutch Plant Breeder's Rights beginning 1985. Fruit: yellow, large. Ripens late midseason. Plant: high yielding; somewhat susceptible to American powdery mildew.

May Duke.-Old red-fruited variety for commercial production. Origin: discovered in Pyne, Topsham, England. Selection of R. uvacrispa. Introd. around 1890. Fruit: large, round to broadly elliptical berries; good flavor; easy to harvest; cracks in rain. Plant: yield medium; vigorous, erect; ripens early, at the beginning of July. Susceptible to American powdery mildew and leaf spot. Grown in England and Europe for fresh-market commercial production.

Mucurines.-Yellow-green gooseberry. Origin: unknown Euro- pean selection of R. uva-crispa. Introd. in the late 1890 s or early $1900 \mathrm{~s}$. Fruit: green, large, broad elliptical berries, good flavor, easy to harvest; does not crack; keeps well on the bush. Plant: high yield; vigorous, very erect, suckers from base; ripens midseason. Resistant to American powdery mildew and leaf spot. Grown for commercial production and home gardens because of resistance, yield, and fruit size.

Rokula.-Early-ripening gooseberry for home garden production. Origin: developed in Germany by Dr. Rudolf Bauer of the Max Plank Institute. Mauk's Early Red x mildew resistant $R$. uva-crispa. Introd. in 1960s. Protected by German Plant Breeder's Rights. Fruit: red, round, large, $9 \mathrm{~g}$, excellent quality and flavor; cracks in rain. Plant: yield medium; medium vigor, slightly drooping habit, trellising helpful; ripens very early, at the end of June. Resistant to American powdery mildew of fruit and to other leaf diseases. Valuable to home gardens for earliness, resistance and excellent flavored fruit.

Rolonda.-High-yielding, mildew-resistant home garden gooseberry for organic production. Origin: developed in Germany by Dr. Rudolf Bauer of the Max Planck Institute. Complex cross of gooseberry cultivars and wild species. Released in 1985. Protected by German Plant Breeder's Rights. Fruit: dark red or nearly black when fully ripe; medium size, ovate to pyriform; flavor of medium quality, very sweet when fully ripe, keeps well on the bush. Plant: medium vigor, semi-erect habit; yield high; ripens midseason, from early to mid-July. Resistant to American powdery mildew, leaf spot, cracking.

Rosco.-Midseason red gooseberry. Origin: developed by L.M. Wassenaar, at the Institute for Horticultural Plant Breeding, Wageningen, The Netherlands. Gladde Gele x Whinham's Industry. Tested as IVT 72002. Introd. in 1972. Dutch Plant Breeder's Rights beginning 1985. Fruit: large, round, reddish blush over green ground color. Plant: high yielding; somewhat susceptible to American powdery mildew.

\section{GRAPE}

John R. Clark

Univ. of Arkansas, Fayetteville

3-14-71.-A large-fruited, dark-red to black-skinned, seedless table grape that ripens 2 weeks after Thompson Seedless. Origin: in Davis, Calif., by H.P. Olmo. USPP 8297; 13 July 1993; assigned to Marko Zaninovich, Delano, Calif. Hunisa OP x Q25-6; cross made in 1982; selected in 1985. Fruit: large, with mean weight of the 10 largest berries per cluster of $35.5 \mathrm{~g}$; berry size increased substantially by girdling; ellipsoidal and flattened at point of attachment; dark red to black depending on maturity; seedless but often with two collapsed and soft seed rudiments; thin skin; meaty and firm flesh; flavor neutral; ripens late September to mid-October at McFarland, Calif., 2 weeks after Thompson Seedless; excellent shipping, handling and storage capability. Cluster: conical; well-filled; average weight 446 g; mean berries/cluster 175. Vine: vigorous; upright in growth habit; highly fruitful even on basal buds and can be pruned to short spurs.

552.-A dark-maroon to light-red, seedless table grape that ripens 2 weeks after Flame Seedless. Origin: in Mendoza, Argentina, and Delano, Calif., by Angel A. Gargiulo. USPP 9916; 10 June 1997; assigned to Luis M. Caratan, Delano, Calif. Patagonia x Galaxy; cross made in 1987 in Argentina and seedlings planted near Delano, Calif. Fruit: large, $2.5 \mathrm{~cm}$ in length; obovate; dark-maroon to lighter red toward the base of the berry; sweet; firm and crisp; seedless with occasionally one to two small, undeveloped rudimentary seed traces; ripens 1 Aug. at Delano. Calif., $\approx 2$ weeks after Flame Seedless. Cluster: medium to large, 21 to $26 \mathrm{~cm}$ length; loose; 86 to 106 berries/ cluster. Vine: vigorous; moderately productive; cane pruned.

Argaman.-Highly colored, productive wine cultivar. Origin: in Bet-Dagan, Israel, by P. Spiegel-Roy, S. Cohen, I. Baron, R. Assaf, S. Ben-A'haron, and M.J. Striem. Plant Patent 950 in Israel, 1992. Souzao x Carignan; cross made in 1972; tested as selection 401. Fruit: medium, $1.5 \mathrm{~g}$; round; blue to black; seeded; ripens mid-August to early September, 2 to 3 weeks before Carignan; wines made from Argaman were judged more favorably than Carignan and are deeply colored with satisfactory to average acidity and tannins, of good body 
and balance. Cluster: medium (280-300 g); cylindrical; moderately compact. Vine: vigorous and productive on Richter 110 or Ruggeri 140R rootstocks; productivity comparable to Carignan; less sensitive to powdery mildew (Uncinula necator) than Carignan.

Brighton 650.-An early-ripening, yellow-green, seedless table grape for fresh market or raisins. Origin: near Thermal, Calif., by Howard B. Keck, Jr. USPP 8499; 14 Dec. 1993; assigned to Brighton Farming Co., Thermal, Calif. A sport of Superior Seedless; discovered in 1986. Fruit: variable oval; medium to large; 125 berries/cluster; yellow-green; skin thick, tough and adheres to the pulp; meaty; texture soft, tender, firm and crisp; flavor sweet with slight muskiness; seedless; good to excellent storage and shipping quality; ripens 25 May to 5 June near Thermal, Calif., $\approx 11$ days earlier than Superior Seedless. Cluster: large, 600 to $1100 \mathrm{~g}$; two to five clusters/shoot; irregular shape; double-shouldered; loose to medium berry density. Vine: vigorous; upright; very productive; buds from the third bud from the base of the cane to more distal are usually fruitful.

Emperatriz.-A seedless table grape resembling the seeded cultivar Emperor. Origin: near Rama, Caida, Argentina, by Angelino A. Gargiulo. USPP 5833; 16 Dec. 1986; assigned to Milan M. Caratan, and Luis M. Caratan, Delano, Calif. Emperor X Thompson Seedless. Fruit: ovoid; size medium and varies unless treated with gibberellic acid; pink to reddish; 300 berries/cluster; seedless with two soft seeds/ berry; flavor has a touch of plum, not very sweet, acid; excellent shipping and storage quality; ripens 7 days earlier than Emperor; use for table, raisin, and wine. Cluster: loose; ripens unevenly unless treated with gibberellic acid. Vine: vigorous; high productivity.

Flamed Globe.-Seeded table grape ripening 3 to 4 weeks earlier than Emperor. Origin: in Delano, Calif., by George A. Lucas, Sr. USPP 6458; 13 Dec. 1988. Unknown parentage. Fruit: large; obovoid; seeded; reddish-brown; excellent eating and shipping quality; ripens $\approx 1$ Sept., 3 to 4 weeks earlier than Emperor. Cluster: oblong; medium; ripens evenly. Vine: vigorous; high productivity.

Polyanna.-A large-fruited, self-fruitful purple muscadine cultivar for fresh market. Origin: in Leesburg, Fla., by P.C. Andersen, J.A. Mortensen, and J.W. Harris, Univ. of Fla. Fry X Southland; cross made in 1979; selected in 1981; tested as FL CD8-81; introd. in 1998. Not patented. Fruit: round; purple; large ( 9 to $10 \mathrm{~g}$ ); soluble solids $16.7 \%$ to $18.7 \%$; flavor rated good to excellent, superior to Jumbo in evaluations; texture good to excellent, tender and melting; skin mediumthin and edible; picking scars $90 \%$ dry; seeds average 3.4/berry; ripens later than many cultivars, beginning at the end of August and ending at the end of September. Cluster: three to four berries/cluster. Vine: perfect flowered and recommended as a pollinizer for pistillate cultivars; intermediate vigor; productive; Pierce's disease (Xylella fastidiosa) has not been observed on Polyanna; fungicide sprays have not been required to control fungal pathogens on fruit; no economic injury from insects has been observed.

Ralli Seedless.-A low-acid, red, seedless table grape. Origin: in Victoria, Australia, by Giuseppe Ralli, Iolanda Ralli, John Ralli, and Joseph Ralli. USPP 9865; 22 Apr. 1997; assigned to G \& I Ralli and Sons, Victoria, Australia. Spontaneous mutation of Menindee Seedless (also known as Sugraone and Superior Seedless). Fruit: elliptic; medium to large; cardinal red; seedless with two to three rudimentary, soft seed traces/berry which are not noticeable when eaten; low acid $(0.53 \mathrm{~g} / 100 \mathrm{~mL}$ acidity at $16 \%$ soluble solids $)$; flesh firm; texture crisp; skin tough; stores very well, up to 8 weeks and ships extremely well, comparable to Thompson Seedless; ripens $\approx 4$ days earlier than Menindee Seedless and 12 to 15 days earlier than Thompson Seedless. Cluster: large, 500 to $750 \mathrm{~g}$; conical; loose. Vine: vigorous.

Sugrathirteen.-A large-fruited, early-ripening, seedless table grape. Origin: in Wasco, Calif., by David W. Cain. USPP 10434; 9 June 1998; assigned to Sun World, Bakersfield, Calif. Seedling 17-138 (Italia $\times$ Sugraone) $\times$ Fantasy Seedless; ovule cultured from the cross made in 1990; selected in 1992. Fruit: large, $4.7 \mathrm{~g}$, and if treated with gibberellic acid, $9.3 \mathrm{~g}$; long elliptic; black; skin average thickness; medium texture; neutral flavor; $16.7 \%$ soluble solids; good shipping quality; ripens early, $\approx 30$ days before Thompson Seedless. Cluster: large, average $671 \mathrm{~g}$; conical; medium berry density; 147 berries/ cluster. Vine: vigorous; medium productivity; typically cane pruned leaving five to seven 16-bud canes/vine.

\section{MANGO}

Robert J. Knight, Jr. Univ. of Florida, Tropical Research and Education Center Homestead

Appus.-See Alphonso.

Alphonso (Appus, Badami, Gundu, Haphus, Kagdi, Khader, Khader Pasand). - High-quality mango bringing premium prices on Indian and international markets Origin: India. Tree: moderately large, with broadly rounded, dense canopy. Fruit: yellow, ovateoblique, averaging $60 \mathrm{~mm}$ long by $50 \mathrm{~mm}$ broad, weighing 225-325 $\mathrm{g}$, averaging $226 \mathrm{~g}$; skin thin, flesh firm to soft, low in fiber, yellow, sweet with characteristic aroma and pleasant taste preferred by many who know this cultivar. Seed monoembryonic in a large, woody stone, quality excellent. Late midseason; irregular bearer, medium to heavy in India but light and irregular in Florida.

Aman Dusehri.-See Dashehari.

Amélie.-Early ripening with fruit that resembles that of Julie. Origin: West Indies, grown in W. Africa. Tree: tall, with rounded, dense canopy. Fruit: green to orange-yellow with the advance of the season, rounded, $100-150 \mathrm{~mm}$ long by $\approx 100 \mathrm{~mm}$ broad by $\approx 78 \mathrm{~mm}$ thick, weighing 300-600 g, averaging $360 \mathrm{~g}$; skin thick and separated with difficulty, flesh soft, juicy, melting, without fiber, deep orange, sweetly perfumed, free from turpentine. Seed monoembryonic in a medium-sized elongate, narrow stone that adheres to the flesh, with a few short, pliable fibers that are not objectionable; quality excellent.

Arumanis (Harumanis).-Widely planted mango in humid parts of the world where many cultivars fail to fruit. Origin: Indonesia. Tree: vigorous, tall with slightly open canopy. Fruit: greenish-yellow with large, light-yellow dots, elongate oblong with rounded base, 110$140 \mathrm{~mm}$ long by $66-75 \mathrm{~mm}$ broad by $47.5-65 \mathrm{~mm}$ thick, weighing 200-350 g; skin thin, tough and easily separated, flesh firm and juicy with little fiber, lemon-yellow, sweet, slightly insipid with a strong aroma, of poor to fair quality; seed polyembryonic in thick, woody stone. Midseason, bears regularly. Easy to propagate by graftage, scionwood survives well.

Badami.-See Alphonso.

Bangalora.-See Totapuri.

Bhojpuri.-See Bombay Green.

Bombai.-See Bombay Green.

Bombay Yellow.-See Bombay Green.

Bombay Green (Bhojpuri, Bombai, Bombay Yellow, Hiralal Bombai, Kali Bombai, Laile Alipur, Malda, Peter, Sarauli, SheeriDhan).-Early high-quality mango long been grown in Jamaica. Origin: India. Tree: tall and erect. Fruit: apple green with yellowochre blush at base and on some exposed parts, dots abundant with brown specks in the middle; ovate with beak almost missing, mediumsized, with tough, thick, nonadhering smooth skin, flesh cadmiumorange, firm and juicy with scant fiber just under the skin, very sweet with pleasant aroma, of very good quality; seed monoembryonic in a full, thick, medium-sized stone. Season early. A medium bearer. Introductions from Jamaica to Florida have not done well, and have fruited poorly. Bombay Yellow is said to be practically identical to Bombay Green but for a slight external color difference.

Bowen.-See Kensington.

Chausa (Kharaji, Samar Bahisht Chausa).-Excellent quality late mango. Origin: India. Tree: tall and spreading. Fruit: canary yellow to raw sienna when fully ripe, with numerous obscure mediumsized dots with minute specks inside them, oblong with prominent beak, obtuse to rounded, medium-sized, skin thin and somewhat adhering, pulp raw sienna, soft and juicy with scanty fine, long fibers near the skin, very sweet and luscious, delightful aroma, of excellent quality; seed monoembryonic in a thick, medium-sized oblong stone with fine, short fibers all over its surface and a tuft of long fibers on the ventral edge. Season late; a light bearer.

Collector.-See Totapuri.

Darbhanga.-See Langra.

Dashehari (Aman Dusehri, Dasheri).-Aromatic fruit with nonadhering flesh. Origin: India. Tree: medium height and of moderate vigor, upright and spreading, with a rounded, medium-dense canopy. Fruit: primrose to canary-yellow with abundant light yellow 
dots, oblong to oblong-oblique with base rounded to obliquely rounded, medium-sized, $101 \mathrm{~mm}$ long by $51 \mathrm{~mm}$ broad by $57 \mathrm{~mm}$ thick, averaging $169 \mathrm{~g}$; skin smooth, medium-thick, tough and nonadhering, flesh yellow, firm, with almost no fiber, scanty juice and a delightful aroma, very sweet taste, of excellent quality; seed monoembryonic in a thick, medium-sized stone. Midseason, heavy bearing; fruit keeps well.

Dasheri.-See Dashehari.

David Ford.-See Langra.

Ewais.-A popular commercial cultivar in Egypt. Origin: Egypt. Tree: vigorous. Fruit: yellow with no blush, with small light brown dots that are slightly corky, oblong-cylindric with the convex side rounded, but a flattened apex, a shallow stem-end cavity, $117 \mathrm{~mm}$ long by $72 \mathrm{~mm}$ broad by $63 \mathrm{~mm}$ thick, weighing $275 \mathrm{~g}$ on average, with adherent skin of intermediate thickness, relatively free of surface disease, flesh orange, juicy but susceptible to jelly seed, with very little fiber near the skin, not objectionable, and some near the stone, sweet and agreeable in taste, of good quality. Seed polyembryonic in a large $(38.5 \mathrm{~g})$ stone. Midseason.

Gohabunder.-See Pairi.

Golek.-Poor-quality yellow mango. Origin: Indonesia. Tree: moderately vigorous with upright, open canopy. Fruit: greenishyellow with an orange overlay and prominent white dots, oblong with rounded base, $95-125 \mathrm{~mm}$ long by $60-80 \mathrm{~mm}$ broad by $55-65 \mathrm{~mm}$ thick, weighing 200-365 g, skin thin, tough and easily separated, flesh soft and juicy with abundant fiber (not objectionable), deep yellow, sweet, insipid with mild aroma, of poor to fair quality. Seed polyembryonic in a large, woody stone with abundant fine fiber. Midseason.

Grape.-See Pairi.

Gundu.-See Alphonso.

Hadialaziz.-See Langra.

Hajipur Langra.-See Langra.

Haphus.-See Alphonso.

Hardoi.-See Langra.

Harumanis.-See Arumanis.

Hiralal Bombai.-See Bombay Green.

Julie (St. Julienne).—Unique tasting mango preferred by many West Indians, and exported to the London market. Origin: Caribbean. Tree: compact (quite dwarfy in Florida), with a dense canopy. Fruit: greenish-yellow with a light pink to maroon blush and numerous small white dots, rounded with flattened apex, pronouncedly compressed laterally, $70-95 \mathrm{~mm}$ long by $40-75 \mathrm{~mm}$ broad by $20-55 \mathrm{~mm}$ thick, weighing 200-325 g with a thin, tender skin and soft, melting juicy flesh with scanty fiber, spicy flavor with a strong, pleasant aroma, of good quality. Seed monoembryonic in a thin, papery stone. Midseason, regular producer of small crops. The fruit is often severely infected with anthracnose disease (Colletotrichum gloeosporioides Penz.).

Kagdi.-See Alphonso.

Kali Bombai.-See Bombay Green.

Kallamai.-See Totapuri.

Kensington (Bowen, Kensington Pride).- The most popular cultivar in Australian markets. Origin: Australia. Tree: large, vigorous with spreading canopy. Fruit: yellow with an orange-red blush on the shoulder, round-ovate with flattened base, with a slight beak, 105-130 $\mathrm{mm}$ long by $85-96 \mathrm{~mm}$ broad by $75-85 \mathrm{~mm}$ thick, weighing $350-750$ $\mathrm{g}$, skin thick, tender and adherent, flesh soft and juicy, with moderate to little fiber, yellow, sweet with a characteristic flavor, bears well. Unusually susceptible locally, in Florida, to damage by red-banded thrips [Selenothrips rubricinctus (Giard)], and may be killed by this pest without adequate treatment. Moderately susceptible to anthracnose and bacterial spot (Xanthomonas campestris pv. Mangiferae indicae).

Kensington Pride.-See Kensington.

Khader.-See Alphonso.

Khader Pasand.-See Alphonso.

Kharaji.-See Chausa.

Killi (Gillig).-See Totapuri.

Kyo Savoy.-Mango often consumed green. Origin: Thailand. Tree: large, vigorous, with open canopy made up of long branches. Fruit: green when harvested (before the ripening process begins), turning to greenish-yellow, oblong, 115-125 mm long by 55-65 mm broad by 50-60 mm thick, weighing 230-340 g, skin thin, tender and adherent, flesh medium-firm, tender and not very juicy with no fiber, pale yellow, very sweet with insipid taste and mild, pleasant aroma, of fair to good quality. Seed highly polyembryonic in a medium-thin stone. Regular producer.

Laile Alipur.-See Bombay Green.

Langarhi._See Langra.

Langra Faquirwala.-See Langra.

Langra (Darbhanga, David Ford, Hadialaziz, Hajipur Langra, Hardoi, Langarhi, Langra Faquirwala, Sylhet, Tikari).--Early to midseason mango with good quality. Tree: moderately vigorous, forming a dense canopy. Fruit: greenish yellow with medium to big dark green dots, ovalish-oblong, $80-105 \mathrm{~mm}$ long by $65-75 \mathrm{~mm}$ broad by $60-70 \mathrm{~mm}$ thick, weighing $235-375 \mathrm{~g}$, skin medium-smooth, thick, flesh firm to soft, fiberless, lemon yellow, very sweet with strong, pleasant aroma, juice moderately abundant, quality very good. Seed monoembryonic in a medium-sized, flattened stone covered with dense, short and soft fibers.

Mabrouka.-Cultivated in Egypt, and marketed in Eastern Europe some years ago. Origin: said to be from India. Tree: strong and sturdy. Fruit: a beautiful deep yellow with an orange to red blush and small, light yellow smooth dots, large, ovate-oblong with a pronounced beak; convex side rounded, a shallow stem-end cavity and a rounded apex, $125 \mathrm{~mm}$ long by $85 \mathrm{~mm}$ broad by $82 \mathrm{~mm}$ thick, weighing $480 \mathrm{~g}$ on average, with thick, nonadherent skin relatively free of surface disease, flesh yellow, firm, and juicy with abundant fiber near the skin and abundant long fiber near the stone, none objectionable, of acceptable quality with a moderately agreeable taste. Seed monoembryonic in a moderately large $(51 \mathrm{~g})$ stone. Late midseason, high-yielding. Said to ship well.

Madoe.-See Madu.

Madu (Madoe).-Midseason mango with alternate production. Origin: Indonesia. Tree: moderately vigorous with dense, rounded canopy. Fruit: light greenish yellow, oblong with rounded base, of moderate size, weighing 240-385 g, flesh soft, tender and juicy, with much fiber, yellow, weakly aromatic and sweet, of poor to fair quality. Seed polyembryonic in a large, woody stone. Name means "honey."

Malda.-See Bombay Green.

Mallika.-Midseason mango with excellent quality. Origin: India, from crossing of Neelum and Dashehari. Tree: moderately vigorous dwarf with dense canopy. Fruit: bright yellow with no blush and numerous light yellow dots; oblong with rounded base, $100-120 \mathrm{~mm}$ long by $65-75 \mathrm{~mm}$ broad by $50-55 \mathrm{~mm}$ thick, weighing $280-450 \mathrm{~g}$; skin thick, tough, and easily separating; flesh soft, tender, and juicy with little fiber, deep yellow to orange, rich, strongly aromatic and sweet, of excellent quality. Seed monoembryonic in a medium thick, woody stone. Midseason, irregular producer.

Manzanillo-Núñez.-Heavy bearer with fruit that stores and ships well. Origin: Mexico. Tree: large, of medium vigor with upright canopy. Fruit: yellowish-orange with $75 \%$ of its surface blushed an intense dark red with numerous dots, oval with moderately flattened base, averaging $120 \mathrm{~mm}$ long by $100 \mathrm{~mm}$ broad by $75 \mathrm{~mm}$ thick and $660 \mathrm{~g}$ weight, flesh low in fiber, slightly subacid and very palatable, quality high. Seed monoembryonic in a relatively small stone. Season early but spread over a 60 -day harvest period. Fruits without pronounced alternation.

Mukku.-See Totapuri.

Nadusalai.-See Pairi.

Naomi.-A red-skinned mango. Origin: Israel; open-pollinated seedling of Palmer; patented. Tree: medium-sized and fairly upright. Fruit: an attractive red, oblong, of uniform size, weighing on average $450 \mathrm{~g}$, skin smooth and thin, flesh tender, juicy and nearly fiberless, yellow, mild and moderately sweet, with a weak pleasant aroma, of good quality. Seed monoembryonic.

Neelum.-Late, heavy-bearing mango. Origin: India. Tree: moderately vigorous, with small, compact canopy. Fruit: bright yellow with no blush and numerous small white dots, oval with flattened or slightly rounded base, $95-110 \mathrm{~mm}$ long by $75-85 \mathrm{~mm}$ broad by $60-65$ mm thick, weighing 230-300 g; skin thick, tender, and easily separating; flesh soft, melting and juicy with no fiber, deep yellow, mild and sweet with a delightfully pleasant aroma, of good to excellent quality. 
Seed monoembryonic in a medium-thick, woody stone.

Nuwun Chan.-Mango often consumed green. Origin: Thailand. Tree: moderately vigorous, small, upright with a dense canopy. Fruit: greenish-yellow with pink to red blush, numerous small green dots, long and slender with a flattened base, $160-180 \mathrm{~mm}$ long by $70-80 \mathrm{~mm}$ broad by $60-65 \mathrm{~mm}$ thick, weighing $340-500 \mathrm{~g}$; skin thick, tough and easily separating, flesh soft, melting, juicy with little fiber, pale yellow, mild and sweet with a faint, pleasant aroma, of good eating quality. Seed polyembryonic in a thick, woody stone. Early, regular bearer.

Paheri.-See Pairi.

Pairi (Gohabunder, Grape, Nadusalai, Paheri, Pairie, Peter, Peter Pasand, Raspuri, Yerra Goa).-A delicious yellow mango. Origin: India, but later introd. to Florida, Hawaii, and Egypt. Tree: moderately vigorous, forming a dense, rounded canopy. Fruit: medium-sized, green to yellow with bright red blush, roundish, skin smooth, thick, flesh golden-yellow, slightly juicy, fiberless, with a delicious subacid taste, of excellent quality. The monoembryonic seed is in a thick, woody stone covered with short, bristly fiber.

Pairie.-See Pairi.

Peter.-See Bombay Green.

Peter.-See Pairi.

Peter Pasand.-See Pairi.

Raspuri.-See Pairi.

Rosa.-One of the most important cultivars in Brazil's Federal District and one of the best-known cultivars in Brazil. Origin: Brazil. Tree: medium-sized, of slow growth with rounded canopy. Fruit: yellow to rose-red on the side exposed to the sun, oblong-cordiform, medium-sized, skin thick and smooth, flesh firm and moderately juicy, fibrous, golden-yellow, moderately sweet with turpentine aroma, of ordinary quality, susceptible to anthracnose disease. Seed polyembryonic, in a small, oblong stone. Midseason to late. Used for juice as well as fresh consumption.

Samar Bahisht Chausa.-See Chausa.

Sandersha.-See Totapuri.

Sarauli.-See Bombay Green.

Sheeri-Dhan.-See Bombay Green.

St. Julienne.-See Julie.

Sylhet.-See Langra.

Taimour.-High-quality orange-fleshed mango. Origin: Egypt. Tree: vigorous, upright. Fruit: large, dark green with large, light brown dots, smooth in texture, ovate-oblong in shape with a shallow stem-end cavity, rounded apex without beak, $128 \mathrm{~mm}$ long by $84 \mathrm{~mm}$ broad by $80 \mathrm{~mm}$ thick, weighing $500 \mathrm{~g}$, with nonadherent skin of intermediate thickness, quite free from surface disease; flesh orange, firm (free of jelly seed) and juicy with a few long fibers near the skin and abundant fine fiber near the stone, not objectionable, of a delightfully rich, sweet taste, of excellent quality, outstanding among mangos. Seed polyembryonic in a thin, medium-sized (50 g) stone. Season late.

Thevadimuthi.-See Totapuri.

Tikari.-See Langra.

Totapuri (Bangalora, Collector, Kallamai, Killi(Gillig), Mukku, Sandersha, Thevadimuthi).-_Large, late yellow mango. Origin: India. Imported to Florida twice, as Sandersha in 1901 and Totapuri in the early 1960s. The seed parent of Anderson and Brooks, which itself is the seed parent of Kent. Called Totapuri in Bangalore and Bangalora in much of the rest of India. Tree: medium-sized, vigorous, spreading with open canopy. Fruit: greenish-yellow with a pink blush and a few small white dots, oblong, base rounded, apex rounded to bluntly pointed with a large beak, $175-200 \mathrm{~mm}$ long by $90-115 \mathrm{~mm}$ broad by 85-105 mm thick, weighing 800-1100 g, skin thick, tough and adherent, flesh firm and medium juicy, with abundant fiber, lemonyellow, rich and spicy with a weak, somewhat repugnant aroma, of poor to fair quality; often used for cooking. Seed monoembryonic in a thin, papery stone. Late midseason, productive and regular bearing. Fruit cracks when exposed to heavy rains at ripening time.

Vallenato.-Early midseason mango of good quality. Origin: Colombia. Tree: vigorous with upright, dense canopy. Fruit: bright yellow, with crimson blush, oblong with flattened base, $80-90 \mathrm{~mm}$ long by $70-80 \mathrm{~mm}$ broad by $60-70 \mathrm{~mm}$ thick, weighing $190-340 \mathrm{~g}$, skin thick, tough and adherent, flesh firm, juicy with abundant fine fiber (not objectionable), pale yellow, mild and sweet with a strong, pleasant aroma, of good to excellent quality. Seed monoembryonic.

Yerra Goa.-See Pairi.

\section{NECTARINE}

Jerome L. Frecon

Dept. of Agricultural and Resource Management Agents, Rutgers Cooperative Extension New Brunswick, N.J.

Charles E. Johnson Dept. of Horticulture, Louisiana State Univ., Baton Rouge

Arctic Gold.-A firm white-fleshed nectarine. Origin: Modesto, Calif., by Chris F., Gary N., and Grant G. Zaiger. Introd. 1995. USPP 9406 As.signed to Zaiger Genetics. Fruit: ovate, medium large, 80\% bright red blush over white skin. Flesh melting, very firm, white, freestone, low acid, subject to stem pulling, excellent eating quality. Tree: upright, vigorous, productive. Flowers large, showy, pink. Leaf glands unknown, 800-900 chilling hours.

AC Harflame (Harflame).-An early-season, red-skinned nectarine. Origin: Harrow, Ontario, Canada, by R.E.C. Layne, Agriculture Canada. Fantasia x H7343017 (=Starks Delicious X Hardired). Tested as HW107. Plant protection pending under Canadian Plant Breeder's Rights. Fruit: globose to ovate, medium large, bright red blush over $80 \%$ to $90 \%$ of glossy smooth surface. Flesh; yellow, freestone. Ripens 5 days before Redhaven. Tree: flowers large, pink, showy. Leaf glands reniform. Upright spreading, vigorous, medium productive. Resistant to bacterial spot.

Crystal Belle.-A very early-season, attractive, white-fleshed nectarine. Origin: Sainte-Vite, France, by Jean L. Escande. 1S2/4 X Snowqueen. Introd. in 1997. USPP 9643. Fruit: globose to obovate, medium. Covered with a $90 \%$ bright red blush. Flesh; melting, firm, white, medium fine, clingstone, good aromatic flavor. Ripening 4 weeks before Redhaven and a week before Arctic Glo. Tree: flowers pink, medium large, showy. Leaf glands reniform. Upright to upright spreading, vigorous, productive. Susceptible to bacterial spot.

Crystal Red.-An early-midseason, white-fleshed nectarine. Origin: Sainte-Vite, France, by Jean L. Escande. 481 x Snowqueen. Introd. in 1997. USPP 9099. Fruit: globose to oblong, medium large, covered with an $80 \%$ to $90 \%$ bright pinkish-red blush. Flesh; melting, white, firm, moderately fine textured, semi-freestone, sweet aromatic flavor. Ripens 1 week before Redhaven. Tree: flowers pink, large, showy. Leaf glands reniform. Upright-spreading, vigorous, productive. Susceptible to bacterial spot.

\section{Harflame.-See AC Harflame.}

July Pearl._A firm, white clingstone nectarine. Origin: LeGrand, Calif., by L.G. Bradford and N.G. Bradford. Summer Bright x June Pearl. USPP 10293. Introd. 1997. Fruit: Globose uniform symmetrical, large, nearly full red blush. Flesh melting, white, subacid, medium firm, clingstone. Ripens 7-14 July in LeGrand. Tree: Flowers large, moderate pink, showy. Leaf glands reniform, alternate. Upright and dense, vigorous, very productive.

Juneprincess.-An attractive, firm-fleshed, early-season nectarine adapted to the southeastern United States. Origin: Byron, Ga., USDA-ARS, by W.R. Okie. $\mathrm{F}_{2}$ seedling of Flamekist $x$ P12-42. Selected in 1980. Tested as BY78AN38. Introd. in 1997. Fruit: globose-oblong, large, $80 \%$ to $90 \%$ attractive red blush with a yellow ground color. Flesh; melting, yellow with some red at pit cavity, freestone, firm, good texture, good flavor. Ripens 1 week before RedHaven. More tolerant of cracking and rot than Summer Beaut. Tree: flowers large, showy, pink, self-fertile. Leaf glands reniform. Upright spreading, vigorous and productive. Moderately tolerant of bacterial spot. Chilling requirement $850 \mathrm{~h}$.

Scarlet Sun.-A large, attractive, red-skinned nectarine. Origin: A chance seedling found by T.O. Chamberlain in the nursery of H.P. Metzler \& Sons in DelRay, Calif. Introd. in 1996. USPP 9264. Assigned to Metropolitan Life Insurance Co., DelRay, Calif. Fruit: ovoid to slightly ovate, large to very large, $80 \%$ to $100 \%$ of surface 
covered with bright red blush. Flesh orange-yellow, firm, melting but slow softening, some red around pit, medium acidic, clingstone. Ripens 15-25 June near DelRay, Calif., and near Redhaven in New Jersey. Tree: flowers large, showy, deep pink. Leaf glands reniform, opposite to alternate. Spreading to slightly upright, vigorous, productive. Susceptible to bacterial spot.

Stark ${ }^{\circledR}$ Encore.-A very late yellow-fleshed nectarine. Origin: a limb mutation of Encore peach found in the orchard of Bill Elliott of Fairfield, Ill. Introd. in 1996. USPP 8949. Assigned to Stark Bros. Nurseries. Fruit: globose to oval, large, covered with a purplish-red mottled blush over $40 \%$ to $50 \%$ of the surface. Melting flesh, yellow, firm, subacid, freestone. Ripens 2 weeks after Redgold with Encore peach. Tree: flowers small, nonshowy, pinkish-red. Leaf glands reniform. Very upright; vigorous, very productive. Susceptible to bacterial spot.

Stark $^{\circledR}$ Ovation.-A late yellow-fleshed nectarine. Origin: a chance seedling found in the Zenith Pollack Orchards in Mason, Mich. Introd. in 1997. USPP 9263. Assigned to Stark Bros. Nurseries, Louisiana, Mo. Fruit: oval, large, covered with $70 \%$ to $80 \%$ light red color. Melting flesh, yellow, firm, juicy, subacid, freestone. Ripens 10 days after Redgold. Tree: flowers large, showy, rich pink. Leaf glands reniform. Upright, vigorous and productive. Susceptible to bacterial spot.

\section{PEACH}

\section{Jerome L. Frecon \\ Dept. of Agricultural and Resource Management Agents, Rutgers Cooperative Extension New Brunswick, N.J. \\ Charles E. Johnson \\ Dept. of Horticulture, Louisiana State Univ., Baton Rouge}

AC Harrow Dawn (Harrow Dawn).-A cold-hardy, diseaseresistant peach for early season. Origin: Harrow, Ontario, Agriculture Canada, by R.E.C. Layne. Cresthaven x Harbinger. Selected in 1974; tested as HW254; introd. in 1996. Protected under Canadian Plant Breeder's Rights Act. Fruit: medium; $6.3 \mathrm{~cm}$ diameter; round, firm; yellow flesh; $80 \%$ red blush; semi-free; ripens 42 days before Elberta. Tree: winter hardy; similar to Harrow Diamond in hardiness; tolerant to perennial canker; reniform leaf glands; flower nonshowy. Chilling requirement estimated at $850 \mathrm{~h}$.

AC Harrow Fair (Harrow Fair).-A midseason, cold-hardy peach. Origin: Harrow, Ontario, Agriculture Canada, by R.E.C. Layne. Biscoe x V55061 [=Redskin x Kalehaven]. Selected in 1982; tested as HW259; introd. 1996. Protected under Canadian Plant Breeder's Rights Act. Fruit: medium; $6.8 \mathrm{~cm}$ diameter; obovate; $80 \%$ red blush; freestone; yellow flesh; ripens 6 days after Redhaven. Tree: vigorous; cold hardy; resistant to bacterial spot; reniform leaf gland; flowers nonshowy. Chilling requirement estimated at $950 \mathrm{~h}$.

Allstar $^{\mathrm{TM}}$.- An attractive yellow-fleshed peach ripening 2 weeks after Redhaven. Origin: Coloma, Mich., by Annette and Randy Bjorge. Fayette $x$ Newhaven. Tested as FA 80. Introd. in 1997. USPP 10549 assigned to International Plant Management, Lawrence, Mich. Fruit: globose, medium large, covered with a $90 \%$ to $100 \%$ red blush. Flesh: melting, yellow-orange, firm, fine-textured, freestone. Flavor is excellent with medium acid. Ripens 14 to 17 days after Redhaven. Tree: flowers dark pink, small, moderately showy. Leaf glands globose. Upright, very vigorous, very productive. Resistant to bacterial spot. Chilling requirement estimated at $750 \mathrm{~h}$.

Autumnprince.-A very late ripening peach. Origin: Byron, Ga., USDA-ARS, by W.R. Okie. O'Henry x BY79P670 (BY4-711 x BY3877). Selected in 1986; tested as B Y85P325; introd. in 1997. Fruit: large; round; $8 \mathrm{~cm}$ diameter; $60 \%$ dull red blush; freestone; yellow flesh; ripens 7 weeks after Elberta. Tree: vigorous; moderate resistance to bacterial spot; flower large, showy, self-fertile; reniform leaf glands. Chilling requirement $800 \mathrm{~h}$.

Blazeprince.-A very firm, midseason peach. Origin: Byron, Ga., USDA-ARS, by W.R. Okie. Open-pollinated seedling of BY81P2840 (=O.P. seedling of O'Henry). Selected in 1986; tested as BY84P3350; introd. in 1997. Fruit: large; $8 \mathrm{~cm}$ in diameter; yellow flesh; freestone, round; with $90 \%$ red blush; firm; ripens between Harvester and Redglobe. Tree: vigorous and productive; moderately susceptible to bacterial spot; flower large, showy, pink, and selffertile; reniform leaf glands. Chilling requirement $850 \mathrm{~h}$.

Blazingstar ${ }^{\mathrm{TM}}$.-An attractive yellow-fleshed peach ripening after Redhaven. Origin: Coloma, Mich., by Annette and Randy Bjorge. Fayette X Newhaven. Tested as FA 12. Introd. in 1997. USPP 10555 assigned to International Plant Management, Lawrence, Mich. Fruit: Globose to slightly oblate, large, covered with $90 \%$ to $100 \%$ bright red blush. Flesh melting, yellow-orange, firm, fine textured, excellent flavor. Ripens 5 days after Redhaven. Tree: Flowers dark pinkish red, medium size, medium showy. Leaf glands globose. Upright spreading, vigorous, very productive. Resistant to bacterial spot.

Blushingstar ${ }^{\mathrm{TM}}$ - - A firm white-fleshed peach ripening near Cresthaven. Origin: Coloma, Mich., by Annette and Randy Bjorge. Fayette $x$ Newhaven. Tested as FA 18. Introd. in 1997. USPP 10554 assigned to International Plant Management, Lawrence, Mich. Fruit: Globose, medium large, covered with a $80 \%$ to $90 \%$ dark pinkish-red blush over a cream undercolor. Ripens 19-21 days after Redhaven. Tree: Flowers dark pinkish-red, medium size, medium showy. Leaf glands reniform. Upright spreading, vigorous, productive. Susceptible to bacterial spot. Chilling requirement $750 \mathrm{~h}$.

Coralstar ${ }^{\mathrm{TM}}$.-A midseason, attractive, yellow-fleshed peach. Origin: Coloma, Mich., by Annette and Randy Bjorge. Fayette $x$ Newhaven. Tested as FA 59. Introd. in 1997. USPPAF. Fruit: globose, medium large, covered with a $70 \%$ to $80 \%$ red blush. Flesh; melting, yellow, firm, freestone, good quality. Ripens 10-14 days after Redhaven. Tree: flowers dark pink, medium size, nonshowy. Leaf glands reniform. Upright spreading, medium vigor, and very productive. Resistant to bacterial spot. Chilling requirement $950 \mathrm{~h}$.

Flamin Fury ${ }^{\circledR}$ P.F. 1.-A very early-season, yellow-fleshed peach. Origin: Coloma, Mich., by P. Friday. Garnet Beauty x Cardinal. Introd. 1995. USPP 9129. Fruit: Globose to ovate, medium sized, skin covered with a $70 \%$ red blush. Flesh; melting, yellow, medium firm, semi-clingstone, good overall quality. Ripening $31 / 2$ weeks before Redhaven. Tree: flowers pink, small, nonshowy. Leaf glands reniform and opposite. Upright, medium vigor, productive, and winter hardy. Tolerant to bacterial spot. Chilling requirement $750-850 \mathrm{~h}$.

Flamin Fury ${ }^{\circledR}$ P.F. 5B.-A firm yellow-fleshed peach ripening before Garnet Beauty. Origin: Coloma, Mich., by P. Friday. Unknown controlled cross. Introd. in 1997. USPP 9850. Fruit: globose, medium large, skin covered with $80 \%$ red blush. Flesh; melting, dull yellow, medium firm, semi-clingstone with good quality. Ripens $21 / 2$ to 3 weeks before Redhaven. Tree: flowers medium large, pink, moderately showy. Leaf glands reniform and opposite. Upright, medium vigor, productive and winter hardy. Tolerant to bacterial spot. Chilling requirement $750 \mathrm{~h}$.

Flamin Fury ${ }^{\circledR}$ P.F. 7.-A firm yellow-fleshed peach ripening with Garnet Beauty. Origin: Coloma, Mich., by P. Friday. Unknown controlled cross. Introd. in 1998. USPP 10490. Fruit: globose, medium to large, skin covered with $80 \%$ red blush. Flesh; melting, yellow, firm, clingstone, fine textured. Ripening 10 days to 2 weeks before Redhaven with Garnet Beauty. Tree: flowers pink, medium, somewhat showy. Leaf glands reniform and few. Spreading with strong right angles, medium vigor, very productive and winter hardy. Chilling requirement $750 \mathrm{~h}$.

Flamin Fury ${ }^{\circledR}$ P.F. 12B.-An attractive yellow-fleshed peach ripening in Redhaven season. Origin: Coloma, Mich., by P. Friday. Unknown controlled cross. Introd. in 1998. USPPAF. Fruit: globose, large, skin covered with $70 \%$ red blush. Flesh; melting yellow, firm, fine textured, with good quality. Ripens on 7 Aug. in Coloma with Redhaven. Tree: flowers nonshowy, dark pink, small. Leaf glands very small and reniform. Moderately vigorous semi-dwarf, upright spreading, productive and winter hardy. Chilling requirement $750 \mathrm{~h}$.

Flamin Fury ${ }^{\circledR}$ P.F. 15A.-An attractive yellow-fleshed peach ripening just after Redhaven. Origin: Coloma, Mich., by P. Friday. Unknown controlled cross. Introd. in 1993. USPP 8978. Fruit: globose, large, covered with $80 \%$ red over yellow ground color. Flesh; melting, yellow, firm, freestone, fine-textured, of good overall quality. Ripens 5 days after Redhaven. Tree: flowers reddish pink, medium size, partially showy. Upright, medium vigor, productive. Tolerant to 
bacterial spot. Chilling requirement $750-800 \mathrm{~h}$.

Flamin Fury ${ }^{\circledR}$ P.F. 17.-Coloma, Mich., by P. Friday. Unknown controlled cross. Introd. in 1993. USPP 8169. Fruit: ovate to oblong, large, skin covered with a $60 \%$ to $70 \%$ red blush. Flesh; melting, yellow, firm, fine textured, freestone, and good overall quality. Ripens 8-12 days after Redhaven. Tree: flowers partially showy, pink, medium. Leaf glands reniform and alternate. Upright, medium vigor, productive, and winter hardy. Susceptible to bacterial spot. Chilling requirement $700 \mathrm{~h}$.

Flamin Fury ${ }^{\circledR}$ P.F. 20-007.-A large, firm, yellow-fleshed peach ripening in Redkist season. Origin: Coloma, Mich., by P. Friday. Unknown controlled cross. Introd. in 1998. USPPAF. Fruit: globose, large, skin covered with a $60 \%$ to $80 \%$ red blush. Flesh; melting, yellow, firm, freestone, fine textured, good quality. Ripens between Loring and near Redkist. Tree: flowers dark pink, small, nonshowy. Leaf glands reniform, very small. Spreading with right angle branching, vigorous, productive and winter hardy. Chilling requirement 750 h.

Flamin Fury ${ }^{\circledR}$ P.F. 23.-A late-season, yellow-fleshed, attractive peach variety. Origin: Coloma, Mich., by P. Friday. Unknown controlled cross. Introd. in 1993. USPP 8164. Fruit: globose, large, skin covered with an $80 \%$ dark red blush. Flesh melting, yellow, firm, freestone, fine textured, overall good quality. Ripening $21 / 2$ weeks after Redhaven. Tree: flowers pink, medium, partially showy. Leaf glands reniform. Spreading, medium vigor, productive and winter hardy. Tolerant to bacterial spot. Chilling requirement $650-700 \mathrm{~h}$.

Flamin Fury ${ }^{\circledR}$ P.F. 24-007.-A large, attractive, late midseason, yellow-fleshed variety. Origin: Coloma, Mich., by P. Friday. Unknown controlled cross. Introd. in 1998. USPP 9895. Fruit: globose, large to very large. Covered with a $80 \%$ red blush. Flesh melting, yellow, firm, fine textured, good overall quality. Ripens 3 weeks after Redhaven. Tree: flowers pink, medium size, partially showy. Leaf glands inconspicuous to very small. Upright, vigorous, productive.

Flamin Fury ${ }^{\circledR}$ P.F. 25.-A firm, late-season, yellow-fleshed peach. Origin: Coloma, Mich., by P. Friday. Unknown controlled cross. Introd. in 1997. USPP 9940. Fruit: globose, large, skin covered with a $70 \%$ dull red color. Flesh melting, yellow, firm, freestone, fine textured, good quality. Ripening 3 to $31 / 2$ weeks after Redhaven. Tree: flowers pink, medium, nonshowy. Leaf glands reniform. Upright, medium vigor, very productive and winter hardy.

Flamin Fury ${ }^{\circledR}$ P.F. 27A.-An attractive, late-season, yellowfleshed peach. Origin: Coloma, Mich., by P. Friday. Unknown controlled cross. Introd. in 1997. USPP 9939. Fruit: globose, large to very large. Covered with $60 \%$ to $80 \%$ red blush with a yellow ground color. Flesh melting, yellow, firm, freestone, excellent flavor, good overall quality. Ripens 4 weeks after Redhaven. Tree: flowers dark pink, medium, partially showy. Leaf glands reniform. Upright spreading, medium vigor, very vigorous. Susceptible to bacterial spot. Chilling requirement $750 \mathrm{~h}$.

Glowingstar ${ }^{\mathrm{TM}}$.- An attractive yellow-fleshed peach ripening 30 days after Redhaven. Origin: Coloma, Mich., by Annette and Randy Bjorge. Fayette x Newhaven. Tested as FA 17. Introd. in 1997. USPP 10556. Assigned to International Plant Management, Lawrence, Mich. Fruit: ovate, large, covered with a $80 \%$ to $90 \%$ dark red blush overlaid with a soft stripe. Flesh; melting, yellow-orange, firm, freestone, fine textured. Good flavor. Ripens 27 to 32 days after Redhaven. Tree: flowers dark pink, medium, medium showy. Leaf glands globose. Upright and open, very vigorous, very productive. Resistant to bacterial spot.

Glenglo.-An attractive, early-season, yellow-fleshed peach. Origin: A chance seedling found by Glen Welsh in his Loring block in Martinsburg, W.Va. Introd. in 1996. USPP 10652. Assigned to Adams County Nursery, Aspers, Pa. Fruit: globose, medium large, covered with a orange-red blush over $60 \%$ to $70 \%$ of surface. Flesh melting, yellow, good quality, semi-freestone. Ripening 10 days to 2 weeks before Redhaven. Tree: flowers medium to large, showy, pink. No leaf glands.

Harrow Dawn.-See AC Harrow Dawn.

Harrow Fair.-See AC Harrow Fair.

Pretty Lady._-A large freestone peach of high color. Origin: a limb mutation of Summer Lady found at Fowler Orchards, Newcastle,
Calif. Introd. 1996. USPP 9594. Assigned to Fowler Nurseries, Newcastle, Calif. Fruit: globose, large to very large, covered with a $60 \%$ to $90 \%$ deep red blush color. Flesh melting, orange (apricot)yellow, freestone, juicy, firm, with exceptional quality. Ripens 5-20 Aug. in Reedley, Calif. Tree: flowers large, showy, deep pink. Leaf glands reniform. Upright to moderately spreading, vigorous, productive in California. Chilling requirement $600 \mathrm{~h}$.

Redstar $^{\mathrm{TM}}$.- An attractive peach ripening with Redhaven. Origin: Coloma, Mich., by Annette and Randy Bjorge. Open-pollinated seedling of Newhaven. Tested as FA 52. Introd. in 1997. USPP 10546, assigned to International Plant Management, Lawrence, Mich. Fruit: globose, medium large, covered with a $70 \%$ to $80 \%$ red blush with mottled stripe. Flesh melting, yellow, firm, fine textured, semi-freestone, good quality. Ripens with Redhaven peach. Tree: flowers light pink, small, nonshowy. Leaf glands reniform. Spreading, vigorous, very productive. Resistant to bacterial spot. Chilling requirement 1000 h.

Risingstar $^{\mathrm{TM}}$.-An early-season, yellow-fleshed peach. Origin: Coloma, Mich., by Annette and Randy Bjorge. Newhaven x Jim Dandee. Tested as FA 47. Introd. in 1997. USPP 10545 assigned to International Plant Management, Lawrence, Mich. Fruit: ovate, medium, covered with a $90 \%$ to $100 \%$ red blush. Flesh; melting, yellow, medium firm, clingstone, good quality. Ripens 7 to 12 days before Redhaven. Tree: flowers dark pinkish-red, medium size, medium showy. Leaf glands globose. Very spreading and weeping, vigorous, and productive. Resistant to bacterial spot. Chilling requirement 900 h.

Royal Lady.-A very firm yellow-fleshed, late-season peach. Origin: a limb mutation of Elegant Lady in Reedley, Calif. Introd. in 1993. USPP 8211 assigned to Fowler Nurseries, Newcastle, Calif. Fruit: globose, large, covered with a $60 \%$ to $90 \%$ red blush. Flesh amber-yellow, melting, very firm, freestone. Ripens from 20 July to 2 Aug. in Reedley. Tree: flowers small, nonshowy, light pink. Leaf glands reniform and numerous. Upright to spreading, moderately vigorous, productive.

Rubyprince.-An attractive, early-season peach. Origin: Byron, Ga., USDA-ARS, by W.R. Okie. Fireprince X BY78GN55 (Redgold X Durbin). Selected in 1984; tested as BY82P5750; introd. in 1997. Fruit: round; $7 \mathrm{~cm}$ diameter; firm, $90 \%$ bright red; yellow flesh; clingstone. Tree: vigorous; moderate resistance to bacterial spot; flower showy self-fertile; reniform leaf glands. Chilling requirement $850 \mathrm{~h}$.

Southern Pearl.-A midseason white-flesh peach. Origin: Byron, Ga., USDA-ARS, by W.R. Okie. Open-pollinated seedling from Roseprincess. Selected in 1986; tested as BY84P1807; introd. 1997. Fruit: large; $8 \mathrm{~cm}$ diameter; round; white flesh; semi-freestone; ripens 6 weeks before Elberta; $70 \%$ bright red with streaks when ripe. Tree: vigorous; globose leaf glands; moderate resistance to bacterial spot; flowers large showy and self-fertile. Chilling requirement $650 \mathrm{~h}$.

Spring Gem.-A large, early-ripening peach. Origin: Fresno, Calif., USDA-ARS, by D.W. Ramming and O. Tanner.P113-98[=PI0062 op=Redking op.] x FV9-164 [(=FV89-14 x Springtime)]; FV89-14 $=[$ FV15-4 $\times$ Fireglow $] ;$ FV15-4 $=$ Fireglow $\times$ Hiley. Selected in 1983; tested as P46-12; introd. in 1997. Fruit: $7.5 \mathrm{~cm}$ diameter; round; 70\% red blush; yellow flesh; semi-freestone; melting; ripens between Springcrest and Gemfree. Tree: flowers showy, self-fertile; reniform leaf glands. Chilling requirement $700 \mathrm{~h}$.

Springprince.-An early-ripening peach. Origin: Byron, Ga., USDA-ARS, by W.R. Okie. Open-pollinated seedling of Springcrest. Selected in 1984; tested as BY82P5972; introd. in 1998. Fruit: medium large; $6 \mathrm{~cm}$ diameter; $90 \%$ bright red blush; clingstone; firm; nonmelting flesh; 7 weeks before Elberta. Tree: vigorous; leaf glands globose; moderately susceptible to bacterial spot; flowers large, showy, self-fertile. Chilling requirement $650 \mathrm{~h}$.

Starfire $^{\mathrm{TM}}$-- An attractive yellow-fleshed peach ripening just after Redhaven. Origin: Coloma, Mich., by Annette and Randy Bjorge. Fayette $x$ Newhaven. Tested as FA 11. Introd. in 1997. USPP 10548 assigned to International Plant Management, Lawrence, Mich. Fruit: globose, medium large, covered with a $80 \%$ red blush with a mottled stripe. Flesh melting, yellow-orange, semi-firm, freestone, sweet, mild acid flavor. Ripens 3 days after Redhaven. Tree: flowers 
pink, small, nonshowy. Leaf glands reniform. Moderately spreading, medium vigor, and very productive. Resistant to bacterial spot. Chilling requirement $850 \mathrm{~h}$.

Stark $^{\circledR}$ Saturn.-The first commercial flat or peento peach. Origin: New Brunswick, N.J., by L. Fredric Hough and C.H. Bailey, NJAES at Rutgers Univ. NJ602903(=Golden Globe x R1T6) x Pallas. Tested as NJF2. Introd. in 1980 by J.L. Frecon for Stark Bros. Nurseries. USPP 5123. Fruit: flat or peento type, medium size, covered with an attractive pinkish red color over $50 \%$ to $60 \%$ of the surface. Flesh melting, soft to moderately firm, white, freestone with small globose like seed, juicy, medium acid, excellent, aromatic flavor. Ripens with Redhaven peach. Tree: flower; large, pink, showy. Leaf glands reniform. Spreading, vigorous, very productive tree. Chilling requirement $700 \mathrm{~h}$. Tolerant to bacterial spot.

Summer Breeze ${ }^{\mathrm{TM}}$. - A midseason yellow-fleshed peach. Origin: a chance seedling found in a block of Jerseyqueen at Hollabaugh Bros. Orchards in Biglerville, Pa. Tested as HB 110. Introd. in 1997. USPPAF. Assigned to Adams County Nursery, Aspers, Pa. Fruit: globose, large, a bright red blush covering $75 \%$ of the skin surface. Flesh; melting, yellow, firm, freestone, very good quality. Ripening 15 days after Redhaven. Tree: flowers medium to large, rich pink, showy. Leaf glands reniform 4-6 alternate. Upright spreading tree, vigorous, moderately productive.

Summer Serenade.-A large, productive, early-season, yellowfleshed variety. Origin: a chance seedling found iin the Willmeng Bros. Orchards in Coloma, Mich. Tested as WB258. Introd. in 1997. USPPAF. Assigned to Hilltop Nurseries, Hartford, Mich. Fruit: globose with a prominent suture, large, covered with a mottled to full red blush over $75 \%$ of the surface. Flesh melting, stringy, yellow, moderately firm, of good quality, semi-clingstone, few splits. Tree: flowers light pink, small, nonshowy. Leaf glands reniform. Upright spreading, vigorous, very productive. Tolerant to bacterial spot.

Sureprince.-An early-season, consistent-cropping peach. Origin: Byron, Ga., USDA-ARS, by W.R. Okie. $F_{2}$ of Dixiland $x$ Durbin. Selected in 1983; tested as BY81P1216; introd. in 1998. Fruit: ripens 7 days before Redhaven, round, $7 \mathrm{~cm}$ diameter, $90 \%$ bright red blush, yellow flesh, semi-freestone. Tree: vigorous; flowers large, showy and self-fertile; moderate resistance to bacterial spot; leaf glands absent. Chilling requirement $950 \mathrm{~h}$.

Vinegold.-A nonmelting yellow-fleshed peach developed for canning. Origin: Vineland, Ontario, Horticultural Research Institute of Ontario by N. Miles. NJC95 x Veecling. Tested as V7828160. Introd. in 1994. Fruit: globose, large, limited red blush, attractive. Flesh; yellow, nonmelting clingstone, medium to firm, good quality. Tree: flowers light pink small, nonshowy. Leaf glands reniform. Upright spreading, vigorous, productive. Moderately resistant to bacterial spot. Chilling requirement $850 \mathrm{~h}$.

UF Gold.-A low-chilling-requirement, nonmelting flesh peach for the early fresh market. Origin: Univ. of Florida, Gainesville. Fla. $84-8 \mathrm{C}(=$ Diamante op $) \times$ Fla $9-20 \mathrm{C}[=($ Fla.K5W35 $\times$ NCA2219 $)$ op $]$; Fla.K5W35=Fla. 8-11 $\times$ Kaygold ; NCA2219= NC7130 $(=$ Halehaven x Redskin) $x$ Candor; tested as Fla.90-24C; introd. in 1996. USPPAF. Fruit: nonmelting flesh; firm; round; yellow flesh; $80 \%$ red blush; ripens 5 days before Flordaglo. Tree: resistant to bacterial spot; reniform leaf glands. Chilling requirement $400 \mathrm{~h}$.

\section{PEAR-ASIAN \\ Joseph D. Postman and Kim E. Hummer USDA-ARS National Clonal Germplasm Repository Corvallis, Ore.}

Arirang $^{\mathrm{TM}}$.- -See Danbae.

ASAJU ${ }^{\mathrm{TM}}$.- - See Asio 1.

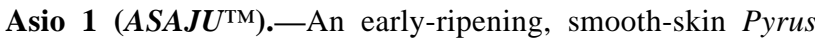
pyrifolia cultivar. Origin: developed by Joel and Ruth Spira, Eugene Konno, and Neil Vincent in Coopersburg, Pa. Open-pollinated seed from Japan planted in 1981. Fruited in 1987. USPP 9835 issued 25 Mar. 1997 to Subarashii Kudamono Co., Coopersburg, Pa. Fruit: medium to large, round, slightly wider than long; stem $\approx 2.5 \mathrm{~cm}$, thicker at the base; cavity shallow, acute; basin deep, wide, with small deciduous calyx; skin bright yellow with prominent tan lenticels; flesh semi-sweet, mild flavor; ripe late August in Coopersburg, Pa., $\approx 2$ weeks earlier than Nijisseiki. Tree: large, vigorous, spreading, consistent, heavy crop; blooms with Nijisseiki, self-infertile.

Asio 2 (JunoSan ${ }^{\mathrm{TM}}$ ). - A midseason, russeted Pyrus pyrifolia cultivar. Origin: Developed by Joel and Ruth Spira, Eugene Konno, and Neil Vincent in Coopersburg, Pa. Open-pollinated seed of Chojuro, planted in 1983. Fruited in 1987. USPP 9827 issued 18 Mar. 1997 to Subarashii Kudamono Co., Coopersburg, Pa. Fruit: large to very large, round like Chojuro; stem $\approx 2.5 \mathrm{~cm}$; cavity shallow, acute; basin moderately wide with deciduous calyx; skin russeted, golden-brown, lighter than Chojuro, with prominent lenticels; flesh white, crisp, juicy, sweet; ripe mid-September in Coopersburg, Pa., $\approx 1$ week later than Chojuro. Tree: open, spreading habit, moderate vigor; consistent, heavy crop; blooms with Chojuro, self-infertile.

Asio 3.-A mid-late season, dark russeted Pyrus pyrifolia cultivar. Origin: Developed by Joel and Ruth Spira, Eugene Konno, and Neil Vincent in Coopersburg, Pa. Open-pollinated seed of Asian Pear Selection No. 6 planted in 1983. Selection No. 6 was grown from open pollinated seed from Japan. Fruited in 1987. USPP 9828 issued 18 Mar. 1997 to Subarashii Kudamono Co., Coopersburg, Pa. Fruit: round, large to v. large, up to $600 \mathrm{~g}$; stem medium length, clubbed; cavity acuminate; basin obtuse with deciduous calyx; skin green, completely covered with dark brown russet, tan lenticels; flesh white, crisp, juicy, semi-sweet, mild flavor, low acid; ripe late September in Coopersburg, Pa. Tree: open, spreading habit, moderate vigor, consistent, heavy crop; blooms midseason, self-infertile.

Asio 4 (SuSan $\left.{ }^{\mathrm{TM}}\right)$. - A late-season, russeted Pyrus pyrifolia cultivar. Origin: Developed by Joel and Ruth Spira, Eugene Konno, and Neil Vincent in Coopersburg, Pa. Open-pollinated seed from Japan planted in 1983. Fruited in 1987. USPP 9822 issued 11 Mar. 1997 to Subarashii Kudamono Co., Coopersburg, Pa. Fruit: ovate, variable, with prominent lobe at calyx end, medium, up to $250 \mathrm{~g}$; stem medium, clubbed, with prominent lenticels; cavity acute; basin narrow with persistent calyx; skin completely russeted, light brown with prominent, raised, tan lenticels; flesh white, crisp, juicy, very sweet, low acid; ripe mid-late October in Coopersburg, Pa., a few days later than Seuri. Tree: dense, vigorous, consistent, heavy crop; self-infertile.

Danbae (Arirang ${ }^{\mathrm{TM}}$, Korean Giant, Olympic).-A late-season, large, russet-skin pear from Korea. Origin: old Korean cultivar, pedigree unknown. Fruit: large; skin completely brown russeted; flesh crisp, juicy, sweet, insipid; ripe late, about 2 weeks after $\mathrm{Ya} \mathrm{Li}$; may show internal problems when stored immediately at $0{ }^{\circ} \mathrm{C}$. Tree: medium cold hardiness, suffers occasional winter injury in Hood River, Ore. The Korean name Danbae means "sweet pear" (bae = pear); 'Arirang' is the Korean word for "mountain" and is also a famous Korean anthem.

JunoSan ${ }^{\mathrm{TM}}$.-See Asio 2.

Korean Giant.-See Danbae.

Olympic.-See Danbae

SuSan ${ }^{\mathrm{TM}}$.-See Asio 4.

\section{PEAR-EUROPEAN}

\section{Joseph D. Postman and Kim E. Hummer USDA-ARS National Clonal Germplasm Repository Corvallis, Ore.}

Biehn (Cinnamon).-A fully russeted, late-ripening sport of Bartlett. Origin: discovered in 1979 as a limb mutation of a Bartlett tree in the orchard of Don and Nancy Biehn near Hood River, Ore. USPP 10325, issued 14 Apr. 1998 to Fowler Nurseries, Newcastle, Calif. Fruit: shape uniform, ovate pyriform, not at long as standard Bartlett, and with a thicker neck; stem short and thick; skin completely russeted, the russet developing early when the fruit is first formed; flesh fine textured and buttery like Bartlett, higher sugar content than Bartlett in limited testing, spicy, slightly cinnamon flavor; ripens with Anjou 2-3 weeks later than Bartlett. Tree: moderately vigorous, similar to Bartlett; bloom period similar to Bartlett.

Bronze Beauty ${ }^{\mathrm{TM}}$ Bosc.-See Wimmers Bosc.

Cinnamon.-See Biehn.

Taylor's Gold Comice.-Russeted sport of Doyenne du Comice 
from New Zealand. Origin: discovered in 1985 by Michael and Wendy King-Turner as a bud mutation of Doyenne du Comice in their orchard in Motueka, New Zealand. USPP 8308 issued 20 July 1993. Fruit: slightly smaller but same shape as standard Comice; skin completely russeted, brown, sometimes with a red blush; flesh fine, melting, juicy like Comice. Tree: vigor, growth habit, and bloom date same as Comice; vegetative budbreak is about a week earlier than Comice.

Wimmers Bosc (Bronze Beauty ${ }^{\mathrm{TM}}$ Bosc).-Uniformly russeted sport of Bosc. Origin: discovered in 1980 by Robert Wimmers in his orchard in Hood River, Ore. A whole-tree mutation in a planting of OP5 Bosc trees planted about 1970. USPP 7485 issued 2 Apr. 1991. Fruit: size and shape same as standard Bosc; skin develops a uniform bronze russet that appears about a month earlier than the russet on Golden Russet Bosc and has a rougher texture, develops russet in "poor russet" areas; ripe $\approx 1$ week later than standard OP-5 Bosc; higher soluble solids. Tree: same as Bosc, large and vigorous.

\section{PEAR-ROOTSTOCK}

\section{Joseph D. Postman and Kim E. Hummer USDA-ARS National Clonal Germplasm Repository Corvallis, Ore.}

Pyrodwarf $^{\mathrm{TM}}$.-See Rhenus 1.

Rhenus 1 (Pyrodwarf ${ }^{\mathrm{TM}}$ ). - A precocious, dwarfing rootstock from Germany. Origin: Cross of Old Home x Bonne Louise made by Helmut Jacob at Geisenheim, Germany, in 1980. North American propagation rights assigned to Tree Connection, Dundee, Ore. USPPAF. Tree: nonsuckering, good compatibility, produces a tree intermediate to Quince A and Quince C, $\approx 40 \%$ the size of a tree on pear seedling rootstock; moderate resistance to fire blight. Found to induce high yield efficiency with Bartlett scions, and to have good anchorage and winter cold hardiness in German trials.

\section{PLUM}

\section{D.W. Ramming \\ USDA Horticultural Crops Research Laboratory Fresno, Calif.}

7-B.-An early-ripening Japanese plum. Origin: near Reedlley, Calif., by Michael Gerawan. Mutation of Red Beaut. USPP 10116 issued 11 Nov. 1997. Fruit: medium, $50 \mathrm{~mm}$ diameter, $51 \mathrm{~mm}$ long; ovate; skin garnet purple; flesh light amber-yellow, firm; semi-cling; matures last week of May to first week of June in central Calif. Resembles Red Beaut. Tree: large, vigorous, spreading, productive; anthers orange-yellow with abundant pollen, self-fruitful.

Bluebyrd.-A high-quality European plum. Origin: in Beltsville, Md., by Harold W. Fogle, released by Ralph Scorza. Open-pollinated seedling of NYH4=unknown origin. Released 20 Mar. 1998. Fruit: 41 $\mathrm{mm}$ diameter, $50 \mathrm{~mm}$ long, 40 to $50 \mathrm{~g}$; skin deep purple; flesh amber, sweet, avg. 20\%SS; slight cling; matures 10 days before Stanley. Tree: upright, self-incompatible, productive.

Blue Gusto.- - A late-ripening, dark-skinned Japanese plum. Origin: in Modesto, Calif., by Chris, Gary, and Grant Zaiger and Leith Gardner. Hybrid of 26GB440= $($ King David X 46G452=[Queen Ann X Casselman $]) \times 105$ GD60 $=($ Friar $\times$ 59GA511 $=[$ Mariposa $\times$ Ebony $])$. USPP 9331 issued 17 Oct. 1995. Fruit: large, $66 \mathrm{~mm}$ diameter, $76 \mathrm{~mm}$ long; ovoid, elongated at apex; skin bluish-black to dull violet; flesh pale yellow, firm; cling; matures second week of August in California. Tree: large, vigorous, upright, productive; pollen white.

Hiromi Red.-A midseason, red-skinned Japanese plum. Origin: in Modesto, Calif., by Chris, Gary, and Grant Zaiger and Leith Gardner. Open-pollinated seedling of 20EB314=Nubiana x Queen Rosa. USPP 9858 issued 15 Apr. 1997. Fruit: large, 63 mm diameter; globose; skin red with small dots; flesh light yellow to yellow, firm; cling; matures 1 week before Queen Rosa, about the third week of June in California. Tree: large, vigorous, upright, productive.

Joanna Red.-A late-season, red-skinned Japanese plum. Origin: in Modesto, Calif., by Chris, Gary, and Grant Zaiger and Leith Gardner. Hybrid of 46G731=(Laroda X Queen Ann) and plum of unknown origin. USPP 10385 issued 12 May 1998. Fruit: medium to large, $60 \mathrm{~mm}$ diameter, $57 \mathrm{~mm}$ long; nearly globose; skin red with light yellow to yellow ground color; flesh pale yellow to light yellow, firm; freestone when fully mature; matures 5 days earlier than Casselman, about the first week of August in California. Tree: large, vigorous, upright, productive.

Matinee.-An early-season, red-skinned Japanese plum. Origin: in Fresno, Calif., by Eric Wuhl. Open-pollinated seedling of Showtime. USPP 9836 issued 25 Mar. 1997. Fruit: medium, 55 mm diameter, 56 mm long; cordate; skin red to purple; flesh yellow with red just under skin, firm; cling; matures 2 weeks before Santa Rosa, first to second week of June in California. Tree: medium, medium vigor, upright, productive, semi-self fruitful, pollen golden.

Murietta.-An early-season, dark-skinned Japanese plum. Origin: in Modesto, by Chris, Gary, and Grant Zaiger and Leith Gardner. Open-pollinated seedling of Friar. USPP 9568 issued 4 June 1996. Fruit: medium to large, $63 \mathrm{~mm}$ diameter, $54 \mathrm{~mm}$ long; nearly globose, slightly flattened at stem end; skin dark red to blackish-blue; flesh pale yellow to yellow, firm; cling; matures first to second week of June in Central San Joanquin Valley, Calif. Tree: large, vigorous, upright, productive.

Primetime.-A midseason purple-skinned Japanese plum. Origin: in Fresno, Calif., by Eric Wuhl. Supposed hybrid of Challenger and Showtime. USPP 9022 issued 29 Dec. 1993. Fruit: large, 64 to 67 $\mathrm{mm}$ diameter, $67 \mathrm{~mm}$ long; cordate; skin red to deep purple-red; flesh light yellow-red, firm, crisp; cling; matures first week of July in Fresno, Calif. Tree: medium vigor, upright, very productive; partially selffruitful.

September King.-A very late-season, red-skinned Japanese plum. Origin: near Reedley, Calif., by Thomas Chamberlin, Sr. Chance seedling of unknown parentage. USPP 9513 issued 23 Apr. 1996. Fruit: Large, 62 to $70 \mathrm{~mm}$ diameter; round; skin dark red to bright red; flesh yellow with red next to skin, crisp; freestone; matures third week of September in central San Joaquin Valley of California. Tree: vigorous, upright, very productive; partially self-fruitful.

Teak Gold.-A very late-season, dark-skinned Japanese plum. Origin: near Capel River, Western Australia, by R.A. Yates. Chance seedling of unknown parentage. USPP 10277 issued 10 Mar. 1998. Fruit: large, $64 \mathrm{~mm}$ diameter, $67 \mathrm{~mm}$ long; conical, slightly elongated; skin burgundy-red with yellow under color; flesh light yellow, firm, crisp, low acid, sweet; semi-freestone; matures last week of August to first week of September in Washington state. Tree: medium vigor and size, upright, very productive; partially self-fruitful.

\section{PLUMCOT}

\section{D.W. Ramming \\ USDA Horticultural Crops Research Laboratory Fresno, Calif.}

Flavor King.-A late-ripening plumcot. Origin: in Modesto, Calif., by Chris, Gary, and Grant Zaiger and Leith Gardner. Hybrid of $29 \mathrm{~EB} 30=($ Mariposa $\times$ plumcot $=$ Red Beaut OP $) \times 42$ GA580 $=($ plumcot $=$ Red Beaut OP). USPP 8026 issued 10 Nov. 1992. Fruit: Med., 60 mm diameter; globose; skin yellow with red over-color, glabrous; flesh pale yellow to pale orange, firm, semi-clingstone; matures first week of August in California. Tree: medium to large, semi-upright, productive; self-unfruitful, pollen scant.

Flavorglo.-An early-ripening yellow plumcot. Origin: in Modesto, Calif., by Chris, Gary, and Grant Zaiger and Leith Gardner. Open-pollinated seedling of 35EA376=(Red Beaut OP). USPP 8922 issued 4 Oct. 1994. Fruit: large, $66 \mathrm{~mm}$ diameter and long; globose to slightly elongated; skin yellow, short pubescence; flesh cream to golden-yellow, firm, cling; matures fourth week of May in California. Tree: large, vigorous, semi-upright, moderate production; pollen white, present.

Flavorosa.-An early-ripening, dark-skinned plumcot. Origin: in Modesto, Calif., by Chris, Gary, and Grant Zaiger and Leith Gardner. Hybrid of 65EC664=(Royal Zee OP) and 42GA580 plumcot $=$ (irradiated Red Beaut OP). USPP 10285 issued 17 Mar. 1998. Fruit: Medium to large, $63 \mathrm{~mm}$ diameter, $51 \mathrm{~mm}$ long; oblate; skin blackishviolet, glabrous; flesh dark ruby-red, firm, $16^{\circ}$ Brix, cling; matures last 
week of May in California. Tree: large, vigorous, upright, productive; pollen white, present.

Geo Pride.-An early yellow plumcot. Origin: in Modesto, Calif., by Chris, Gary, and Grant Zaiger and Leith Gardner. Hybrid of 29EB30= (Mariposa $x$ plumcot from Red Beaut OP) and 42GA580=(plumcot from irradiated Red Beaut OP). USPP 10386 issued 12 May 1998. Fruit: medium, $54 \mathrm{~mm}$ diameter and $51 \mathrm{~mm}$ long; nearly globose; skin light yellow to yellow ground color overspread with garnet-red, glabrous; flesh light yellow to yellow, light red under skin, firm, $18^{\circ}$ Brix, freestone; matures second week of July in California. Tree: large, vigorous, semi-upright, productive; pollen white, present.

\section{RASPBERRY}

\section{Hugh Daubeny Pacific Agriculture Research Centre Agassiz, B.C., Canada}

Anne.-A yellow primocane-fruiting raspberry. Origin: Rutgers Fruit Research and Extension Centre, Cream Ridge, N.J., by J.A. Fiola. Amity x Glen Garry; tested as JEF-B1; introd. in 1999. Fruit: large size; yellow; firm; good flavor; relatively susceptible to Botrytis; limited shelf life; ripens as much as 10 days earlier than Heritage. Plant: yield similar to or slightly less than Heritage; relatively low number of vigorous primocanes. May have some root rot resistance.

Ariadne.-An early-ripening, primocane-fruiting raspberry. Origin: Kristianstad, Sweden, by B. Sjostedt. Selection BRu 8302-4 op; introd. in 1996. Fruit: moderate size; dark red; firm; conic; easy to harvest; sub-acid flavor; more resistant to Botrytis than Autumn Bliss; in Sweden ripens 2 weeks earlier than Autumn Bliss. Plant: high yield; numerous, erect, moderately spiny primocanes; spines are red and occur on upper half of canes.

Boheme.-An early-ripening, primocane-fruiting raspberry. Origin: Kristianstad, Sweden, by B. Sjostedt. Selection Ru 1-61 op; introd. in 1996. Fruit: small to moderate size; red; round to conic; easy to harvest; sub-acid flavor; more resistant to Botrytis than Autumn Bliss; in Sweden ripens 1 week earlier than Autumn Bliss. Plant: very high yield; very numerous, erect, nearly spineless primocanes.

Carmen.-An early-ripening, primocane-fruiting raspberry. Origin: Kristianstad, Sweden, by B. Sjostedt. Autumn Bliss op; introd. in 1996. Fruit: moderate to large size; red; firm; conic; easy to harvest; sub-acid flavor; more resistant to Botrytis than Autumn Bliss; in Sweden ripens 1 week earlier than Autumn Bliss. Plant: high yield; very numerous, spineless, red-colored canes.

Caroline.-A highly flavored, primocane-fruiting raspberry ripening earlier than Heritage. Origin: Rutgers Fruit Research and Extension Centre, Cream Ridge, N.J., by J.A. Fiola. Geo-1 (Autumn Bliss x Glen Moy) x Heritage; tested as JCR F1; introd. in 1999. Fruit: large size; red; firm; good flavor; long harvest season and as much as 2 weeks earlier ripening than Heritage; responds to warmer temperatures with earlier ripening. Plant: yield as much as or higher than Heritage; vigorous growth habit with moderately high numbers of primocanes. More tolerant to root rot and yellow rust than Heritage.

Encore.-A firm-fruited raspberry with wide adaptation and ripens significantly late to extend the harvest season. Origin: Cornell Univ. at New York State Agr. Expt. Sta., Geneva, by K.E. Maloney, J.E. Reich, and J.C. Sanford. Canby x Cherokee; cross made in 1976; selected in 1980; introd. in 1998. Propagated under nonexclusive licensing arrangement with Cornell Research Foundation; USPPAF. Fruit: medium size maintained throughout season; attractive red; firm; pleasant, mild, well-balanced flavor; easy to harvest; dry to touch; late with high percentage of fruit ripening from late July to early August. Plant: high yield; above average cane production; sturdy almost spineless self-supporting canes that can be trellised to improve harvest efficiency; winter hardy. Less susceptible to Phytophthoraincited root rot than Titan.

Jatsi.-A raspberry with good flavor suited for fresh market. Origin: Agricultural Research Centre for Finland, Mikkeli, by P. Dalman, H. Hiirsalmi, T. Hieturanta, and M. Linna. Ottawa X (Malling Promise x Merva); cross made in 1973; tested as 73130021; introd. in 1997. Fruit: medium size; somewhat glossy medium red; conic; firm; fairly difficult to harvest; good flavor; later ripening than standards
Muskoka and Heisa but earlier than Ville. Plant: relatively high yield; thick, sturdy canes with relatively few spines; moderately winter hardy. Susceptible to powdery mildew; has remained free of raspberry bushy dwarf virus.

Jenkka.-A winter-hardy raspberry that produces consistent yields. Origin: Agricultural Research Centre for Finland, Mikkeli, by P. Dalman, H. Hiirsalmi, T. Hieturanta, and M. Linna. (Malling Promise x Merva) x Ottawa; cross made in 1973; tested as 73120020; introd. in 1997. Fruit: medium size; glossy, medium red; relatively firm, round; fairly good flavor; later ripening than standards, Muskoka and Heisa, but earlier than Ville. Plant: consistent yield; numerous thin, flexible canes with some spines; winter hardy. Susceptible to powdery mildew; has remained free of raspberry bushy dwarf virus.

Kitsilano.-A very late-ripening raspberry suited to fresh-market use. Origin: Pacific Agriculture Research Centre, Agassiz, B.C., Canada, by H.A. Daubeny and C. Kempler. Comox x East Malling 3909/4, a fourth backcross derivative of Rubus crataegifolius; cross made in 1985; selected in 1988; tested as BC 85-18-16; introd. in 1998. Fruit: medium size; glossy medium red; relatively small drupelet; very firm; easy to harvest; good flavor; some resistance to both preand postharvest Botrytis-incited rots; extended season, ripening later than Tulameen with an overlap in some years with early primocanefruiting varieties. Plant: high yield; moderate numbers of canes; spines general but not objectionable; winter hardiness similar to Meeker and less than Chilliwack. Relatively susceptible to spur blight (Didymella applanata) and cane Botrytis; susceptible to Phytophthora fragariae var. rubi in greenhouse screening test; susceptible to natural infection by raspberry bushy dwarf virus, but rate of infection appears to be slow; resistant to the common strain of the North American aphid vector (Amphorophora agathonica) of the raspberry mosaic virus complex.

Lauren.-A large-fruited, early-ripening raspberry. Origin: Rutgers Fruit Research and Extension Centre, Cream Ridge, N.J., by J.A. Fiola. Titan x Reveille; tested as CDH-1; introd. in 1999. Fruit: very large size; red; firm with uneven collar; moderately good flavor; early ripening. Plant: good yield; very vigorous canes; low chilling requirement; canes susceptible to die-back in sites with fluctuating winter temperatures; excellent low-temperature hardiness. Somewhat less susceptible to root rot than Titan.

Lewis.-A high-quality, large-fruited, fresh-market raspberry for the Pacific Northwest and New Zealand. Origin: Corvallis, Ore., by C. Finn and F.J. Lawrence, USDA-ARS, Hort. and Food Res. Inst. of New Zealand, Oregon State Univ. and Washington State Univ. ORUS 1570 (Creston x ORUS 1094) x ORUS 1748 (Glen Isla x Willamette); cross made in 1975; selected in 1978; tested as ORUS 576-47; introd. in 1997. Fruit: medium-large; glossy medium red; very firm; easy to harvest by hand or by machine; excellent flavor; similar to Meeker for $\mathrm{pH}$, titratable acidity, and anthocyanin levels and greater for soluble solids; ripens 2-5 days later than Meeker. Plant: high yield; moderate number of canes with medium vigor and thickness and few spines; winter hardiness similar to Meeker. In New Zealand, susceptible to rust (Phragmidium rubi-idaei), root rot (Phytophthora cactorum), and bud moth (Herterocrossa rubophaga). In Oregon and Washington, no particular disease problems and, while not extremely sensitive to root rot (Phytophthora fragariae var. rubi), will show symptoms on heavy or wet soils.

Nawojka.-A raspberry producing uniform, good-flavored fruit suited to fresh market. Origin: Research Inst. of Pomology and Floriculture, Expt. Sta., Brzezna, Poland, by J. Danek; selection 80261 (EM 3655/46 op) x selection 80403 (SCRI 78/53/A5 op); cross made in 1985; tested as selection 85284; introd. in 1998. Fruit: medium to large size; light to medium red; uniform appearance; nearly round; excellent flavor; mid- to late-season ripening. Plant: moderate numbers of canes with moderate to high vigor; numerous small spines; medium to long, strong laterals. Relatively resistant to cane Botrytis and to spur blight (Didymella applanata); susceptible to natural infection by raspberry bushy dwarf virus.

Poranno Rose.-A yellow-fruited, primocane-fruiting raspberry for home gardens. Origin: Research Inst. of Pomology and Floriculture, Expt. Sta., Brezezna, Poland, by J. Danek; EM open-pollinated 4253/2, which has Rubus coreanus in its derivation; tested as selection 
80182; introd. in 1998. Fruit: medium to large size; yellow; round; firm; good flavor; some resistance to rot; ripening season similar to Heritage. Plant: strong, erect, spiny primocanes; fruits near top of cane and on short laterals on lower part. Resistant to cane diseases.

Prelude.-A very early-ripening floricane raspberry that produces a substantial crop on primocanes. Origin: Cornell Univ. at New York State Agr. Expt. Sta., Geneva, by K.E. Maloney, J.E. Reich, and J.C. Sanford. NY 817 [Hilton X NY 600 (Durham X September)] X Hilton; cross made in 1971; tested as NY 1009; introd. in 1998. Propagated under nonexclusive licensing arrangement with Cornell Research Foundation; USPPAF. Fruit: medium size; red; firm; round; uniform; mild and pleasant flavor; easy to harvest; floricane production extremely early; primocane production season similar to Heritage. Plant: combined summer and fall yields above average; vigorous, numerous canes; spines sparse; winter hardy.

Terri-Louise.-A primocane-fruiting raspberry with exceptionally large fruit size. Origin: Kent, U.K., by D.L. Jennings, Medway Fruits. Plant Breeder's Rights held by Meiosis Ltd. Glen Moy X Autumn Bliss; introd. in 1997. Fruit: very large; attractive red that darkens when overripe; firm flesh texture with weak skin strength; excellent flavor; in southern England starts to ripen in August and under plastic tunnels will crop until mid-December; produces very early spring crop on over-wintered canes. Plant: susceptible to raspberry bushy dwarf virus.

\section{SAPODILLA}

Robert J. Knight, Jr.

Univ. of Florida, Tropical Research and Education Center Homestead

Alano.-Compact plant that makes for size control and good fruit production. Origin: Thailand, introd. to Fla. from Hawaii in 1987. Fruit: medium large, 114-250 g, averaging $146 \mathrm{~g}, 63 \mathrm{~mm}$ long by 62 mm wide, of excellent quality, with 4.9 seeds on average; heavy bearer with smooth skin, latex in seed cavity; season fall, winter, spring. Tree: compact, easily trained to horizontal growth habit.

Betawi.-High-quality, large-fruited sapodilla. Origin: Yucatan, Mexico. Fruit: $140-315 \mathrm{~g}$, averaging $218 \mathrm{~g}, 90 \mathrm{~mm}$ long by $71 \mathrm{~mm}$ wide, of excellent quality with few seeds (average 2.8). Regular, heavy bearer; season fall, winter. Tree: upright, difficult to train, prone to severe limb breakage.

Hasyá.-Large-fruited variety. Origin: Oxkutzcab, Yucatan, Mexico. Fruit: 150-365 g, averaging 293 g, $96 \mathrm{~mm}$ long by $70 \mathrm{~mm}$ wide, of excellent quality with red highlights, an average of two seeds, a moderate bearer; fruit with a pleasant aroma, not too sweet; season winter, spring. Tree: upright, difficult to train, of poor growth habit.

Makok.-Small but attractive fruit variety. Origin: Thailand. Fruit: small, 30-140 g, averaging $63 \mathrm{~g}, 57 \mathrm{~mm}$ long by $42 \mathrm{~mm}$ wide, of good quality with an average of 2.1 seeds, a heavy bearer, needs thinning; smooth, pretty with greenish flesh; season spring, summer, fall. Tree: dwarf growth habit, easily trained.

Molix.-High-quality fruit but hard to train. Origin: Oxkutzcab, Yucatan, Mexico. Fruit: large, 150-360 g, averaging 295 g, 94 mm long by $72 \mathrm{~mm}$ wide, few seeds (average 1.8), of excellent quality with red highlights, a heavy bearer; season winter, spring. Tree: upright, difficult to train

Morena.-Large-fruited variety. Origin: Oxkutzcab, Yucatan, Mexico. Fruit: $170-345 \mathrm{~g}$, averaging $263 \mathrm{~g}, 98 \mathrm{~mm}$ long by $63 \mathrm{~mm}$ wide, few seeds (average two), of excellent quality with red highlights, moderate to heavy bearer; winter, spring. Tree: upright habit, not easily trained.

\section{STRAWBERRY}

\section{Chad E. Finn \\ USDA-ARS, Northwest Center for Small Fruit Research Corvallis, Ore.}

Adina.-A moderately productive, short-day cultivar that produces large attractive fruit continuously throughout the fruiting season. Origin: in Knoxfield by B.J. Morrison, Inst. of Hort. Development, Victoria. 88-042-35 x Parker; cross made in 1989; tested as 89-
064-2; introd. in 1997. Plant Breeder's Rights held. Licenced to Agriculture Victoria Services Pty. Ltd. Fruit: bright red; moderately glossy; seeds level with surface of the fruit; very large; highly attractive; primary fruit are wedge-shaped with conical secondary and tertiary fruit; flesh is light red with white core; firmer than Pajaro. Plant: short-day; semi-spreading, open plant with medium vigor; large, dark green, and moderately glossy leaves. Moderately productive with a long season. Primarily of interest due to its large attractive fruit and the maintenance of size throughout the fruiting season. Widely adapted in Australia.

Aires.-A day-neutral, fresh-market cultivar with conical fruit borne beneath the foliage. Origin: in Tudela, Spain, by J.M.A. Lopez, Plantas de Navarra, S.A., Navarra, Spain. 86-037 x 86-096; tested as 90-79-060; introd. in 1996. USPP 9757. Fruit: medium size; wedge to conical; brighter red than Selva; light internal color; very firm, but not as firm as Selva; more acid flavor than Selva; calyx difficult to remove. Plant: day-neutral, similar to Selva, less strongly day neutral than Irvine; benefits from chilling; medium vigor and density; higher yields than Selva.

Alinta.-A day-neutral, fresh-market cultivar whose outstanding characteristic is its production of highly attractive fruit throughout the fruiting season. Origin: in Knoxfield by B.J. Morrison, Inst. of Hort. Development, Victoria. 88-011-30 x Chandler; cross made in 1991; tested as 91-012-39; introd. in 1998. Plant Breeder's Rights held. Fruit: large; orange-red; very glossy; primaries are short wedgeshaped tending to conical on secondaries; broad band without achenes; flesh is light red throughout; similar to Selva in firmness; calyx is sharply reflexed and detaches easily. Plant: day-neutral; semi-spreading; medium dense; vigorous; leaves are dark green and moderately glossy; highly productive with very large early yield; will continue flowering during hot weather, although very hot weather may reduce fertility. Performs well from either summer or winter planting. Outstanding early productivity does not appear to benefit from additional chilling.

Arena.-A high-yielding, short-day, fresh-market cultivar with cylindrically shaped fruit. Origin: in Tudela, Spain, by J.M.A. Lopez, Plantas de Navarra, S.A., Navarra, Spain. 85-20 x 86-175; tested as 9032-013; introd. in 1996. USPP 9770. Fruit: large; conical to cylindrical; small calyx; glossy red exterior; light colored interior; difficult to remove calyx. Plant: short-day; needs chilling, such as occurs at a high elevation nursery or with cold storage for flower induction; medium vigor, density, and runner production. Adapted to tunnel production in Spain.

Aromas.-A high-yielding, day-neutral cultivar adapted to winter planting in Mediterranean environments similar to the central coast of California. Origin: at Univ. of California, Wolfskill Experimental Orchard, near Winters, Calif., by D.V. Shaw. Cal. 87.112-6 x Cal. 88.270-1; cross made in 1991; selected in 1992; tested as Cal 91.2483 in 1993 and later as CN209. USPP 10451. Fruit: larger and firmer than Seascape, larger fruit than Selva; fruit shape is short conic; percent cull fruit lower than Selva or Seascape; external and internal color darker than Selva and slightly darker than Seascape but very glossy; achenes red to dark red, even with the fruit or slightly indented; very good flavor, acidic similar to Seascape; fresh-market, processing, and home-garden uses. Plant: day-neutral type producing fruit over an extended period in arid, subtropical climate; production pattern later to initiate fruiting than Selva or Seascape, but produces more lateseason fruit; higher yielding than Selva or Seascape; plant with a relatively erect growth habit. Moderately susceptible to common leaf spot, and verticillium wilt; resistant to Phytophthora cactorum and anthracnose crown rot; resistant to powdery mildew; good tolerance to twospotted mite (substantially better than Selva or Seascape); tolerant to viruses occurring in California.

Burlington.-A weak, day-neutral cultivar with sustained production of large fruit from June to October in the Pacific Northwest. Origin: in Burlington, Wash., by C. Schwartze and A. Sakuma of Sakuma Bros. Farms. Tufts x EB 18 (USDA-ARS, Beltsville, Md.); cross made in 1978; selected in 1979; tested as SS 534; patented in 1986. USPP 5674. Fruit: large size but smaller than Selva; long conic; less uniform than Selva; glossy, light to medium orange-red; seeds yellow; interior flesh light orange-red; firm but not chewy; good 
flavor, consistently rated better than Quinault. Plants: weakly dayneutral; very large and vigorous plants; freely produces runners; more productive than Quinault. More tolerant of virus and powdery mildew than Quinault.

Cabot.-A midseason, exceptionally large-fruited, red stele-resistant strawberry adapted to northeastern North America. Origin: in Kentville, Nova Scotia, Canada, by A.R. Jamieson and N.L. Nickerson of the Atlantic Food and Horticulture Research Centre of Agriculture and Agri-Food Canada. (Elsanta x K79-5) x (ArKing x K79-4); cross made in 1990; selected in 1992; tested as K92-17 and introd. in 1998. Canadian Plant Breeder's Rights (\#0462). Fruit: first fruit are very large with a seasonal average of $25 \mathrm{~g}$; firm; bright red; with a good flavor. Plant: large; somewhat shy runnering; producing high yields from matted rows. Resistant to Phytophthora fragariae; moderately resistant to powdery mildew; susceptible to botrytis fruit rot.

Cacanska krupna.--An early-midseason, short-day, high-quality, and productive cultivar. Origin: in Belgrade, Serbia, by A.S. Stancevic and P.D. Misic of Cacak (Agr. Res. Inst.-Serbia). Surprise des Halles x Cacak 45/7; cross made in 1968; tested as III/18. Fruit: early but later than Cacanska rana; large (>15 g); intense red; bluntconic; aromatic; firm; can be shipped. Plant: short-day; moderate vigor; numerous runners; long, stiff peduncles hold fruit off the ground. Adapted to diverse growing conditions. Fairly resistant to Mycosphaerella fragariae. Excellent fresh market and good for processing.

Cacanska rana.-An early, short-day, high-quality, and productive cultivar. Origin: in Belgrade, Serbia, by A.S. Stancevic and P.D. Misic of Cacak (Agr. Res. Inst.-Serbia). Surprise des Halles x Cacak 45/7; cross made in 1968; tested as III/14. Fruit: medium size (12 g); very early; fire red; truncate-conical; very aromatic; firm; ships well. Plant: short-day; moderate vigor; produces many runner; productive. Very suitable for fresh and suitable for processing. Fairly resistant to Mycosphaerella fragariae and verticillium wilt.

Cartres.-A short-day, fresh-market cultivar with conical fruit. Origin: in Tudela, Spain, by J.M.A. Lopez, Plantas de Navarra, S.A., Navarra, Spain. 86-175 x 86-189; tested as 89-62-022; introd. in 1994. USPP 8622. Fruit: large and long; conical; uniform size and shape throughout the season with only a slight decrease in size; very firm; red exterior, medium-red interior color; glossy; low acidity and medium sweetness. Plant: short-day; medium vigor and density; medium number of runners.

Catalina.-An early-ripening, short-day, high-quality, fresh-market cultivar with tendency to be everbearing in more northern regions. Origin: at the New West Fruit Corp., Oxnard, Calif., by D. Small and J. Bagdasarian. A41 x Seascape; cross made in 1991; selected in 1993; tested as 19B50 and later B10; patented in 1995. USPP 9320. Fruit: typically wedge-shaped, some medium to long conic and while usually smooth, primaries are occasionally creased or cockscombed; size very good throughout the season; firm; darker red exterior than Chandler; lighter colored flesh; glossy; flavor comparable to other commercial California cultivars; Plant: short-day with tendency toward everbearing in more northern regions; very productive; more vigorous than Chandler, Camarosa, or Selva; canopy remains open throughout the season. Mild susceptibility to powdery mildew and angular leaf spot. Tolerant of verticillium wilt and Phytophthora spp. Shows good vigor under nonfumigated conditions.

Coronado.-A partially everbearing, high-quality, fresh-market cultivar that is earlier ripening and higher yielding than Balboa. Origin: in Oxnard, Calif. by T.M. Sjulin and A.Q. Amorao, Driscoll Strawberry Associates, Watsonville, Calif.; unidentified parentage; selected in 1991; patented in 1998. USPP 10221. Fruit: large; conical to wedge; red to dark red skin with medium glossiness; weak to medium calyx adherence; medium firmness; internal color light red and white; medium sweetness and acidity; very early-ripening. Plant: partially everbearing, will continue to reflower and fruit under cool conditions such as those that occur in coastal California; medium vigor; medium density. Susceptible to Xanthomonas fragariae, verticillium wilt, the anthracnose diseases caused by Colletotrichum acutatum, twospotted spider mites (Tetranychus urticae), cyclamen mites (Phytonemus pallidus) and lygus bugs (Lygus hesperus). Moderately resistant to powdery mildew and aphid-borne virus diseases.
Fruit moderately susceptible to decay by Botrytis cinerea and Rhizopus spp.

Darsanga.-A fresh-market, short-day strawberry with intense dark red internal and external color. Origin: in France by R.C. Hureau, Society Civile Darbonne. Tufts x Korona; introd. in 1998. USPP 10634. Fruit: medium size; uniform size and shape; conic; dark red internal and external color; calyx removal difficult; medium glossiness; very firm; less sensitive to bruising than Senga Sengana; more pleasant aroma fresh and lower drip loss than Senga Sengana; concentrated ripening. Plant: short-day type; vigorous; abundant runners; less dense than Senga Sengana; upright habit. Good general tolerance to pathogens observed in the field.

Darselect.-A fresh-market, short-day strawberry that is similar to Elsanta but is more erect, has longer petioles, larger fruit, and more uniform skin color. Origin: in France by R.C. Hureau, Society Civile Darbonne. Elsanta X Parker; introd. in 1998. USPP 10402. Fruit: large; conical; red, glossy and bright exterior; white interior; tough skin, juicy with good flavor; firm; large calyx. Plant: short-day type; very vigorous; large plant; lower chilling requirement than Elsanta; abundant runners. Tolerant of Phytophthora cactorum. Good winter or frost resistance; has tolerated $-25^{\circ} \mathrm{C}$.

Diamante.-A very large-fruited, day-neutral cultivar adapted to summer or winter planting in Mediterranean environments similar to the central coast of California. Origin: at Univ. of California, Wolfskill Experimental Orchard, near Winters, Calif., by D.V. Shaw. Cal. 87.112-6 x Cal. 88.270-1; cross made in 1991; selected in 1992; tested as Cal 91.248-6 in 1993 and later as CN210. USPP 10435. Fruit: much larger than Seascape and Selva, firmer than Seascape; fruit shape is a long rounded conic; percent cull fruit substantially lower than Selva or Seascape; external and internal color lighter than Selva and Seascape and very glossy; achenes yellow to red, even with the fruit or slightly indented; excellent flavor; fresh-market, processing, and home garden uses. Plant: day-neutral type producing fruit over an extended period in arid, subtropical climate; production pattern similar to Selva but less cyclic, produces more late-season fruit and is higher yielding than Selva or Seascape; compact plant with a relatively erect growth habit. Moderately susceptible to common leaf spot, verticillium wilt, Phytophthora cactorum and anthracnose crown rot; resistant to powdery mildew; good tolerance to twospotted mite (substantially better than Selva or Seascape); tolerant to viruses occurring in California.

Euroka.-A day-neutral cultivar with large, attractive, high-quality fruit that are particularly remarkable late in the season. Origin: in Knoxfield by B.J. Morrison, Inst. of Hort. Development, Victoria. Selva $\times$ 88-015; cross made in 1990; tested as 90-035-17. introd. in 1998. Plant Breeder's Rights held. Licenced to Agriculture Victoria Services Pty. Ltd. Fruit: highly attractive; uniformly red; large; very glossy; attractiveness improves as the season progresses; primary fruit wedge-shaped with secondaries and tertiary fruit conical; flesh light red throughout; firmness between Pajaro and Selva; calyx spreading and similar in size to the fruit. Plant: day-neutral; globose-shaped, medium-dense plant; vigorous; leaves medium-green and moderately glossy; highly productive provided the chilling requirement is satisfied. Flowers late, 2-3 weeks after Pajaro. Performs best when winter planted. Fills niche for high-quality late season cultivar. Tolerant of twospotted mite.

Firecracker.-A very late-ripening, virus-tolerant, fresh-market and processing strawberry adapted to the Pacific Northwest. Origin: in Corvallis, Ore., by C. Finn, F.J. Lawrence, and B.C. Strik; released jointly by USDA-ARS, Oregon State Univ., Washington State Univ. and Univ. of Idaho. ORUS 850-48 (Linn x ORUS 3727) x Totem; cross made in 1983; selected in 1985; tested as ORUS 1077-47; introd. in 1998. Fruit: similar size to Totem but overall more uniformly sized than Totem or Puget Reliance; uniform conic; very firm but not tough; bright uniform red external and internal color; lower drip loss and $\mathrm{pH}$ than Totem with similar or greater titratable acidity and soluble solid levels; tender skin; calyx easily removed; very late, 7 days later than Redcrest; flavor acidic and rated by a consumer panel to be similar to Totem; processing and fresh use in the late season. Plant: short-day type; yield similar to or higher than Totem; vigorous; not as tolerant of wet soils and root weevil-infested fields as Totem; resistant to foliar diseases, viruses and, due to late ripening, botrytis fruit rot in the 
Pacific Northwest.

G19.-A fresh-market strawberry adapted to Ontario as a replacement for Kent. Origin: at Horticultural Research Institute of Ontario, Univ. of Guelph in Simcoe, Ontario, Canada, by A. Dale, B.R. Hughes, and S. Wang. Chandler x Holiday; cross made in 1986 and selected by A. Dale in 1988; tested as 37G19. Introd. in 1998. Canadian Plant Breeder's Rights applied for. Fruit: similar in size to Kent; medium red with very firm flesh and a firm, moderately shiny skin; regular shape, but in some situations can be sightly irregular; ripening season similar to Kent. Plant: runners well and on a sandy soil has yields similar to Kent. Resistant to powdery mildew, slightly susceptible to the Simcoe strain of leaf scorch, which is a virulent form, and slightly susceptible to leaf spot. Susceptible to the fruit rot phase of anthracnose (Colletotrichum acutatum). Tolerant to moderate applications of terbacil.

Gaviota.-An everbearing cultivar with an extended season, adapted to summer or winter planting in Mediterranean environments similar to the central coast of California. Origin: at Univ. of California, Wolfskill Experimental Orchard, near Winters, Calif., by D.V. Shaw. Cal. 87.112-6 x Cal. 88.270-1; cross made in 1991; selected in 1992; tested as Cal 91.248-2 in 1993 and later as C205. USPP 10461. Fruit: larger and firmer than Chandler, larger but less firm than Camarosa; fruit shape is rounded conic; percent cull fruit lower than Chandler or Camarosa; external and internal color darker than Chandler and slightly darker than Camarosa; achenes yellow to dark red, even with the fruit or occasionally extruded; very good flavor, less aromatic than Chandler but with better balance and texture than Camarosa; fresh-market, processing, and home-garden uses. Plant: short-day-type producing fruit over an extended period in arid, subtropical climate, possibly a very weak everbearer, but does not flower in the nursery; production pattern later to initiate fruiting than Camarosa, but produces more late-season fruit; yield similar to Chandler but less than Camarosa; compact plant with a relatively erect growth habit. Moderately susceptible to common leaf spot, verticillium wilt and Phytophthora cactorum; resistant to powdery mildew and anthracnose crown rot; good tolerance to twospotted mite (better than Chandler and Camarosa); tolerant to viruses occurring in California.

Independence.-A very late-ripening, virus-tolerant, fresh-market strawberry adapted to the Pacific Northwest. Origin: in Corvallis, Ore., by C. Finn, F.J. Lawrence, and B.C. Strik; released jointly by USDA-ARS, Oregon State Univ., Washington State Univ. and Univ. of Idaho. ORUS 850-48 (Linn x ORUS 3727) x ORUS 750-1 (Totem x ORUS 3746); cross made in 1983; selected in 1985; tested as ORUS 1076-126; introd. in 1998. Fruit: average size is similar to Totem but primary fruit are larger; very firm but not tough; slight wedge and uneven; bright, uniform, red external color; very good internal color; tender skin; calyx not easily removed; very late, 7 days later than Redcrest; acidic but very pleasant flavor; fresh-market in the late season. Plant: short-day type; yield similar to or higher than Totem; vigorous; virus, winter, root weevil and wet soil tolerant in the Pacific Northwest; resistant to foliar diseases and, due to late ripening, botrytis fruit rot.

Joe Reiter.-A short-day, high-quality, fresh-market cultivar capable of producing a large spring crop when winter planted after a minimum amount of chilling. Origin: in Watsonville, Calif., by H.A. Johnson, Jr., Driscoll Strawberry Associates; G7 x G8; patented in 1984. USPP 5300. Fruit: consistent medium to large size; very attractive; conic to short, or medium wedge; high dessert quality; moderately firm skin; large calyx; very uniform fruit; excellent aroma; excellent flavor; long and thick pedicel. Plant: short-day type; very productive; vigorous; medium to large as a winter planted variety in southern California; runners freely and will become excessively large if given more than ideal chilling prior to planting.

Kalang.-A very productive, short-day plant with highly attractive firm, red fruit suitable for the fresh market, produced throughout the season. Origin: in Knoxfield by B.J. Morrison, Inst. of Hort. Development, Victoria. Pajaro x Parker; cross made in 1988; tested as 88-015-150; introd. in 1997. Plant Breeder's Rights held. Licenced to Agriculture Victoria Services Pty. Ltd. Fruit: large; bright red; moderately glossy; attractiveness maintained consistently throughout the season; predominantly conical with primary fruit slightly wedge shaped; medium red flesh throughout; marginally firmer than Pajaro; calyx is large, spreading and detaches easily. Plant: short-day; vigorous, medium dense plant; medium green, large leaves; upright growth habit; highly productive when summer planted. Suitable for a wide range of growing conditions in Australia. Dropped from propagation due to persistent white streak in the leaf.

Lacadie.-A high-quality, productive, short-day cultivar for freshmarket production in southcentral Canada and the Great Lakes region. Origin: at Agriculture and Agri-Food Canada, St Jean sur Richelieu, Quebec, by S. Khanizadeh, B. Theriault, O. Carrise, and D. Buszard. Guardian X Glooscap; cross made in 1989 by S. Khanizadeh and tested as SJ8916-50; introd. in 1998. U.S. and Canada Patent pending. Fruit: necked-conic; midseason; large; pale red; glossy; raised calyx; excellent productivity; very uniform; firm; good postharvest quality; decapped easily after harvest. Plant: June-bearing; yield similar to Joliette, Oka, Kent, Glooscap, and Chambly; semi-vigorous with 4-7 inflorescences per plant; tolerate temperatures below $-30{ }^{\circ} \mathrm{C}$; petioles are medium-long; dark green, flat, shiny, obovate leaflets with $\approx 17-24$ serrations; tolerant to the herbicide terbacil, resistant to powdery mildew, partially resistant to six North American eastern races of red stele, moderately resistant to leaf scorch, leaf blight, and leaf spot. Performs very well in sandy soil and well adapted to compact or heavy soil.

Lido.-A high-quality, fresh-market cultivar with outstanding postharvest quality and which is adapted to areas where Swede is currently grown. Origin: in Watsonville, Calif., by T.M. Sjulin, A.Q. Amorao, J.I. Espejo, Jr., and J.F. Coss, Driscoll Strawberry Associates; unidentified parentage; selected in 1991; patented in 1998. USPP 10534. Fruit: large; conical to cordate; uniform size throughout the season; firm; calyx adheres to fruit; medium to strong sweetness and weak to medium acidity; glossy, orange-red skin; orange-red flesh. Plant: short-day type but will continue to re-flower and fruit under cool conditions typified by coastal California; low vigor; medium to dense; produces few runners. Susceptible to Xanthomonas fragariae, verticillium wilt, and Colletotrichum acutatum. Moderately resistant to powdery mildew, aphid-borne virus diseases, and to fruit decay caused by Botrytis cinerea and Rhizopus sp. Plant is susceptible to injury by twospotted spider mite (Tetranychus urticae), cyclamen mite (Phytonemus pallidus), and lygus bug (Lygus hesperus).

Lowanna.-A day-neutral cultivar whose outstanding characteristic is its production of highly attractive fruit throughout the fruiting season, even in the early season. Origin: in Knoxfield by B.J. Morrison, Inst. of Hort. Development, Victoria. Selva x 89-064-1; cross made in 1992; tested as 92-021-433; introd. in 1998. Plant Breeder's Rights held. Fruit: extremely attractive; uniformly red; very glossy; attractiveness is maintained throughout the season; uniformly conic; well pollinated; flesh light red throughout; firmness similar to Selva; calyx spreading, similar in size to the fruit, and detach easily. Plant: dayneutral; forms globose-shaped plant; medium density; moderate vigor; leaves dark green, flat in cross section, smooth, and moderately glossy; highly productive. Consistent fruit shape and excellent pollination even early in the season will reduce grading costs and increase attractiveness of punnets.

Milsei.-A short-day, fresh-market cultivar with conical fruit. Origin: in Tudela, Spain, by J.M.A. Lopez, Plantas de Navarra, S.A., Navarra, Spain. Parker x Chandler; tested as 85-116-19; patented 1992. USPP 7864. Fruit: very large; conic to wedge; smooth, glossy and red exterior; interior orange-red; fruit juiciness, sweetness, and flavor are medium to strong; acidity higher than in Chandler; very good shipping characteristics; firm; calyx diameter similar to fruit and they are strongly held. Plant: short-day type; vigorous; productive.

Mr. P.-A day-neutral, fresh-market cultivar with good flavor, suitable to central coast region of California. Origin: in Watsonville, Calif., by H.A. Johnson, Jr. and A.Q. Amorao, Driscoll Strawberry Associates. B6.117 x D5.23; patented in 1986. USPP 5840. Fruit: large, larger than Heidi; medium wedge to conic; very good flavor; attractive; firm skin and flesh; rounded shoulder on fruit; glossy; red exterior; flesh light colored; calyx removes easily in warm weather or if inadequately irrigated. Plant: day-neutral type; produces many crowns; productive with peak in August if planted during late JanuaryMarch in the central coast region of California; medium to large size 
plant. More susceptible than Heidi to injury from thrips feeding causing a bronzing and lack of gloss. Will not reach maximum potential in saline soils. Virus tolerant.

Nama.-An early-ripening, short-day, fresh-market cultivar for fall production under polyethylene tunnels in Israel. Origin: in Bet Dagan, Israel, by S. Izhar and E. Izsak, Ministry of Agr., The Volcani Center. Chandler x 232; introd. in 1994. USPP 8747. Fruit: large; wedge-shaped primaries, conical secondaries; early maturing; orangered external color; internal color light red; calyx firmly attached; uniform size and shape throughout the season; medium firm; good taste; good shelf-life. Plant: short-day type; dense and vigorous; produces fruit from November until summer. An "infra short day variety," which are induced to initiate flower bud primordia in response to relatively long light regimes (but under short-day conditions) and are relatively insensitive to night temperatures. Adapted to production in plastic tunnels

Nonda.-A day-neutral, fresh-market cultivar with large, attractive fruit whose size and quality are maintained throughout the season. Origin: in Knoxfield by B.J. Morrison, Inst. of Hort. Development, Victoria. 88-011-30 x Parker; cross made in 1991; tested as 91-103-7; introd. in 1998. Plant Breeder's Rights held. Fruit: very large; orangered; very glossy; predominantly conical; flesh is medium-red throughout; similar firmness to Pajaro; calyx is small, spreading and detaches reasonably easily. Plant: day-neutral; moderately vigorous; medium dense; globose-shaped plant; dark green leaves; highly productive. Performs best when winter planted and will benefit from additional chilling. Resistant to twospotted mite.

Onebor.-A productive, fresh-market strawberry adapted to Mediterranean climates, glasshouses, and hydroponic production systems. Origin: by D. Musacchi and M. Leis with Consorzio Italiano Vivaisti Co. in Ferrara, Italy. Gorella X Selection No. 15; released 1994. USPP 8535. Fruit: large; primarily conic; bright red and glossy; pale red interior; calyx not easily removed; medium sweetness, acidity and aroma; hollow cores in primary fruit; fruit keep well. Plant: short-day type, however, requires $12-15 \mathrm{~h}$ per day to trigger shift from vegetative to reproductive phase; compact; very good production; produces more branched crowns than Gorella. Less sensitive to downy mildew and leaf spot than Gorella.

Pacific.-A strong day-neutral cultivar adapted to summer or winter planting in Mediterranean environments similar to the central coast of California. Origin: at Univ. of California, Wolfskill Experimental Orchard, near Winters, Calif., by D.V. Shaw. Seascape x Cal. 88.118-603; cross made in 1991; selected in 1992; tested as Cal 91.324-1 in 1993 and later as CN211. USPP 10436. Fruit: much larger than Seascape and Selva, firmer than Seascape; fruit shape is a short symmetric conic; percent cull fruit lower than Selva or Seascape; external and internal color darker than Selva and lighter than Seascape, very glossy fruit; achenes red to dark red, even with the fruit or slightly extruded; good flavor; fresh-market, processing, and home-garden uses. Plant: day-neutral type producing fruit over an extended period in arid, subtropical climate; production pattern similar to Selva, produces less late-season fruit but is higher yielding than Selva, higher yielding and similar late-season production to Seascape; compact plant with a growth habit similar to Seascape. Moderately susceptible to common leaf spot verticillium wilt, anthracnose crown rot and powdery mildew; moderate tolerance to twospotted mite (better than Selva or Seascape); tolerant to viruses occurring in California.

Rosa Linda.-A short-day strawberry recommended for west central Florida and other areas with mild winter climates because of its ability to produce high early-season (December-February) yields of attractive flavorful fruit. Origin: in Dover, Fla., by C.K. Chandler, Univ. of Florida's Gulf Coast Research and Education Center. FL 87418 x FL 87-200; tested as FL 90-15. USPP 9866. Fruit: primary fruit variable in shape; secondary and later are typically conic; bright red and darker than Sweet Charlie; internal color is mostly bright red but darker than in Sweet Charlie; moderately firm; size similar to Sweet Charlie; flavor comparable to Sweet Charlie but slightly less sweet with a hint of rose aroma. Plant: short-day; medium to large; upright; similar to Sweet Charlie in the production and timing of its runners; supplemental chilling not needed to perform well; flower buds initiate soon after being exposed to average daily temperatures of $21^{\circ} \mathrm{C}$ or lower in early fall; medium to high yield; greater early-season yield than Oso Grande but less than Sweet Charlie. More resistant to phomopsis leaf blight and fruit rot, angular (bacterial) leaf spot, and botrytis fruit rot than is Sweet Charlie, and more resistant to powdery mildew and twospotted spider mite than Selva. Moderately susceptible to anthracnose crown and fruit rot.

Ruby Red.-A late-ripening, short-day strawberry cultivar for the midwestern U.S. Origin: in Rockport, Ind., by A. Cook, patent assigned to H. Boll, Champaign, Ill. [([(Canall $x$ Twentieth Century) $x$ Twentieth Century] x Ogallala) $x$ Oberschlesien] x Surecrop; cross made in 1969; patented in 1984; USPP 5232. Fruit: very large; late ripening; medium red exterior with light medium red flesh; primary berries wedge to conic and secondary and later mostly conic; glossy; very firm; thick and long pedicels. Plant: short-day type; large plants; vigorous, few runners.

Sable.-An early-season, red stele-resistant strawberry adapted to northeastern North America. Origin: in Kentville, Nova Scotia, Canada, by A.R. Jamieson and N.L. Nickerson of the Atlantic Food and Horticulture Research Centre of Agriculture and Agri-Food Canada. Veestar X Cavendish; cross made in 1988; selected in 1990; tested as K90-1 and introd. in 1998. Canadian Plant Breeder's Rights (\#0461). Fruit: medium-sized, larger than Veestar, medium firm, attractive with a very good flavor, ripening with or just following Veestar. Recommended for pick-your-own operations where red stele resistance is required. Plant: vigorous, producing medium to high yields from matted rows. Contains complex resistance to Phytophthora fragariae and is moderately resistant to powdery mildew.

Sachinoka.-A fresh-market strawberry adapted to forcing culture in Japan with excellent fruit, storage, and shipping quality. Origin: in Kurume Branch of Natl. Res. Inst. Veg. Ornam. Plants and Tea, Japan, by T. Mochizuki, M. Morishita, Y. Noguchi, K. Sone, and O. Yamakawa. Toyonoka X Aiberry; cross made in 1987; selected in 1992 as Kurume No. 52; introd. in 1996. Japanese patent pending. Fruit: slightly smaller than Toyonoka but larger than Nyohou, the leading variety in forcing culture of eastern Japan; shiny, scarlet skin; uniform conic shape; firmness is $\approx 20 \%$ higher than Toyonoka and Nyohou, thus postharvest handling efficiency and shipping quality for long distance is better than Toyonoka; high sugar and ascorbic acid contents; suitable flesh texture for fresh consumption; not as aromatic as Toyonoka. Plant: short-day type; terminal flower bud is differentiated in mid-September under natural conditions in Kurume, a few days later than Toyonoka, the leading variety in forcing culture of western Japan; lateral fruit clusters are formed continuously and plants maintain their size even in midwinter under forcing condition; early yield in forcing culture is $50 \%$ to $80 \%$ of Toyonoka, while total yield until spring is similar. Susceptible to anthracnose, fusarium wilt and powdery mildew, but symptom severity and spread of powdery mildew is less than Toyonoka under forcing conditions. Adapted to forcing culture from southern Tohoku to Kyushu area, especially for large-scale growers who need labor-saving practices and excellent shipping quality in order to ship long distances to large markets.

San Miguel.-A fresh-market strawberry that is similar to Camarosa in geographic adaptation and season of ripening but which has less vigor and fewer branch crowns than Camarosa. Origin: in Watsonville, Calif., by A.Q. Amorao and T.M. Sjulin, Driscoll Strawberry Associates. Seascape X K6; selected in 1992; patented in 1998. USPP 10642. Fruit: large; conical to almost cylindrical; lighter red internal and external color than Camarosa; glossy; firm; unusually long pedicels; calyx not easily removed; medium to strong sweetness, acidity and texture; fruit ripen 2-3 weeks later than Camarosa. Plant: short-day type but will continue to re-flower and fruit under cool conditions typified by coastal California; medium density and vigor; requires slightly more chilling than Camarosa or Chandler but less than Seascape; higher yielding than Camarosa. Resistant to high $\mathrm{pH}$ and high soil salt levels. Moderately susceptible to Xanthomonas fragariae and twospotted mite. Susceptible to Tarsonemus pallidus, Aphis sp., and lygus bug. Moderately resistant to powdery mildew, Ramularia tulasnei, Phomopsis obscurans, strawberry mottle virus, and Zythia fragariae. Fruit is moderately susceptible to decay by botrytis fruit rot.

Shalom.-An extremely early-ripening strawberry adapted to culture under polyethylene tunnels in Israel. Origin: in Bet Dagan, 
Israel, by E. Izsak and S. Izhar, Ministry of Agr., The Volcani Center. Rachel x Douglas; introd. in 1991. USPP 7876. Fruit: early ripening; primary and secondary conical but some wedge-shaped; large; glossy red often with white shoulders; uneven color; light red internal color; calyx adheres strongly; medium sweetness; mild flavor. Plant: shortday type; plant habit similar to Senga Sengana; very vigorous and dense foliage; few runners produced. Adapted to winter production under polyethylene tunnels in Israel.

Talee.-A highly productive, short-day, fresh-market cultivar with excellent potential for early winter planting. Origin: in Knoxfield by B.J. Morrison, Inst. of Hort. Development, Victoria. Parker X Pajaro; cross made in 1990; tested as 90-008-793; introd. in 1997. Plant Breeder's Rights held. Licenced to Agriculture Victoria Services Pty. Ltd. Fruit: large; bright red; very glossy; attractiveness maintained throughout season. Predominantly conical with little variation on secondaries an tertiaries; flesh medium red throughout; firmer than Pajaro; calyx is small, sharply reflexed and detaches very easily. Plant: short-day; vigorous, medium dense plant; medium-green, large leaves; semi-spreading growth habit; highly productive when summer planted but may be planted in early winter provided excessive chill is avoided. Due to vigor, lower plant density and moderate nitrogen are suggested. Appears suitable for a wide range of growing conditions in Australia.

Tallara.-A productive, short-day, fresh-market strawberry that is suitable for a wide range of growing conditions in Australia . Origin: in Knoxfield by B.J. Morrison, Inst. of Hort. Development, Victoria. Parker X Pajaro; cross made in 1988; tested as 88-022-296; introd. in 1997. Plant Breeder's Rights held. Licensed to Agriculture Victoria Services Pty. Ltd. Fruit: large, orange-red, very glossy; attractiveness maintained throughout the season; uniform conic; medium red with lighter colored core; substantially firmer than Pajaro; calyx detaches easily. Plant: short-day type; vigorous, medium dense plant with an upright growth habit; very productive, even when planted in early winter. Fruit resist rain damage.

Virginia.-An early-ripening, short-day, fresh-market cultivar for fall production under polyethylene tunnels in Israel. Origin: in Bet Dagan, Israel, by S. Izhar and E. Izsak. Ministry of Agr., The Volcani Center. Chandler x 230; introd. in 1994. USPP 8748. Fruit: large; wedge-shaped; uniform size and shape throughout the season; medium firm; light red and bright external color; pale red internal color; calyx difficult to remove; good taste; good shelf-life. Plant: short-day type; dense and vigorous; produces fruit from November until summer. Adapted to production in plastic tunnels.

Yamaska.-A very late-ripening, short-day cultivar. Origin: at Agriculture and Agri-Food Canada, St. Jean sur Richelieu, Quebec, by S. Khanizadeh, B. Theriault, O. Carrise, and D. Buszard. Pandora X Bogota; cross made in 1989 by S. Khanizadeh and tested as SJ897001; introd. in 1998. Fruit: very late, 5 to 6 days after Bounty; excellent to extend the season; large; dark glossy red; very firm; uniform, oblate to globose and occasionally short-wedged; flowers are sometimes staminate similar to its parent Pandora. Plant: very vigorous; $2-5$ inflorescences per plant; tolerates temperatures below $-30^{\circ} \mathrm{C}$; petioles are long, with large, dark green, flat, shiny, obovate leaflets with 2228 serrations; yield is similar to most of the Quebec-grown cultivars but out yielded Sparkle. Moderately susceptible to the six North American Eastern races of red stele similar to Sparkle, semi-resistant to leaf scorch, leaf blight, and leaf spot. No sign of botrytis fruit rot was observed during the course of evaluation.

\section{INDEX OF VARIETIES DESCRIBED}

(synonyms in italics)

\author{
3-14-71 GRAPE \\ 552 GRAPE \\ 7-B PLUM \\ AC Harflame NECTARINE \\ AC Harrow Dawn PEACH \\ AC Harrow Fair PEACH \\ Adina STRAWBERRY
}

Aires STRAWBERRY

Alano SAPODILLA

Alinta STRAWBERRY

Alkmene APPLE

Allstar PEACH

Alphonso MANGO

Aman Dusehri MANGO

Amélie MANGO

Anderson Red Delicious APPLE

Anne RASPBERRY

Appus MANGO

Arctic Gold NECTARINE

Arena STRAWBERRY

Argaman GRAPE

Ariadne RASPBERRY

Arirang ASIAN PEAR

ArkCharm APPLE

Arkin CARAMBOLA

Aromas STRAWBERRY

Arumanis MANGO

ASAJU ASIAN PEAR

Asio 1 ASIAN PEAR

Asio 2 ASIAN PEAR

Asio 3 ASIAN PEAR

Asio 4 ASIAN PEAR

Aurora APPLE

Autumnprince PEACH

B-10 CARAMBOLA

Badami MANGO

Baigent APPLE

Bangalora MANGO

Beloruskaya Sladkaya CURRANT

Ben Alder CURRANT (Addendum)

Ben Connan CURRANT (Addendum)

Beni Shogun APPLE

Betawi SAPODILLA

Bhojpuri MANGO

Biehn EUROPEAN PEAR

Big Red Gala APPLE

Biloxi BLUEBERRY

Blazeprince PEACH

Blazingstar PEACH

Blue Gusto PLUM

Bluebyrd PLUM

Bluecrisp BLUEBERRY

Blushingstar PEACH

Boheme RASPBERRY

Bolero APPLE

Bombai MANGO

Bombay Green MANGO

Bombay Yellow MANGO

Bowen MANGO

BP-1 PEAR ROOTSTOCK (Addendum)

BP-3 PEAR ROOTSTOCK (Addendum)

Brighton 650 GRAPE

Brock APPLE

Brodtorp CURRANT

Bronze Beauty Bosc EUROPEAN PEAR

Brookfield Gala APPLE

Buckeye Gala APPLE

Burlington STRAWBERRY

Cabot STRAWBERRY

Cacak Thornless BLACKBERRY

Cacanska bestrna BLACKBERRY

Cacanska krupna STRAWBERRY

Cacanska rana STRAWBERRY

Caitlin APPLE

Carmen RASPBERRY

Caroline RASPBERRY

Cartres STRAWBERRY

Castleton PLUM (Addendum) 
Catalina STRAWBERRY

Charlotte APPLE

Chausa MANGO

Cinnamon EUROPEAN PEAR

Collector MANGO

Coralstar PEACH

Coronado STRAWBERRY

Cowley BLACKBERRY

Cox's Miracle Berry BLACKBERRY

Crimson Gala APPLE

Crimson Jonagold APPLE

Crunchyblue BLUEBERRY

Crystal Belle NECTARINE

Crystal Red NECTARINE

Dade WHITE SAPOTE (Addendum)

Danbae ASIAN PEAR

Darbhanga MANGO

Darsanga STRAWBERRY

Darselect STRAWBERRY

Dashehari MANGO

Dasheri MANGO

David Ford MANGO

Demak CARAMBOLA

Diamante STRAWBERRY

Doyle's BLACKBERRY

Duplin BLUEBERRY

Echota BLUEBERRY

Elliott APPLE

Emil BLUEBERRY

Emperatriz GRAPE

Encore RASPBERRY

Euroka STRAWBERRY

Everthornless BLACKBERRY

Ewais MANGO

Exel's Everbearing BLACKBERRY

Firecracker STRAWBERRY

Flamed Globe GRAPE

Flamenco APPLE

Flamin Fury P.F. 1 PEACH

Flamin Fury P.F. 12B PEACH

Flamin Fury P.F. 15A PEACH

Flamin Fury P.F. 17 PEACH

Flamin Fury P.F. 20-007 PEACH

Flamin Fury P.F. 23 PEACH

Flamin Fury P.F. 24-007 PEACH

Flamin Fury P.F. 25 PEACH

Flamin Fury P.F. 27A PEACH

Flamin Fury P.F. 5B PEACH

Flamin Fury P.F. 7 PEACH

Flavor King PLUMCOT

Flavorglo PLUMCOT

Flavorosa PLUMCOT

Friendship BLUEBERRY

Fuji-Spike APPLE

Fwang Tung CARAMBOLA

G19 STRAWBERRY

GalaSupreme APPLE (Addendum)

Gale Gala APPLE

Gaviota STRAWBERRY

Geo Pride PLUMCOT

Glenglo PEACH

Glowingstar PEACH

Gohabunder MANGO

Gold Nugget APPLE

Golda GOOSEBERRY

Golden Star CARAMBOLA (Addendum)

Golek MANGO

Golubka CURRANT

Grape MANGO

Gundu MANGO

Hadialaziz MANGO
Hajipur Langra MANGO

Haphus MANGO

Hardoi MANGO

Harflame NECTARINE

Harrow Dawn PEACH

Harrow Fair PEACH

Harrow Sweet EUROPEAN PEAR (Addendum)

Hartencourt APPLE

Harumanis MANGO

Hasyá SAPODILLA

Heinicke APPLE

Heisei Fuji APPLE

Helen BLACKBERRY

Hercules APPLE

Hew-1 CARAMBOLA

Hiralal Bombai MANGO

Hiromi Red PLUM

Improved Honeycot APRICOT

Independence STRAWBERRY

Ira BLUEBERRY

It Delicious APPLE

Jackson APPLE

Jatsi RASPBERRY

Jenkka RASPBERRY

Joanna Red PLUM

Joburn Braeburn APPLE

Joe Reiter STRAWBERRY

Jonathan TF-812 APPLE

Jonkheer van Tets CURRANT

Jubilee Fuji APPLE

Julie MANGO

July Pearl NECTARINE

Juneprincess NECTARINE

Junifer CURRANT

JunoSan ASIAN PEAR

Kagdi MANGO

Kalang STRAWBERRY

Kali Bombai MANGO

Kallamai MANGO

Kary CARAMBOLA (Addendum)

Kensington MANGO

Kensington Pride MANGO

Khader MANGO

Khader Pasand MANGO

Kharaji MANGO

Kiddle APPLE

Killi MANGO

Kitsilano RASPBERRY

Korean Giant ASIAN PEAR

Kvo Savoy MANGO

Lacadie STRAWBERRY

Laile Alipur MANGO

Langarhi MANGO

Langra Faquirwala MANGO

Langra MANGO

Late Honeycot APRICOT

Lauren RASPBERRY

Lewis RASPBERRY

Lido STRAWBERRY

Lochbuie Braeburn APPLE

Lorna APRICOT

Lowanna STRAWBERRY

Lucky Jon APPLE

Lucky Rose Golden APPLE

Lydia's Red Gala APPLE

Lynd-Spur APPLE

Mabrouka MANGO

Madoe MANGO

Madu MANGO

Makok SAPODILLA

Malaga APPLE 
Malda MANGO

Mallika MANGO

Manzanillo-Nunez MANGO

Matinee PLUM

May Duke GOOSEBERRY

Meader BLUEBERRY

Midnight Spur Delicious APPLE

Milsei STRAWBERRY

Minaj Smyriov CURRANT

Molix SAPODILLA

MonArk APPLE

Montgomery BLUEBERRY

Morena SAPODILLA

Mr. P STRAWBERRY

Mucurines GOOSEBERRY

Mukku MANGO

Murietta PLUM

Myra Red Fuji APPLE

Nadusalai MANGO

Nama STRAWBERRY

Naomi MANGO

Nawojka RASPBERRY

Neelum MANGO

Nonda STRAWBERRY

Nuwan Chun MANGO

Obelisk APPLE

Obrogala APPLE

Ojebyn CURRANT

Olsentwo APPLE

Olympic ASIAN PEAR

Ometa CURRANT

Onebor STRAWBERRY

Orkan BLACKBERRY

Pacific Gala APPLE

Pacific STRAWBERRY

Paheri MANGO

Pairi MANGO

Pairie MANGO

Peace Valley 1001 APPLE

Pender BLUEBERRY

Per Can BLACKBERRY

Peter MANGO

Peter Pasand MANGO

Pilot Alexandr Mamkin CURRANT

Pinova APPLE

Polka APPLE

Polyanna GRAPE

Poranno Rose RASPBERRY

Prelude RASPBERRY

Pretty Lady PEACH

Primetime PLUM

Putte BLUEBERRY

PV 1001 APPLE

Pyrodwarf PEAR ROOTSTOCK

Radiant Spur Delicious APPLE

Ralli Seedless GRAPE

Raspuri MANGO

Redchief Delicious APPLE

Redcort APPLE

Redlac CHERRY

Redmax APPLE

Redstar PEACH

Redwinter APPLE

Rhenus 1 PEAR ROOTSTOCK

Risingstar PEACH

Robada APRICOT

Rokula GOOSEBERRY

Rolan CURRANT

Rolonda GOOSEBERRY

Romagold APPLE

Rondom CURRANT
Rosa Linda STRAWBERRY

Rosa MANGO

Rosco GOOSEBERRY

Rosetta CURRANT

Rotet CURRANT

Rovada CURRANT

Royal Court APPLE

Royal Lady PEACH

Rubel BLUEBERRY

Ruby Jon APPLE

Ruby Red STRAWBERRY

Rubyprince PEACH

Sable STRAWBERRY

Sachinoka STRAWBERRY

Samar Bahisht Chausa MANGO

Sampson BLUEBERRY

San Miguel STRAWBERRY

Sandersha MANGO

Sandra Rose CHERRY

Santa Fe BLUEBERRY

Santina CHERRY

Sarauli MANGO

Scarlet Sun NECTARINE

Schlect Spur Delicious APPLE

September King PLUM

Shalom STRAWBERRY

Sheeri-Dhan MANGO

Simcoe CHERRY

Simmons APPLE

Siskiyou BLACKBERRY

Skeena CHERRY

Sommerfeld APPLE

Southern Pearl PEACH

Spring Gem PEACH

Springprince PEACH

St. Julienne MANGO

Starfire PEACH

Stark Crimson Spire APPLE

Stark Emerald Spire APPLE

Stark Encore NECTARINE

Stark Galaxy Gala APPLE

Stark GrandGala APPLE

Stark Irish Spire APPLE

Stark Ovation NECTARINE

Stark Saturn PEACH

Stark Scarlet Spire APPLE

Stark Ultra Spire APPLE

Stark UltraRed Gala APPLE

Starling APPLE

Stellar APPLE

Suaprieight APRICOT

Suapriseven APRICOT

Sugrathirteen GRAPE

Sumleta CHERRY

Sumleta Sonata CHERRY

Summer Breeze PEACH

Summer Serenade PEACH

Summit BLUEBERRY

Sumnue CHERRY

Sumnue Cristalina CHERRY

Sumpaca Celeste CHERRY

Sumpaca CHERRY

Sumste CHERRY

Sumste Samba CHERRY

Sun Fuji APPLE

SunCrisp APPLE (Addendum)

Sureprince PEACH

SuSan ASIAN PEAR

Sweetheart CHERRY

Sylhet MANGO

Symphony CHERRY 
T.A.C.-114 APPLE

Taimour MANGO

Talee STRAWBERRY

Tallara STRAWBERRY

Taylor's Gold Comice EUROPEAN PEAR

Teak Gold PLUM

Tehranivee CHERRY

Telamon APPLE

Tenah CURRANT

Terri-Louise RASPBERRY

Thevadimuthi MANGO

Tieton CHERRY

Tikari MANGO

Timp-Gold APPLE

Titania CURRANT

Totapuri MANGO

Trajan APPLE

Treco Red Fuji APPLE

Tropic Sweet APPLE

Tsema CURRANT

Tuscan APPLE

Twin Bee Gala APPLE

UF Gold PEACH

USPP 10010 GalaSupreme APPLE

USPP 10016 Brookfield Gala APPLE

USPP 10049 Royal Court APPLE

USPP 10114 Gale Gala APPLE

USPP 10115 Ruby Jon APPLE

USPP 10116 7-B PLUM

USPP 10165 Suapriseven APRICOT

USPP 10221 Coronado STRAWBERRY

USPP 10232 Suaprieight APRICOT

USPP 10277 Teak Gold PLUM

USPP 10285 Flavorosa PLUMCOT

USPP 10293 July Pearl NECTARINE

USPP 10325 Biehn EUROPEAN PEAR

USPP 10385 Joanna Red PLUM

USPP 10386 Geo Pride PLUMCOT

USPP 10402 Darselect STRAWBERRY

USPP 10434 Sugrathirteen GRAPE

USPP 10435 Diamante STRAWBERRY

USPP 10436 Pacific STRAWBERRY

USPP 10451 Aromas STRAWBERRY

USPP 10458 Big Red Gala APPLE

USPP 10461 Gaviota STRAWBERRY

USPP 10490 Flamin Fury P.F. 7 PEACH

USPP 10534 Lido STRAWBERRY

USPP 10545 Risingstar PEACH

USPP 10546 Redstar PEACH

USPP 10548 Starfire PEACH

USPP 10549 Allstar PEACH

USPP 10554 Blushingstar PEACH

USPP 10555 Blazingstar PEACH

USPP 10556 Glowingstar PEACH

USPP 10634 Darsanga STRAWBERRY

USPP 10642 San Miguel STRAWBERRY

USPP 10652 Glenglo PEACH

USPP 4094 Doyle's BLACKBERRY

USPP 5095 Redcort APPLE

USPP 5123 Stark Saturn PEACH

USPP 5232 Ruby Red STRAWBERRY

USPP 5300 Joe Reiter STRAWBERRY

USPP 5674 Burlington STRAWBERRY

USPP 5833 Emperatriz GRAPE

USPP 5840 Mr. P STRAWBERRY

USPP 6101 Exel's Everbearing BLACKBERRY

USPP 6105 Cox's Miracle Berry BLACKBERRY

USPP 6224 Stark Ultra Spire APPLE

USPP 6225 Stark Emerald Spire APPLE

USPP 6226 Stark Scarlet Spire APPLE

USPP 6458 Flamed Globe GRAPE
USPP 6955 Stark Galaxy Gala APPLE

USPP 7167 Redmax APPLE

USPP 7251 Per Can BLACKBERRY

USPP 7485 Wimmers Bosc EUROPEAN PEAR

USPP 7864 Milsei STRAWBERRY

USPP 7876 Shalom STRAWBERRY

USPP 7997 Beni Shogun APPLE

USPP 8026 Flavor King PLUMCOT

USPP 8164 Flamin Fury P.F. 23 PEACH

USPP 8169 Flamin Fury P.F. 17 PEACH

USPP 8211 Royal Lady PEACH

USPP 8234 Sommerfeld APPLE

USPP 8297 3-14-71 GRAPE

USPP 8308 Taylor's Gold Comice EUROPEAN PEAR

USPP 8499 Brighton 650 GRAPE

USPP 8535 Onebor STRAWBERRY

USPP 8622 Cartres STRAWBERRY

USPP 8673 Crimson Gala APPLE

USPP 8701 Lucky Jon APPLE

USPP 8721 Redlac CHERRY

USPP 8747 Nama STRAWBERRY

USPP 8748 Virginia STRAWBERRY

USPP 8922 Flavorglo PLUMCOT

USPP 8949 Stark Encore NECTARINE

USPP 8978 Flamin Fury P.F. 15A PEACH

USPP 9022 Primetime PLUM

USPP 9060 Stark Crimson Spire APPLE

USPP 9061 Stark Irish Spire APPLE

USPP 9099 Crystal Red NECTARINE

USPP 9129 Flamin Fury P.F. 1 PEACH

USPP 9263 Stark Ovation NECTARINE

USPP 9264 Scarlet Sun NECTARINE

USPP 9320 Catalina STRAWBERRY

USPP 9331 Blue Gusto PLUM

USPP 9406 Arctic Gold NECTARINE

USPP 9407 Everthornless BLACKBERRY

USPP 9508 Fuji-Spike APPLE

USPP 9513 September King PLUM

USPP 9541 Crimson Jonagold APPLE

USPP 9568 Murietta PLUM

USPP 9594 Pretty Lady PEACH

USPP 9643 Crystal Belle NECTARINE

USPP 9645 Myra Red Fuji APPLE

USPP 9681 Pacific Gala APPLE

USPP 9707 Lucky Rose Golden APPLE

USPP 9708 Tropic Sweet APPLE

USPP 9757 Aires STRAWBERRY

USPP 9770 Arena STRAWBERRY

USPP 9822 Asio 4 ASIAN PEAR

USPP 9827 Asio 2 ASIAN PEAR

USPP 9828 Asio 3 ASIAN PEAR

USPP 9835 Asio 1 ASIAN PEAR

USPP 9836 Matinee PLUM

USPP 9850 Flamin Fury P.F. 5B PEACH

USPP 9858 Hiromi Red PLUM

USPP 9865 Ralli Seedless GRAPE

USPP 9866 Rosa Linda STRAWBERRY

USPP 9890 Robada APRICOT

USPP 9895 Flamin Fury P.F. 24-007 PEACH

USPP 9916552 GRAPE

USPP 9939 Flamin Fury P.F. 27A PEACH

USPP 9940 Flamin Fury P.F. 25 PEACH

Vallenato MANGO

Van Leuven APPLE

Vandalay CHERRY

Vinegold PEACH

Virginia STRAWBERRY

Waliser APPLE

Waltz APPLE

Washington Spur APPLE

Wimmers Bosc EUROPEAN PEAR 
Wittkopf APPLE

Yadkin BLUEBERRY

Yamaska STRAWBERRY

Yerra Goa MANGO

Zesta APPLE

\section{ADDENDA AND REVISIONS TO PREVIOUS LISTS}

\section{APPLE}

GalaSupreme $^{\mathrm{TM}}$ (Davis).-Corrected spelling (from Galasupreme) and add USPP 10010, issued 1997 (List 36).

SunCrisp $^{\mathrm{TM}}$.-Listed incorrectly as Stark ${ }^{\circledR}$ Suncrisp $^{\mathrm{TM}}$. Description otherwise is accurate (3rd edition of book).

\section{CARAMBOLA}

Golden Star.-Add to description: Open-pollinated seedlings are used for rootstocks. Flowers long-styled (3rd edition of book).

Kary.-Add to description: Planted commercially in south Florida (second most important cultivar after Arkin). Flowers long-styled (3rd edition of book).

\section{CURRANT}

Ben Alder.-USPP 9889 issued 13 May 1997 to Malcolm M. Anderson, Scottish Crop Research Institute, Dundee, Scotland (List 38).

Ben Connan.-USPP 9975 issued 22 July 1997 to Malcolm M. Anderson, Scottish Crop Research Institute, Dundee, Scotland (List $38)$.

\section{PEAR-EUROPEAN}

Harrow Sweet.-USPP 9863 issued 22 Apr. 1997 to Agriculture and Agri-Food Canada, Ontario, Canada (List 36).

\section{PEAR-ROOTSTOCK}

BP-1.-USPP 10231 issued 10 Feb. 1998 to Republic of South Africa Dept. of Agriculture (List 37).

BP-3.-USPP 10307 issued 31 Mar. 1998 to Republic of South Africa Dept. of Agriculture (List 37).

\section{PLUM}

Castleton.-USPP 9638 issued 3 Sept. 1996 (List 36).

\section{WHITE SAPOTE}

Dade.-Add to description: This cultivar probably no longer exists (3rd edition of book).

\section{Previous lists:}

List 38 in HortScience 32(5):785-805 (1997).

List 37 in HortScience 30(6):1135-1150 (1995).

List 36 in HortScience 29(9):942-969 (1994).

List 35 and earlier lists are included in The Brooks and Olmo Register of Fruit \& Nut Varieties, 3rd ed. (1997), ASHS Press. This book also contains a few previously undescribed varieties that later appeared in Lists 36-38. 